Supporting Information for

\title{
Multicolor Photoactivatable Raman probes for Subcellular Imaging and Tracking by Cyclopropenone Caging
}

\author{
Jiajun Du and Lu Wei* \\ Division of Chemistry and Chemical Engineering, California Institute of Technology, Pasadena, \\ California, 91125, United States \\ *To whom correspondence should be addressed. E-mail: 1wei@caltech.edu
}

\section{General Synthesis Experimental Details}

Reagents and solvents from commercial sources were used without further purification unless otherwise stated. All reactions were performed under a $\mathrm{N}_{2}$ atmosphere unless specified otherwise. All reaction flasks were flame dried. Column chromatography was carried out using SiliaFlash irregular silica gel P60 (Silicycle, 40 - $63 \mu \mathrm{m}, 60 \AA$ ). Thin layer chromatography (TLC) was carried out with Millipore silica gel F-254 plates, and plates were visualized using UV light or $\mathrm{KMnO}_{4}$ stain. The UV handlamp is an Analytik Jena UVP EL Series Lamp (UVLS-24, 4 Watt, 2UV 254/365 nm).

NMR spectra were recorded using a $400 \mathrm{MHz}$ Bruker Avance III HD with Prodigy Cryoprobe or a $400 \mathrm{MHz}$ Bruker Avance Neo. All 1H NMR spectra are reported in $\delta$ units, parts per million (ppm), and were measured relative to the signals for $\mathrm{CH}_{2} \mathrm{Cl}_{2}(5.32 \mathrm{ppm})$ in deuterated solvent. All ${ }^{13} \mathrm{C}$ NMR spectra were measured in deuterated solvents and are reported in ppm relative to the signals for ${ }^{13} \mathrm{CD}_{2} \mathrm{Cl}_{2}(54.00 \mathrm{ppm})$. Multiplicity and qualifier abbreviations are as follows: $\mathrm{s}=$ singlet, $\mathrm{d}=$ doublet, $\mathrm{t}=$ triplet, $\mathrm{q}=$ quartet, $\mathrm{m}=$ multiplet, $\mathrm{br}=$ broad.

High resolution mass spectra (HRMS) were obtained from an LTQ linear ion trap mass spectrometer with liquid-chromatography (LC) system (Thermo) or LCT Premier XE electrospray TOF mass spectrometer with UPLC (Waters).

Preparative HPLC was performed on an Agilent 1100 Series semi-preparative HPLC apparatus using Eclipse XDB-C18 $9.4 \times 250 \mathrm{~mm}$ column with water $(0.1 \% \mathrm{AcOH})$ and acetonitrile as mobile phases. UV-Vis absorption spectra were recorded on a Varian Cary $50 \mathrm{UV}-\mathrm{V}$ is Spectrophotometer (Agilent). Analytical HPLC coupled with mass spectrometry (LC-MS) was performed on Agilent 1290 infinity LC system using ZORBAX RRHD Eclipse Plus C18, 95A, 2.1 x 50 mm, $1.8 \mu \mathrm{m}$ column with an Agilent 6140 Series Quadrupole LCMS / LC-MS / MSD / Mass Spectrometer System. The mobile phase is water $(0.1 \% \mathrm{AcOH})$ and acetonitrile with running method of gradient $5 \%-95 \%$ acetonitrile ( $1 \mathrm{ml} / \mathrm{min}, 0-4 \mathrm{~min})$. Mass spectrometry detection region ranges from 100 to 800 AMU. 


\section{2-phenyl-3-(phenylethynyl)cycloprop-2-en-1-one (2-cyclo, 3)}

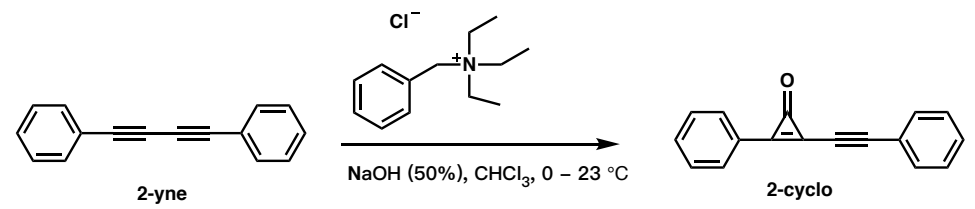

The synthesis procedure of 2-cyclo (3) was adapted from literature report ${ }^{1}$. To a vigorously stirred mixture of 2-yne (4, $202 \mathrm{mg}, 1 \mathrm{mmol})$ and benzyltriethylammonium chloride (114 mg, $0.5 \mathrm{mmol})$ in chloroform $(8 \mathrm{~mL})$, which had been cooled with an ice bath, was added $10 \mathrm{~g}$ of $50 \% \mathrm{aq}$. $\mathrm{NaOH}$ (w/w, $125 \mathrm{mmol}$ ) dropwise. Afterwards, the ice bath was removed and the solution was stirred for 40 minutes at $23{ }^{\circ} \mathrm{C}$. The reaction was monitored by TLC (1:3, EtOAc : Hexane). The resulting mixture was then separated, and the aqueous layer extracted with DCM. The combined organic layers were washed with saturated $\mathrm{NaHCO}_{3}$ and brine, dried over anhydrous $\mathrm{Na}_{2} \mathrm{SO}_{4}$, and evaporated. The crude product was purified by flash column chromatography with EtOAc : Hexane (1:5) as eluents. 2-cyclo (4) was isolated as yellow solid (74 mg, $0.32 \mathrm{mmol}, 32 \%)$ and unreacted 2-yne (3) was also recovered (91 $\mathrm{mg}, 0.45 \mathrm{mmol}, 45 \%)$.

${ }^{1} \mathrm{H}$ NMR (400 MHz, $\left.\mathrm{CD}_{2} \mathrm{Cl}_{2}\right) \delta: 7.93(\mathrm{~m}, 2 \mathrm{H}), 7.62(\mathrm{~m}, 5 \mathrm{H}), 7.47(\mathrm{~m}, 3 \mathrm{H})$.

${ }^{13} \mathrm{C}\left\{{ }^{1} \mathrm{H}\right\}$ NMR $\left(100 \mathrm{MHz}, \mathrm{CD}_{2} \mathrm{Cl}_{2}\right) \delta 153.02,151.18,137.32,133.90,133.25,131.53,131.44$, 129.89, 129.31, 124.30, 121.25, 108.77, 74.32.

HRMS $\left(\mathrm{FAB}^{+}, \mathrm{m} / \mathrm{z}\right)$ : calcd. for $\left[\mathrm{C}_{17} \mathrm{H}_{11} \mathrm{O}\right]^{+}(\mathrm{M}+\mathrm{H})^{+}, 231.0810$; found, 231.0838.

(3-(4-(3-oxo-2-phenylcycloprop-1-en-1-yl)phenoxy)propyl)triphenylphosphonium bromide (Cyclo-Mito, 7) and 2-(4-(2-(2-((6-chlorohexyl)oxy)ethoxy)ethoxy)phenyl)-3phenylcycloprop-2-en-1-one (Cyclo-LD, 17)

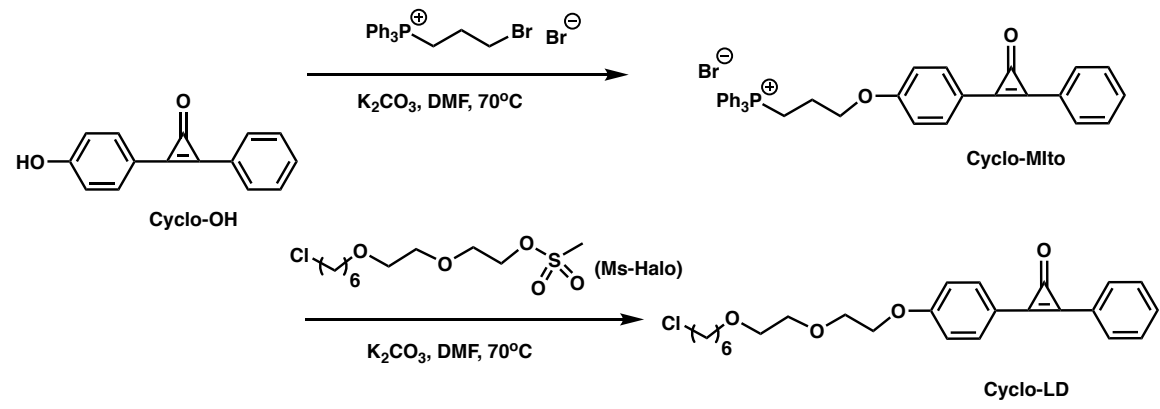

Cyclo-OH and Ms-Halo were produced according to literature ${ }^{2,3}$.

Cyclo-OH (22 mg, $0.1 \quad \mathrm{mmol}), \quad \mathrm{K}_{2} \mathrm{CO}_{3} \quad(28 \quad \mathrm{mg}, \quad 0.2 \quad \mathrm{mmol})$ and (3Bromopropyl)triphenylphosphonium bromide (139 mg, $0.3 \mathrm{mmol}$ ) or Ms-Halo (45 mg, $0.15 \mathrm{mmol})$ were stirred in $3 \mathrm{ml} \mathrm{DMF}$ at $70{ }^{\circ} \mathrm{C}$ for 1 hour. Then the reaction solution was filtered and quenched with saturated $\mathrm{NH}_{4} \mathrm{Cl}$ solution. The solution was extracted by EtOAc and concentrated. The crude products were dissolved in acetonitrile and subjected to reverse phase prep-HPLC for separation to obtain Cyclo-Mito (7, $36 \mathrm{mg}, 0.059 \mathrm{mmol}, 59 \%)$ and Cyclo-LD (17, $29 \mathrm{mg}, 0.068 \mathrm{mmol}, 68 \%)$ as pale white solids. The products would decompose to Cyclo-OH on silica gel. 
Cyclo-Mito (7). ${ }^{1} \mathrm{H}$ NMR $\left(400 \mathrm{MHz}, \mathrm{CD}_{2} \mathrm{Cl}_{2}\right) \delta 7.95-7.78(\mathrm{~m}, 13 \mathrm{H}), 7.70(\mathrm{td}, J=8.0,3.4 \mathrm{~Hz}$, $6 \mathrm{H}), 7.57$ (ddt, $J=5.7,4.0,2.3 \mathrm{~Hz}, 3 \mathrm{H}), 7.15-7.05(\mathrm{~m}, 2 \mathrm{H}), 4.42(\mathrm{t}, J=5.8 \mathrm{~Hz}, 2 \mathrm{H}), 4.08-3.87$ $(\mathrm{m}, 2 \mathrm{H}), 2.20(\mathrm{~m}, 2 \mathrm{H})$

HRMS (ESI, m/z): calcd. for $\left[\mathrm{C}_{36} \mathrm{H}_{30} \mathrm{O}_{2} \mathrm{P}\right]^{+}\left(\mathrm{M}^{+}\right)$, 525.1978; found, 525.1960.

Cyclo-LD (17). ${ }^{1} \mathrm{H}$ NMR $\left(400 \mathrm{MHz}, \mathrm{CD}_{2} \mathrm{Cl}_{2}\right) \delta 8.01-7.90(\mathrm{~m}, 4 \mathrm{H}), 7.59(\mathrm{dp}, \mathrm{J}=6.2,2.0 \mathrm{~Hz}, 3 \mathrm{H})$, $7.17-7.05(\mathrm{~m}, 2 \mathrm{H}), 4.29-4.17(\mathrm{~m}, 2 \mathrm{H}), 3.89-3.82(\mathrm{~m}, 2 \mathrm{H}), 3.70-3.64(\mathrm{~m}, 2 \mathrm{H}), 3.61-3.49$ $(\mathrm{m}, 4 \mathrm{H}), 3.44(\mathrm{t}, \mathrm{J}=6.6 \mathrm{~Hz}, 2 \mathrm{H}), 1.86-1.71(\mathrm{~m}, 2 \mathrm{H}), 1.62-1.51(\mathrm{~m}, 2 \mathrm{H}), 1.50-1.29(\mathrm{~m}, 4 \mathrm{H})$. ${ }^{13} \mathrm{C}\left\{{ }^{1} \mathrm{H}\right\}$ NMR $\left(100 \mathrm{MHz}, \mathrm{CD}_{2} \mathrm{Cl}_{2}\right) \delta 162.78,155.47,148.26,145.02,134.14,132.55,131.52$, $129.70,124.82,117.43,115.68,71.54,71.28,70.52,69.77,68.35,45.64,33.00,29.94,27.09$, 25.84 .

HRMS (ESI, m/z): calcd. for $\left[\mathrm{C}_{25} \mathrm{H}_{30} \mathrm{O}_{4} \mathrm{Cl}\right]^{+}(\mathrm{M}+\mathrm{H})^{+}$, 429.1833; found, 429.1845 .

\section{2-(4-hydroxy-2,6-dimethylphenyl)-3-mesitylcycloprop-2-en-1-one (Me-1-cyclo-OH or Me- OH or 8)}

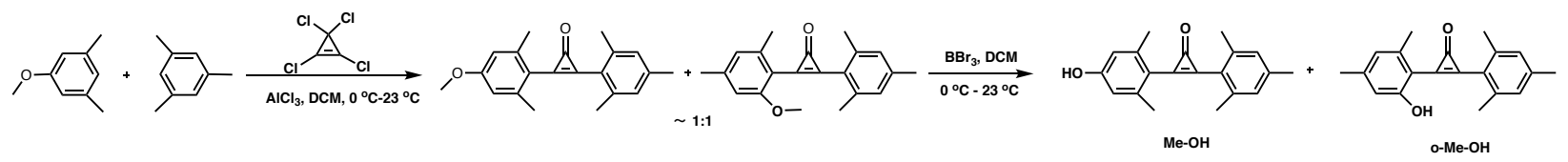

$\mathrm{Me}-\mathrm{OH}(8)$ was produced following procedures modified from a previous report ${ }^{2}$. In a flask, $\mathrm{AlCl}_{3}$ (1.49 g, $11.2 \mathrm{mmol}$ ) was charged to $10 \mathrm{ml}$ dry DCM. The flask was then cooled to $0{ }^{\circ} \mathrm{C}$. To the stirring suspension, tetrachlorocyclopropene $(500 \mathrm{mg}, 2.8 \mathrm{mmol})$ was added dropwise. The resulting suspension was allowed to stir at $0{ }^{\circ} \mathrm{C}$ for 10 minutes. Then mesitylene $(336 \mathrm{mg}, 2.8$ mmol) was added and this solution was stirred at $0{ }^{\circ} \mathrm{C}$ for 90 minutes. To this stirring suspension, 3,5-Dimethylanisole $(381 \mathrm{mg}, 2.8 \mathrm{mmol})$ was added. Then the solution was allowed to warm to $23{ }^{\circ} \mathrm{C}$ and reacted for 1 hour. This reaction was monitored by TLC (1:3, EtOAc : Hexane). After reaction, at $0{ }^{\circ} \mathrm{C}$ the suspension was quenched slowly with saturated $\mathrm{NH}_{4} \mathrm{Cl}$ solution, extracted with DCM, washed with brine and dried over anhydrous $\mathrm{Na}_{2} \mathrm{SO}_{4}$. The organic phase was concentrated, and subjected to column chromatography with EtOAc : Hexane (1:5) as eluents. The obtained cyclopropenone products $(703 \mathrm{mg}, 2.3 \mathrm{mmol}, 82 \%)$ were a mixture of ortho- and parasubstituted isomers ( 1:1, identified by LC-MS). The two isomers were very close on TLC and column and hard to be separated. The isomers were separated at later step.

The obtained cyclopropenone isomers $(306 \mathrm{mg}, 1 \mathrm{mmol})$ were dissolved in $5 \mathrm{ml}$ dry DCM in a flask. The flask was then cooled to $0{ }^{\circ} \mathrm{C}$. To the stirring suspension, $1 \mathrm{M} \mathrm{BBr}_{3}$ in $\mathrm{DCM}(2.5 \mathrm{ml}, 2.5$ mmol) was added dropwise. The stirred solution was kept at $0{ }^{\circ} \mathrm{C}$ for 1 hour, then allowed to warm to $23{ }^{\circ} \mathrm{C}$ and reacted overnight. After reaction, at $0{ }^{\circ} \mathrm{C}$ the suspension was quenched slowly with saturated $\mathrm{NH}_{4} \mathrm{Cl}$ solution, extracted with DCM, washed with brine and dried over anhydrous $\mathrm{Na}_{2} \mathrm{SO}_{4}$. The organic phase was concentrated, and subjected to column chromatography with EtOAc: Hexane (1:2) as eluents to obtain Me-OH (7, $132 \mathrm{mg}, 0.45 \mathrm{mmol})$ and o-Me-OH (120 mg, $0.41 \mathrm{mmol})$ as pale white solids. Note that these two isomers should be carefully separated on a 
long column, and these solid cyclopropenones have pleasant fragrance similar to that of banana shrub flowers.

Me-OH (8): ${ }^{1} \mathrm{H}$ NMR (400 MHz, $\mathrm{CD}_{2} \mathrm{Cl}_{2}$ with $\mathrm{CD}_{3} \mathrm{OD}$ as co-solvent) $\delta 6.90(\mathrm{~d}, \mathrm{~J}=1.1 \mathrm{~Hz}, 2 \mathrm{H})$, $6.53(\mathrm{~s}, 2 \mathrm{H}), 4.31(\mathrm{br}, 1 \mathrm{H}), 2.25-2.22(\mathrm{~s}, 3 \mathrm{H}), 2.21-2.18(\mathrm{~s}, 6 \mathrm{H}), 2.18-2.15(\mathrm{~s}, 6 \mathrm{H})$.

${ }^{13} \mathrm{C}\left\{{ }^{1} \mathrm{H}\right\}$ NMR (100 MHz, $\mathrm{CD}_{2} \mathrm{Cl}_{2}$ with $\mathrm{CD}_{3} \mathrm{OD}$ as co-solvent) $\delta 162.10,160.00,151.88,148.49$, $143.89,142.59,139.48,129.32,124.48,117.37,115.82,21.30,20.91,20.50$.

HRMS (ESI, m/z): calcd. for $\left[\mathrm{C}_{20} \mathrm{H}_{21} \mathrm{O}_{2}\right]^{+}(\mathrm{M}+\mathrm{H})^{+}, 293.1537$; found, 293.1539.

o-Me-OH: ${ }^{1} \mathrm{H}$ NMR (400 MHz, DMSO-d 6 ) $\delta 10.27$ (br, 1H), 6.99 (s, 2H), 6.67 (s, 1H), 6.62 (s, $1 \mathrm{H}), 2.44(\mathrm{~s}, 3 \mathrm{H}), 2.33-2.23(\mathrm{~m}, 12 \mathrm{H})$.

HRMS (ESI, m/z): calcd. for $\left[\mathrm{C}_{36} \mathrm{H}_{30} \mathrm{O}_{2} \mathrm{P}\right]^{+}\left(\mathrm{M}^{+}\right)$, 293.1537; found, 293.1537.
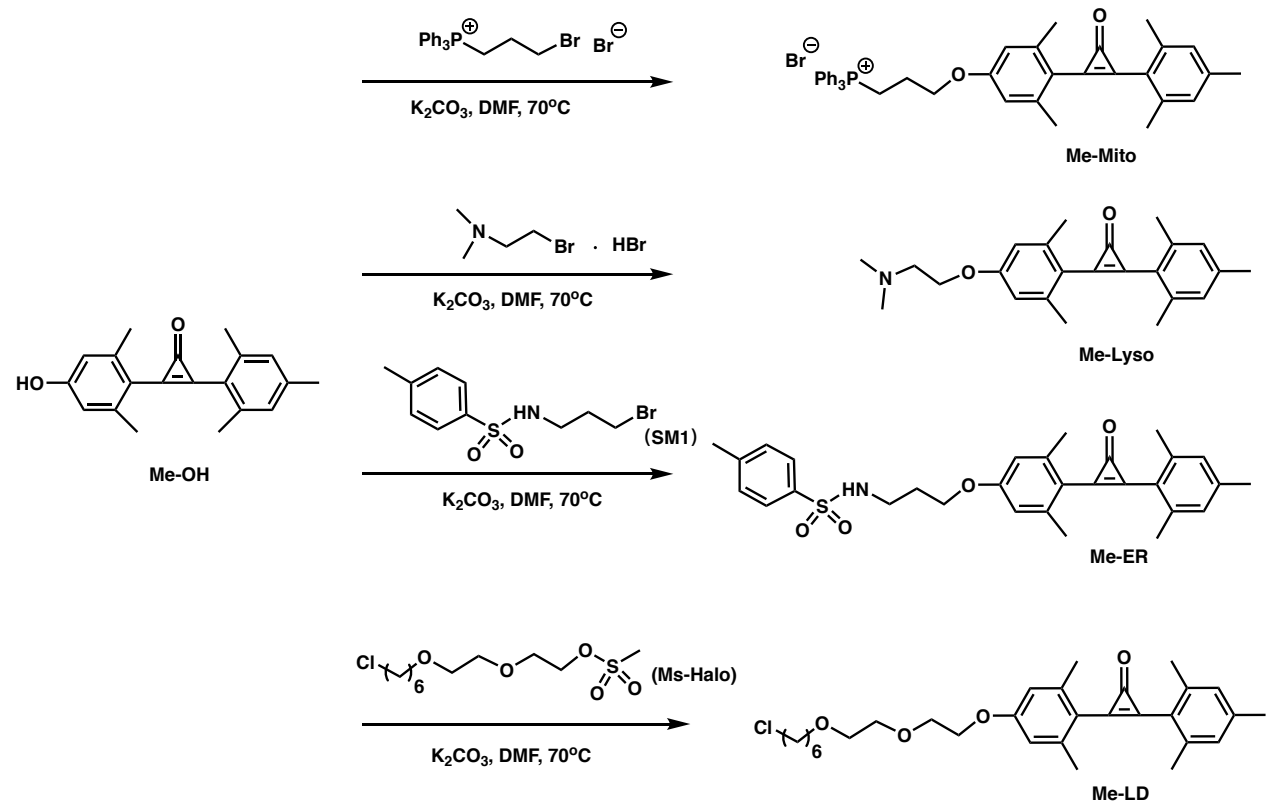

\section{(3-(4-(2-mesityl-3-oxocycloprop-1-en-1-yl)-3,5- dimethylphenoxy)propyl)triphenylphosphonium bromide (Me-Mito, 12)}

Me-OH (8, $29 \quad \mathrm{mg}, \quad 0.1 \quad \mathrm{mmol}), \quad \mathrm{K}_{2} \mathrm{CO}_{3} \quad(28 \quad \mathrm{mg}, \quad 0.2 \quad \mathrm{mmol})$ and (3Bromopropyl)triphenylphosphonium bromide (139 $\mathrm{mg}, 0.3 \mathrm{mmol}$ ) were stirred in $3 \mathrm{ml} \mathrm{DMF}$ at $70{ }^{\circ} \mathrm{C}$ for 1 hour. Then the reaction solution was filtered and quenched with saturated $\mathrm{NH}_{4} \mathrm{Cl}$ solution. The solution was extracted by EtOAc and concentrated. The crude product was subjected to column chromatography with $(\mathrm{MeOH}+\mathrm{AcOH})$ in $\mathrm{DCM}(10 \%+2.5 \%)$ as eluents to obtain MeMito (12, $44 \mathrm{mg}, 0.065 \mathrm{mmol}, 65 \%)$ as pale white solid.

${ }^{1} \mathrm{H}$ NMR (400 MHz, $\left.\mathrm{CD}_{2} \mathrm{Cl}_{2}\right) \delta 7.89-7.79(\mathrm{~m}, 9 \mathrm{H}), 7.75-7.68(\mathrm{~m}, 6 \mathrm{H}), 6.98(\mathrm{~s}, 2 \mathrm{H}), 6.70(\mathrm{~s}$, $2 \mathrm{H}), 4.39-4.31(\mathrm{~m}, 2 \mathrm{H}), 3.95(\mathrm{~m}, 2 \mathrm{H}), 2.38-2.25(\mathrm{~m}, 15 \mathrm{H}), 2.22-2.15(\mathrm{~m}, 2 \mathrm{H})$.

${ }^{13} \mathrm{C}\left\{{ }^{1} \mathrm{H}\right\}$ NMR $\left(100 \mathrm{MHz}, \mathrm{CD}_{2} \mathrm{Cl}_{2}\right) \delta 161.20,158.11,151.85,150.56,142.77,142.05,139.44$, $135.71,134.33,134.23,131.06,130.94,129.12,124.59,119.91,119.04,118.18,114.44,67.26$, 67.09, 23.27, 21.67, 21.26, 20.83, 20.65, 20.12. 
HRMS (ESI, m/z): calcd. for $\left[\mathrm{C}_{41} \mathrm{H}_{40} \mathrm{O}_{2} \mathrm{P}\right]^{+}\left(\mathrm{M}^{+}\right)$, 595.2761; found, 595.2755.

2-(4-(2-(dimethylamino)ethoxy)-2,6-dimethylphenyl)-3-mesitylcycloprop-2-en-1-one (MeLyso, 13)

Me-OH (8, $29 \mathrm{mg}, 0.1 \mathrm{mmol}), \mathrm{K}_{2} \mathrm{CO}_{3}(41 \mathrm{mg}, 0.3 \mathrm{mmol})$ and 2-bromo-N,N-dimethylethanamine hydrobromide ( $46 \mathrm{mg}, 0.2 \mathrm{mmol}$ ) were stirred in $3 \mathrm{ml} \mathrm{DMF}$ at $70{ }^{\circ} \mathrm{C}$ for 1 hour. Then the reaction solution was filtered and quenched with saturated $\mathrm{NH}_{4} \mathrm{Cl}$ solution. The solution was extracted by EtOAc and concentrated. The crude product was subjected to column chromatography with $7 \%$ $\mathrm{MeOH}$ in DCM as eluents to obtain Me-Lyso (13, $28 \mathrm{mg}, 0.076 \mathrm{mmol}, 76 \%)$ as pale white solid.

${ }^{1} \mathrm{H}$ NMR $\left(400 \mathrm{MHz}, \mathrm{CD}_{2} \mathrm{Cl}_{2}\right) \delta 6.98(\mathrm{~s}, 2 \mathrm{H}), 6.70(\mathrm{~s}, 2 \mathrm{H}), 4.11(\mathrm{t}, J=5.7 \mathrm{~Hz}, 2 \mathrm{H}), 2.75(\mathrm{t}, J=5.7$ $\mathrm{Hz}, 2 \mathrm{H}), 2.36-2.31(\mathrm{~m}, 15 \mathrm{H}), 2.28(\mathrm{~s}, 6 \mathrm{H})$.

${ }^{13} \mathrm{C}\left\{{ }^{1} \mathrm{H}\right\}$ NMR $\left(100 \mathrm{MHz}, \mathrm{CD}_{2} \mathrm{Cl}_{2}\right) \delta 161.84,158.08,152.04,150.29,142.82,141.91,139.36$, $129.10,124.77,119.51,114.39,66.57,58.53,46.04,21.67,21.31,20.83$.

HRMS (ESI, m/z): calcd. for $\left[\mathrm{C}_{24} \mathrm{H}_{29} \mathrm{NO}_{2}\right]^{+}(\mathrm{M}+\mathrm{H})^{+}, 364.2272$; found, 364.2279 .

\section{$N$-(3-(4-(2-mesityl-3-oxocycloprop-1-en-1-yl)-3,5-dimethylphenoxy)propyl)-4- methylbenzenesulfonamide (Me-ER, 14)}

SM1 was produced according to literature ${ }^{4}$.

$\mathrm{Me}-\mathrm{OH}(\mathbf{8}, 29 \mathrm{mg}, 0.1 \mathrm{mmol}), \mathrm{K}_{2} \mathrm{CO}_{3}(28 \mathrm{mg}, 0.2 \mathrm{mmol})$ and SM1 ( $\left.88 \mathrm{mg}, 0.3 \mathrm{mmol}\right)$ were stirred in $3 \mathrm{ml} \mathrm{DMF}$ at $70{ }^{\circ} \mathrm{C}$ for 1 hour. Then the reaction solution was filtered and quenched with saturated $\mathrm{NH}_{4} \mathrm{Cl}$ solution. The solution was extracted by EtOAc and concentrated. The crude product was subjected to column chromatography with EtOAc : Hexane (1:1.5) as eluents to obtain Me-ER (14, $32 \mathrm{mg}, 0.064 \mathrm{mmol}, 64 \%)$ as pale white solid.

${ }^{1} \mathrm{H}$ NMR (400 MHz, $\left.\mathrm{CD}_{2} \mathrm{Cl}_{2}\right) \delta 7.72(\mathrm{~d}, J=8.2 \mathrm{~Hz}, 2 \mathrm{H}), 7.29(\mathrm{~d}, J=8.2 \mathrm{~Hz}, 2 \mathrm{H}), 6.98(\mathrm{~s}, 2 \mathrm{H})$, $6.63(\mathrm{~s}, 2 \mathrm{H}), 4.94(\mathrm{t}, J=6.2 \mathrm{~Hz}, 1 \mathrm{H}), 4.00(\mathrm{t}, J=5.6 \mathrm{~Hz}, 2 \mathrm{H}), 3.20-3.06(\mathrm{~m}, 2 \mathrm{H}), 2.40(\mathrm{~s}, 3 \mathrm{H})$, $2.37-2.30(\mathrm{~m}, 9 \mathrm{H}), 2.28(\mathrm{~s}, 6 \mathrm{H}), 1.94(\mathrm{p}, J=6.2 \mathrm{~Hz}, 2 \mathrm{H})$.

${ }^{13} \mathrm{C}\left\{{ }^{1} \mathrm{H}\right\}$ NMR $\left(100 \mathrm{MHz}, \mathrm{CD}_{2} \mathrm{Cl}_{2}\right) \delta 161.62,158.12,151.92,150.39,144.15,142.78,141.99$, $139.38,137.48,130.24,129.12,127.53,124.68,119.63,114.33,65.97,41.16,29.64,21.79,21.67$, $21.29,20.84$.

HRMS (ESI, m/z): calcd. for $\left[\mathrm{C}_{30} \mathrm{H}_{34} \mathrm{NO}_{4} \mathrm{~S}\right]^{+}(\mathrm{M}+\mathrm{H})^{+}, 504.2204$; found, 504.2207.

2-(4-(2-(2-((6-chlorohexyl)oxy)ethoxy)ethoxy)-2,6-dimethylphenyl)-3-mesitylcycloprop-2en-1-one (Me-LD, 15)

Me-OH (8, $29 \mathrm{mg}, 0.1 \mathrm{mmol}), \mathrm{K}_{2} \mathrm{CO}_{3}(41 \mathrm{mg}, 0.3 \mathrm{mmol})$ and Ms-Halo $(60 \mathrm{mg}, 0.2 \mathrm{mmol})$ were stirred in $3 \mathrm{ml} \mathrm{DMF}$ at $70{ }^{\circ} \mathrm{C}$ for 4 hours. Then the reaction solution was filtered and quenched 
with saturated $\mathrm{NH}_{4} \mathrm{Cl}$ solution. The solution was extracted by EtOAc and concentrated. The crude product was subjected to column chromatography with EtOAc : Hexane (1:2) as eluents to obtain Me-LD (15, $35 \mathrm{mg}, 0.070 \mathrm{mmol}, 70 \%)$.

${ }^{1} \mathrm{H}$ NMR $\left(400 \mathrm{MHz}, \mathrm{CD}_{2} \mathrm{Cl}_{2}\right) \delta 6.97(\mathrm{~s}, 2 \mathrm{H}), 6.71(\mathrm{~s}, 2 \mathrm{H}), 4.19-4.11(\mathrm{~m}, 2 \mathrm{H}), 3.87-3.78(\mathrm{~m}$, $2 \mathrm{H}), 3.68-3.63(\mathrm{~m}, 2 \mathrm{H}), 3.59-3.50(\mathrm{~m}, 4 \mathrm{H}), 3.44(\mathrm{t}, J=6.6 \mathrm{~Hz}, 2 \mathrm{H}), 2.33(\mathrm{~d}, J=2.0 \mathrm{~Hz}, 9 \mathrm{H})$, $2.28(\mathrm{~s}, 6 \mathrm{H}), 1.76(\mathrm{dq}, J=8.1,6.7 \mathrm{~Hz}, 2 \mathrm{H}), 1.60-1.53(\mathrm{~m}, 2 \mathrm{H}), 1.48-1.35(\mathrm{~m}, 4 \mathrm{H})$.

${ }^{13} \mathrm{C}\left\{{ }^{1} \mathrm{H}\right\}$ NMR $\left(100 \mathrm{MHz}, \mathrm{CD}_{2} \mathrm{Cl}_{2}\right) \delta 161.83,158.09,152.01,150.36,142.80,141.93,139.38$, $129.10,124.74,119.61,114.42,71.70,71.39$, 70.69, 70.03, 68.11, 45.80, 33.17, 30.10, 27.26, 26.00, 21.67, 21.31, 20.83.

HRMS (ESI, m/z): calcd. for $\left[\mathrm{C}_{30} \mathrm{H}_{40} \mathrm{ClO}_{4}\right]^{+}(\mathrm{M}+\mathrm{H})^{+}, 499.2610$; found, 499.2620 .

(3-(4-(2-mesityl-3-oxocycloprop-1-en-1-yl-1,2-13C2)-3,5dimethylphenoxy)propyl)triphenylphosphonium bromide (Me-Mito- $\left.{ }^{13} \mathrm{C}, 16\right)$
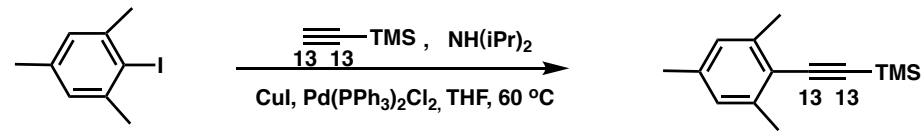

11

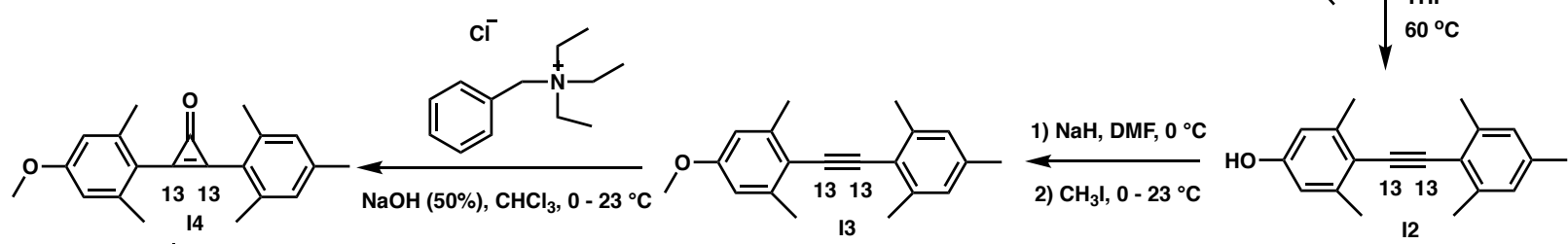

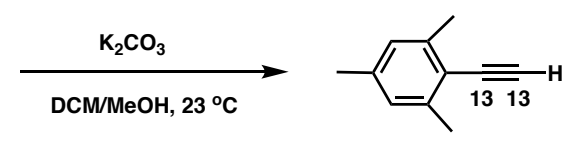

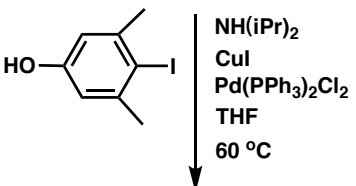

2) $\mathrm{CH}_{3} \mathrm{l}, 0-23^{\circ} \mathrm{C}$ $\mathrm{BBr}_{3}\left\lfloor\begin{array}{l}\mathrm{DCM} \\ 23^{\circ} \mathrm{C}\end{array}\right.$

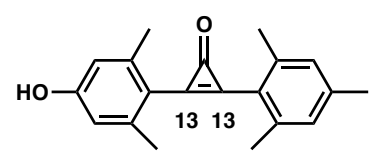

15

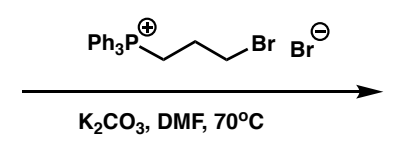

$\mathrm{K}_{2} \mathrm{CO}_{3}, \mathrm{DMF}, 70^{\circ} \mathrm{C}$

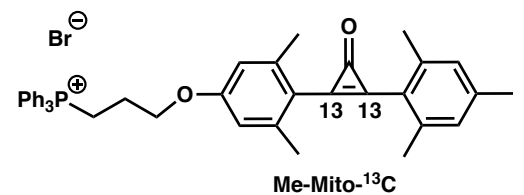

2-Iodo-1,3,5-trimethylbenzene (246 mg, $1 \mathrm{mmol}$ ), (trimethylsilyl)acetylene- ${ }^{13} \mathrm{C}_{2}$ (Sigma 603511 , $100 \mathrm{mg}, 1 \mathrm{mmol})$, copper(I) iodide (10 mg, $0.05 \mathrm{mmol})$, bis(triphenylphosphine)palladium(II) dichloride (35 mg, $0.05 \mathrm{mmol}$ ) were dissolved in THF ( $5 \mathrm{ml})$. The mixture was degassed and filled with nitrogen. Then diisopropylamine $(202 \mathrm{mg}, 2 \mathrm{mmol})$ was added and the black suspension was heated to $60{ }^{\circ} \mathrm{C}$ and stirred for 2 hours. After the reaction was finished, the reaction solution was filtered and quenched with $1 \mathrm{M} \mathrm{HCl}$. Then the solution was extracted by EtOAc and hexane. The organic phase was washed with brine, dried over anhydrous $\mathrm{Na}_{2} \mathrm{SO}_{4}$ and subjected to column chromatography with pure hexane as eluent to obtain I1 (157 mg, $0.72 \mathrm{mmol}, 72 \%$ ) as yellow oil. 
I1. ${ }^{1} \mathrm{H}$ NMR (400 MHz, $\left.\mathrm{CD}_{2} \mathrm{Cl}_{2}\right) \delta 6.87(\mathrm{~s}, 2 \mathrm{H}), 2.39(\mathrm{~s}, 6 \mathrm{H}), 2.28(\mathrm{~s}, 3 \mathrm{H}), 0.28(\mathrm{dd}, J=2.3,0.7$ $\mathrm{Hz}, 9 \mathrm{H})$.

${ }^{13} \mathrm{C}\left\{{ }^{1} \mathrm{H}\right\} \operatorname{NMR}\left(100 \mathrm{MHz}, \mathrm{CD}_{2} \mathrm{Cl}_{2}\right) \delta 141.01,128.03,104.46,103.13,102.72,101.38,21.65,21.21$, 0.48 .

To a solution of I1 (109 mg, $0.5 \mathrm{mmol})$ in DCM-MeOH $(1: 1,4 \mathrm{~mL})$ was added $\mathrm{K}_{2} \mathrm{CO}_{3}(276 \mathrm{mg}$, $2 \mathrm{mmol}$ ). After the mixture was stirred at $23{ }^{\circ} \mathrm{C}$ for 2 hours, $\mathrm{H}_{2} \mathrm{O}$ was added and the mixture was extracted with EtOAc. The organic phase was washed with brine, dried over anhydrous $\mathrm{Na}_{2} \mathrm{SO}_{4}$ to obtain the product without further purification.

The whole products obtained in the last step, 4-Iodo-2,6-dimethylphenol (124mg, $0.5 \mathrm{mmol})$, copper(I) iodide (5 mg, $0.026 \mathrm{mmol}$ ), bis(triphenylphosphine)palladium(II) dichloride (18 $\mathrm{mg}$, $0.025 \mathrm{mmol}$ ) were dissolved in THF $(3 \mathrm{ml})$. The mixture was degassed and filled with nitrogen. Then diisopropylamine (101 mg, $1 \mathrm{mmol})$ was added and the black suspension was heated to $60^{\circ} \mathrm{C}$ and stirred for 2 hours. After the reaction was finished, the reaction solution was filtered and quenched with $1 \mathrm{M} \mathrm{HCl}$. Then the solution was extracted by EtOAc and hexane. The organic phase was washed with brine, dried over anhydrous $\mathrm{Na}_{2} \mathrm{SO}_{4}$ and subjected to column chromatography with EtOAc : hexane (1:2) as eluent to obtain $\mathbf{I} 2(98 \mathrm{mg}, 0.37 \mathrm{mmol}, 74 \%$, over two steps) as white solids.

${ }^{1} \mathrm{H}$ NMR $\left(400 \mathrm{MHz}, \mathrm{CD}_{2} \mathrm{Cl}_{2}\right) \delta 7.45-7.35(\mathrm{~m}, 1 \mathrm{H}), 6.92(\mathrm{~s}, 2 \mathrm{H}), 6.59(\mathrm{~s}, 2 \mathrm{H}), 2.48(\mathrm{~d}, J=3.6 \mathrm{~Hz}$, $12 \mathrm{H}), 2.29$ (s, 3H).

${ }^{13} \mathrm{C}\left\{{ }^{1} \mathrm{H}\right\}$ NMR $\left(100 \mathrm{MHz}, \mathrm{CD}_{2} \mathrm{Cl}_{2}\right) \delta 155.87,142.56,140.16,137.91,128.16,114.47,97.07,95.30$, 95.17, 93.40, 21.99, 21.84, 21.58 .

I2 (98 mg, $0.37 \mathrm{mmol})$ was dissolved in DMF $(2 \mathrm{ml})$ and cooled to $0{ }^{\circ} \mathrm{C}$. $\mathrm{NaH}(12 \mathrm{mg}, 0.5 \mathrm{mmol})$ was added to the stirred solution. Stirring was maintained for 30 minutes at $0{ }^{\circ} \mathrm{C}$. Then the mixture was added iodomethane ( $105 \mathrm{mg}, 0.74 \mathrm{mmol}$, dissolved in $1 \mathrm{ml} \mathrm{DMF}$ ) and allowed to warm up to $23^{\circ} \mathrm{C}$ and stirred for 2 hours. Then the mixture was poured over water and extracted with EtOAc. The organic phase was washed with brine, dried over anhydrous $\mathrm{Na}_{2} \mathrm{SO}_{4}$ to obtain the product $\mathbf{I 3}$ without further purification.

All the product $\mathbf{I} 3$ obtained in the last step was dissolved in chloroform $(4 \mathrm{~mL})$ and added with benzyltriethylammonium chloride $(68 \mathrm{mg}, 0.3 \mathrm{mmol})$. Then the mixture was cooled with an ice bath, and was added $3 \mathrm{~g}$ of $50 \% \mathrm{NaOH}(37.5 \mathrm{mmol})$ dropwise. After adding $\mathrm{NaOH}$, ice bath was removed and let the solution be stirred for 1 hour at $23{ }^{\circ} \mathrm{C}$. The reaction was monitored by TLC $(1: 3$, EtOAc : Hexane). The resulting mixture was then separated, and the aqueous layer extracted with DCM. The combined organic layers were washed with saturated $\mathrm{NaHCO}_{3}$ and brine, dried over anhydrous $\mathrm{Na}_{2} \mathrm{SO}_{4}$, and evaporated. The crude product was purified by flash column chromatography with EtOAc : Hexane (1:5) as eluents to obtain the product I4 (65 mg, $0.21 \mathrm{mmol}$, $57 \%$, over two steps) as white solid.

I4. ${ }^{1} \mathrm{H}$ NMR (400 MHz, $\left.\mathrm{CD}_{2} \mathrm{Cl}_{2}\right) \delta 6.98(\mathrm{~s}, 2 \mathrm{H}), 6.70(\mathrm{~s}, 2 \mathrm{H}), 3.83(\mathrm{~s}, 3 \mathrm{H}), 2.34(\mathrm{~s}, 9 \mathrm{H}), 2.28(\mathrm{~s}$, $6 \mathrm{H})$.

${ }^{13} \mathrm{C}$ NMR $\left(100 \mathrm{MHz}, \mathrm{CD}_{2} \mathrm{Cl}_{2}\right) \delta 152.16,151.95,150.35,150.13$ (The highest four peaks). 
The obtained $\mathbf{I} 4(65 \mathrm{mg}, 0.21 \mathrm{mmol})$ were dissolved in $2 \mathrm{ml}$ dry DCM in a flask. The flask was then cooled to $0{ }^{\circ} \mathrm{C}$. To the stirring suspension, $1 \mathrm{M} \mathrm{BBr} 3$ in $\mathrm{DCM}(0.5 \mathrm{ml}, 0.5 \mathrm{mmol})$ was added dropwise. The stirred solution was kept at $0{ }^{\circ} \mathrm{C}$ for 1 hour, then allowed to warm to $23{ }^{\circ} \mathrm{C}$ and reacted overnight. After reaction, at $0{ }^{\circ} \mathrm{C}$ the suspension was quenched slowly with saturated $\mathrm{NH}_{4} \mathrm{Cl}$ solution, extracted with DCM, washed with brine and dried over anhydrous $\mathrm{Na}_{2} \mathrm{SO}_{4}$. The obtained product $\mathbf{I 5}$ was used without further purification.

The product $\mathbf{I 5}, \mathrm{K}_{2} \mathrm{CO}_{3}(56 \mathrm{mg}, 0.4 \mathrm{mmol}$ ) and (3-Bromopropyl)triphenylphosphonium bromide (279 mg, $0.6 \mathrm{mmol}$ ) were stirred in $5 \mathrm{ml} \mathrm{DMF}$ at $70{ }^{\circ} \mathrm{C}$ for 1 hour. Then the reaction solution was filtered and quenched with saturated $\mathrm{NH}_{4} \mathrm{Cl}$ solution. The solution was extracted by EtOAc and concentrated. The crude product was subjected to column chromatography with $(\mathrm{MeOH}+\mathrm{AcOH})$ in $\operatorname{DCM}(10 \%+2.5 \%)$ as eluents to obtain Me-Mito- ${ }^{13} \mathrm{C}(\mathbf{1 6}, 75 \mathrm{mg}, 0.11 \mathrm{mmol}, 52 \%$ over two steps) as pale white solid.

${ }^{1} \mathrm{H}$ NMR (400 MHz, $\left.\mathrm{CD}_{2} \mathrm{Cl}_{2}\right) \delta 7.90-7.76(\mathrm{~m}, 9 \mathrm{H}), 7.75-7.65(\mathrm{~m}, 6 \mathrm{H}), 6.96(\mathrm{~s}, 2 \mathrm{H}), 6.69$ (s, $2 \mathrm{H}), 4.32(\mathrm{t}, J=5.9 \mathrm{~Hz}, 2 \mathrm{H}), 4.10-3.84(\mathrm{~m}, 2 \mathrm{H}), 2.38-2.22(\mathrm{~m}, 15 \mathrm{H}), 2.22-2.14(\mathrm{~m}, 2 \mathrm{H})$.

${ }^{13} \mathrm{C}$ NMR $\left(100 \mathrm{MHz}, \mathrm{CD}_{2} \mathrm{Cl}_{2}\right) \delta 161.25,151.98,151.76,150.57,150.35,142.76,142.00,139.36$, $135.64,134.33,134.23,131.01,130.88,129.08,119.17,118.31,114.47,67.32,67.15,23.29,21.64$, 21.22, 20.82, 20.36, 19.84 .

HRMS (ESI, m/z): calcd. for $\left[\mathrm{C}_{39}{ }^{13} \mathrm{C}_{2} \mathrm{H}_{40} \mathrm{O}_{2} \mathrm{P}\right]^{+}\left(\mathrm{M}^{+}\right)$, 597.2828; found, 597.2838. 


\section{Stimulated Raman scattering and fluorescence microscopy.}

An integrated laser (picoEMERALD, Applied Physics and Electronics, Inc.) was used as a light source for both pump and Stokes beams. It produces 2 ps pump (tunable from $770 \mathrm{~nm}-990 \mathrm{~nm}$, bandwidth $0.5 \mathrm{~nm}$, spectral bandwidth $\left.\sim 7 \mathrm{~cm}^{-1}\right)$ and Stokes $(1031.2 \mathrm{~nm}$, spectral bandwidth 10 $\mathrm{cm}^{-1}$ ) beams with $80 \mathrm{MHz}$ repetition rate. Stokes beam is modulated at $20 \mathrm{MHz}$ by an internal electro-optic modulator. The spatially and temporally overlapped pump and Stokes beams are introduced into an inverted multiphoton laser scanning microscopy (FV3000, Olympus), and then focused onto the sample by a 25X water objective (XLPLN25XWMP, 1.05 N.A., Olympus). Transmitted pump and Stokes beams are collected by a high N.A. condenser lens (oil immersion, 1.4 N.A., Olympus) and pass through a bandpass filter (893/209 BrightLine, $25 \mathrm{~mm}$, AVR Optics) to filter out Stokes beam. A large area $(10 \times 10 \mathrm{~mm})$ Si photodiode (S3590-09, Hamamatsu) is used to measure the remaining pump beam intensity. $64 \mathrm{~V} \mathrm{DC}$ voltage was used on the photodiode to increase saturation threshold and reduce response time. The output current is terminated by a 50 $\Omega$ terminator and pre-filtered by an 19.2-23.6-MHz band-pass filter (BBP-21.4+, Mini-Circuits) to reduce laser and scanning noise. The signal is then demodulated by a lock-in amplifier (SR844, Stanford Research Systems) at the modulation frequency. The in-phase X output is fed back to the Olympus IO interface box (FV30-ANALOG) of the microscope. Image acquisition speed is limited by $30 \mu$ s time constant set for the lock-in amplifier. Correspondingly, we use $80 \mu$ s pixel dwell time, which gives a speed of $8.5 \mathrm{~s} \mathrm{frame}^{-1}$ for a 320-by-320-pixel field of view. Laser powers are monitored through image acquisition by an internal power meter and power fluctuation are controlled within 5\% by the laser system. 16-bit grey scale images are acquired by Fluoview software. SRS spectra were acquired by fixing the Stokes beam at $1031.2 \mathrm{~nm}$ and scanning the pump beam through the designated wavelength range point by point. $10 \mathrm{mM} \mathrm{EdU}\left(\mathrm{H}_{2} \mathrm{O}\right)$ sample was used as a standard to give RIE of different probes. Fluorescence images were collected using the same Olympus FV3000 confocal microscope with CW laser excitation (405, 488, 561 and 640 $\mathrm{nm}$, Coherent OBIS LX laser) and standard bandpass filter sets. The correlation coefficients (Pearson's R value) between SRS images and fluorescence images were calculated using 'Coloc 2' tool of ImageJ.

\section{Spontaneous Raman spectroscopy.}

Spontaneous Raman spectra were acquired using an upright confocal Raman spectrometer (Horiba Raman microscope; Xplora plus). A $532 \mathrm{~nm}$ YAG laser is used to illuminate the sample with a power of $12 \mathrm{~mW}$ on sample through a $100 \mathrm{x}$, N.A. 0.9 objective (MPLAN N; Olympus) with 100 $\mu \mathrm{m}$ slit and $500 \mu \mathrm{m}$ hole. Spectro/Raman shift center was set to be $2000.04 \mathrm{~cm}^{-1}$. With a 1200 grating, Raman shift ranges from $690.81 \mathrm{~cm}^{-1}$ to $3141.49 \mathrm{~cm}^{-1}$ was acquired to cover whole biological relevant Raman peaks. The acquired spectra were processed by the LabSpec 6 software for baseline correction.

\section{$365 \mathrm{~nm}$ UV irradiation.}

The $365 \mathrm{~nm}$ UV light used to activate cyclopropenones comes from a UV handlamp (Analytik Jena UVP EL Series Lamp, UVLS-24, 4 Watt, 2UV 254/365 nm, typically used for TLC monitoring in organic synthesis). The power of $365 \mathrm{~nm} \mathrm{UV}$ of this handlamp was measured to be $15 \mathrm{~mW} / \mathrm{cm}^{2}$ on samples.

\section{UV-Vis absorption spectra.}

UV-Vis absorption spectra were recorded on a Varian Cary $50 \mathrm{UV}$-Vis Spectrophotometer (Agilent). 
(HP)LC-MS for assessing the stability of cyclopropenone probes in physiological condition. The assessed probe was first dissolved in DMSO and later diluted in $10 \mathrm{mM}$ cysteine (Sigma, 168149, dissolved in PBS) solution or DMEM (Corning, 35-015-CV) medium. Analytical HPLC coupled with mass spectrometry (LC-MS) was performed on Agilent 1290 infinity LC system using ZORBAX RRHD Eclipse Plus C18, 95A, 2.1 x $50 \mathrm{~mm}, 1.8 \mu \mathrm{m}$ column with Agilent 6140 Series Quadrupole LCMS / LC-MS / MSD / Mass Spectrometer System. The mobile phase is water $(0.1 \% \mathrm{AcOH})$ and acetonitrile with running method of gradient $5 \%-95 \%$ acetonitrile $(1 \mathrm{ml} / \mathrm{min}$, $4 \mathrm{~min}$ for total running time). The mass spectrometry detection region ranges from 100 to 800 AMU. The data shown in the main figures and supplementary figures are the absorption (280.8 nm) intensity traces.

\section{Cell culture.}

HeLa cells (ATCC) were cultured in DMEM (Corning, 10-013-CV), supplemented with 10\% fetal bovine serum (Corning, 35-015-CV), and 1\% penicillin-streptomycin (Sigma-Aldrich). Cultures were incubated in a water-saturated incubator at $37^{\circ} \mathrm{C}$ with $5 \% \mathrm{CO}_{2}$. Cells were passaged every 35 days once confluence reached $80 \%$. Cultured HeLa cells were seeded onto $14 \mathrm{~mm}$ glass-bottom microwell dishes (MatTek Corporation) and grew to 80-90 \% confluence before labeling.

\section{Live/dead cell viability assay.}

This assay was performed using the LIVE/DEAD viability/cytotoxicity kit for mammalian cells (Molecular Probes L-3224). HeLa cell standards and HeLa cells with dye staining were incubated with $2 \mu \mathrm{M}$ calcein $\mathrm{AM}$ and $4 \mu \mathrm{M}$ ethidium homodimer-1 (EthD-1) working solution for 20 min at $37^{\circ} \mathrm{C}$ before imaging.

\section{Live-cell photo-uncaging organelle imaging. Mitochondria imaging:}

Cells were incubated in $16 \mu \mathrm{M}$ Me-Mito (12) or Me-Mito- ${ }^{13} \mathrm{C}(\mathbf{1 6})$ with complete DMEM medium for 40 minutes in the incubator. Cells were washed with PBS three times before imaging. For colocalization, $80 \mathrm{nM}$ MitoTracker ${ }^{\mathrm{TM}}$ Deep Red (Invitrogen, M22426) was used to stain cells for 25 minutes. For photo-uncaging, $405 \mathrm{~nm}$ laser (OBIS LX $405 \mathrm{~nm} 50 \mathrm{~mW}$ Laser, the same $405 \mathrm{~nm}$ laser used below) was used to scan the selected field of view for 2 minutes (1.6 $\mathrm{mW}$ on samples).

\section{Lysosomes imaging.}

Cells were incubated in $30 \mu \mathrm{M}$ Me-Lyso (13) with complete DMEM medium for 2 hours in the incubator. Cells were washed with PBS three times before imaging. For colocalization, $0.4 \mathrm{x}$ LysoView ${ }^{\mathrm{TM}} 488$ (Biotium, \#70067) was used to stain cells for 30 minutes. For photo-uncaging, $405 \mathrm{~nm}$ laser was used to scan the selected field of view for 2 minutes $(1.6 \mathrm{~mW})$.

\section{ER imaging.}

Cells were incubated in $40 \mu \mathrm{M}$ Me-ER (14) with complete DMEM medium for 2 hours in the incubator. Cells were washed with PBS three times before imaging. For colocalization, $0.5 \mu \mathrm{M}$ ER-Tracker ${ }^{\mathrm{TM}}$ Red (Invitrogen, E34250) was used to stain cells for 1 hour. For photo-uncaging, $405 \mathrm{~nm}$ laser was used to scan the selected field of view for 2 minutes $(1.6 \mathrm{~mW})$. 


\section{Lipid droplets imaging by Me-LD (15).}

Cells were incubated in $20 \mu \mathrm{M}$ Me-LD (15) with complete DMEM medium for 30 minutes in the incubator. Cells were washed with PBS three times before imaging. For colocalization, $0.5 \mathrm{x}$ LipidSpot $^{\mathrm{TM}} 610$ (Biotium, \#70069) was used to stain cells for 20 minutes. For photo-uncaging, $405 \mathrm{~nm}$ laser was used to scan the selected field of view for 2 minutes $(1.6 \mathrm{~mW})$.

\section{Lipid droplets imaging by Cyclo-LD (17).}

Cells were washed with PBS for three times before labeling. Cells were then incubated in $20 \mu \mathrm{M}$ Cyclo-LD (17) with PBS for 30 minutes in the incubator. Cells were washed with PBS three times before imaging. For colocalization, $0.5 \mathrm{x} \mathrm{LipidSpot}^{\mathrm{TM}} 610$ (Biotium, \#70069) was used to stain cells for 20 minutes. For photo-uncaging, $405 \mathrm{~nm}$ laser $(1.6 \mathrm{~mW})$ was used to scan the selected field of view for 2 minutes.

Two-color tracking with Me-LD (15) and Me-Mito- ${ }^{13} \mathrm{C}(16)$. Cells were incubated in $10 \mu \mathrm{M}$ Me-LD (15) and $20 \mu \mathrm{M}$ Me-Mito- ${ }^{13} \mathrm{C}(\mathbf{1 6})$ with complete DMEM medium for 30 minutes in the incubator. Cells were washed with PBS three times before imaging. For selective uncaging, $405 \mathrm{~nm}$ laser was used to scan the selected field of view for 15 seconds $(0.8 \mathrm{~mW})$.

Three-color targeted photo-uncaging imaging with Cyclo-LD (17), Me-Lyso (13) and MeMito- ${ }^{13} \mathrm{C}$ (16).

Cells were incubated in $40 \mu \mathrm{M}$ Me-Lyso (13) with complete DMEM medium for 4 hours and 20 $\mu \mathrm{M}$ Me-Mito- ${ }^{13} \mathrm{C}(\mathbf{1 6})$ with complete DMEM medium for 30 minutes in the incubator. Cells were washed with PBS three times. Cells were then incubated in $15 \mu \mathrm{M}$ Cyclo-LD (17) with PBS for 15 minutes at room temperature. Cells were washed with PBS three times before imaging. For photo-uncaging, $405 \mathrm{~nm}$ laser was used to scan the selected field of view for 2 minutes $(1.6 \mathrm{~mW})$.

\section{Quantification of SRS laser uncaging.}

Cells were incubated in $20 \mu \mathrm{M}$ Me-Mito (12) with complete DMEM medium for 30 minutes in the incubator. Cells were washed with PBS three times before imaging. After taking one image at $\mathrm{CH}_{3}$ channel $\left(2940 \mathrm{~cm}^{-1}\right)$ at low powers $(10 \mathrm{~mW}$ OPO and $10 \mathrm{~mW}$ Stokes, $80 \mu \mathrm{s} /$ pixel $), 10$ frames of images at $2205 \mathrm{~cm}^{-1}$ were taken at various OPO and Stokes powers sequentially, followed by $405 \mathrm{~nm}$ illumination. The image acquired after $405 \mathrm{~nm}$ irradiation was assigned as 100\% signal frame. The signal of each frame in the 10 images set was divided by the signal of $405 \mathrm{~nm}$ irradiated frame (100\% signal frame) to obtain its percentage. Our criterion for the powers used were to let the intensity gain of each frame be less than $1.5 \%$, so we chose $25 \mathrm{~mW}$ OPO and $60 \mathrm{~mW}$ Stokes for imaging. 

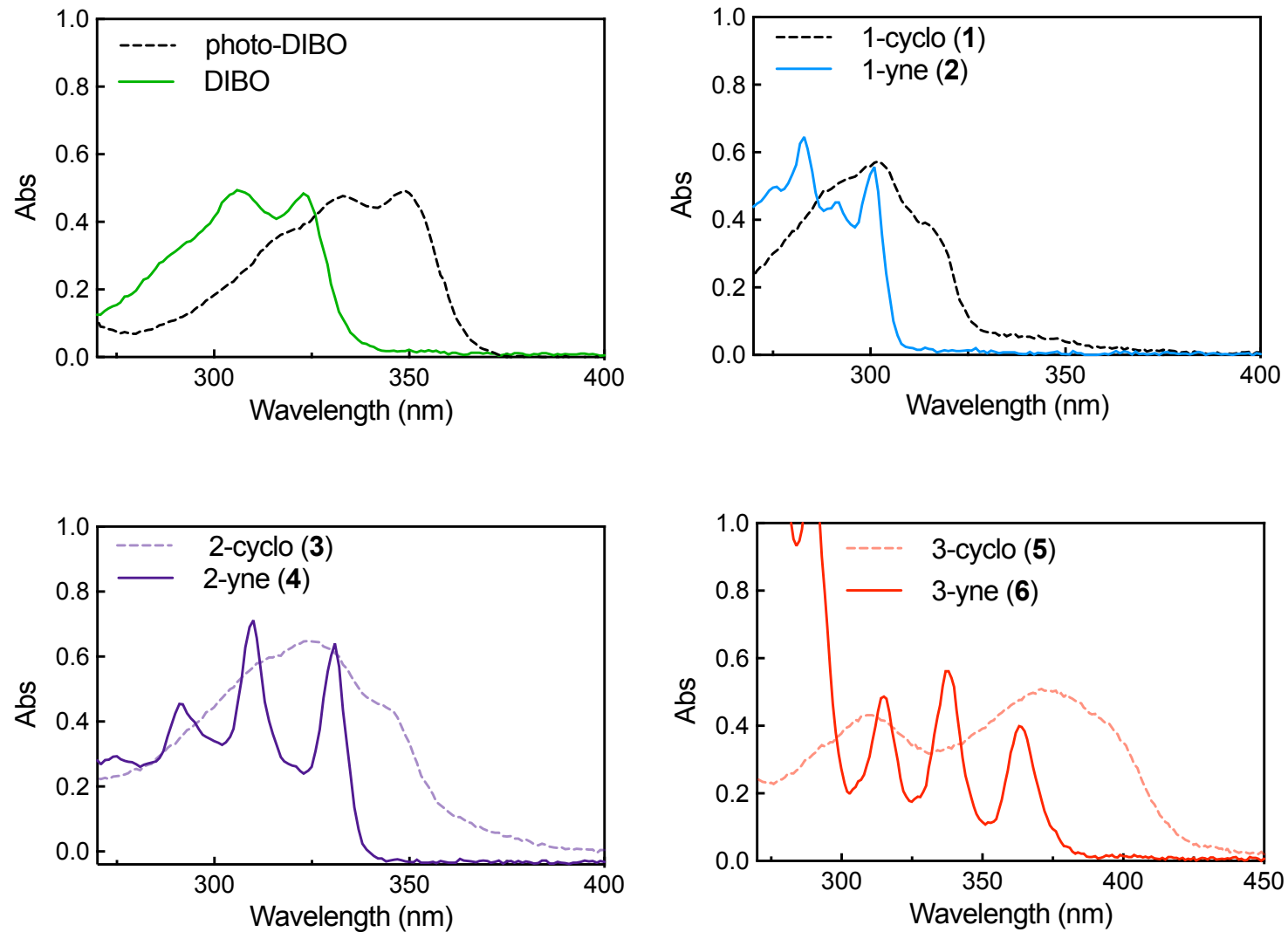

Figure S1. UV-Vis absorption spectra of $20 \mu \mathrm{M}$ photo-DIBO, 1-cyclo (1), 2-cyclo (3) and 3cyclo (5) and their corresponding alkyne products, shown in Fig. 1A, in DMSO. 
$\mathrm{CH}_{3}$

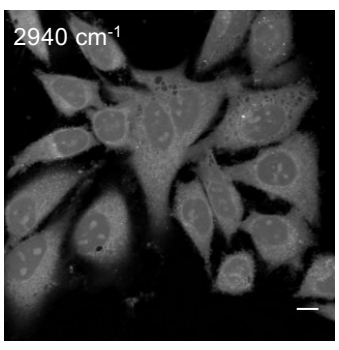

$\mathrm{CH}_{3}$

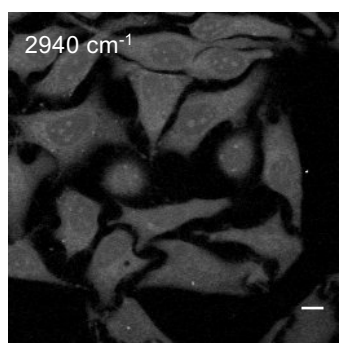

Before 405

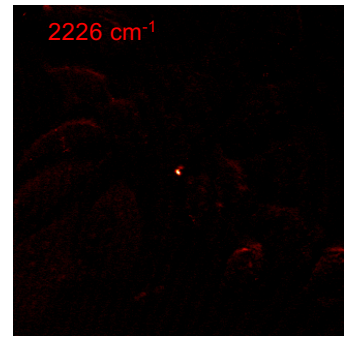

Before 405

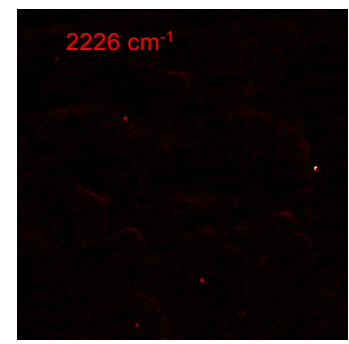

After 405
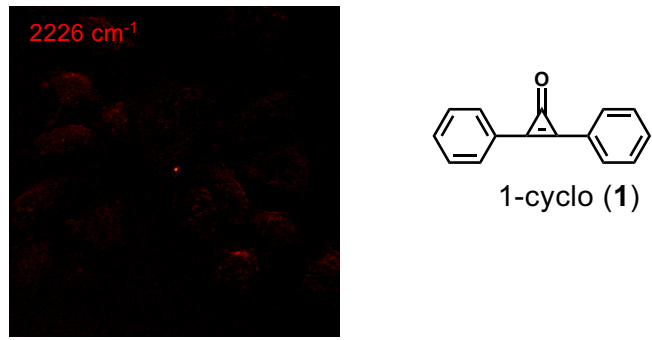

1-cyclo (1)

After 405

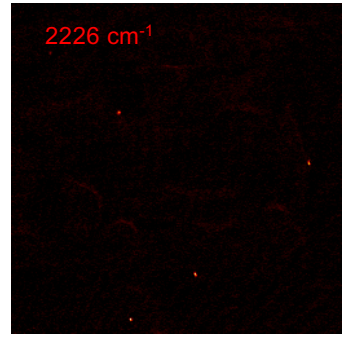

Figure S2. SRS imaging of live HeLa cells incubated with 1-cyclo (1, $20 \mu \mathrm{M}, 30$ minutes of labeling, top) and Cyclo-Mito (7, $20 \mu \mathrm{M}, 30$ minutes of labeling, bottom) at the $\mathrm{CH}_{3}\left(2940 \mathrm{~cm}^{-1}\right)$ channel, and the expected uncaged alkyne channel $\left(2226 \mathrm{~cm}^{-1}\right)$ before and after $405 \mathrm{~nm}$ illumination. Scale bar: $10 \mu \mathrm{m}$.

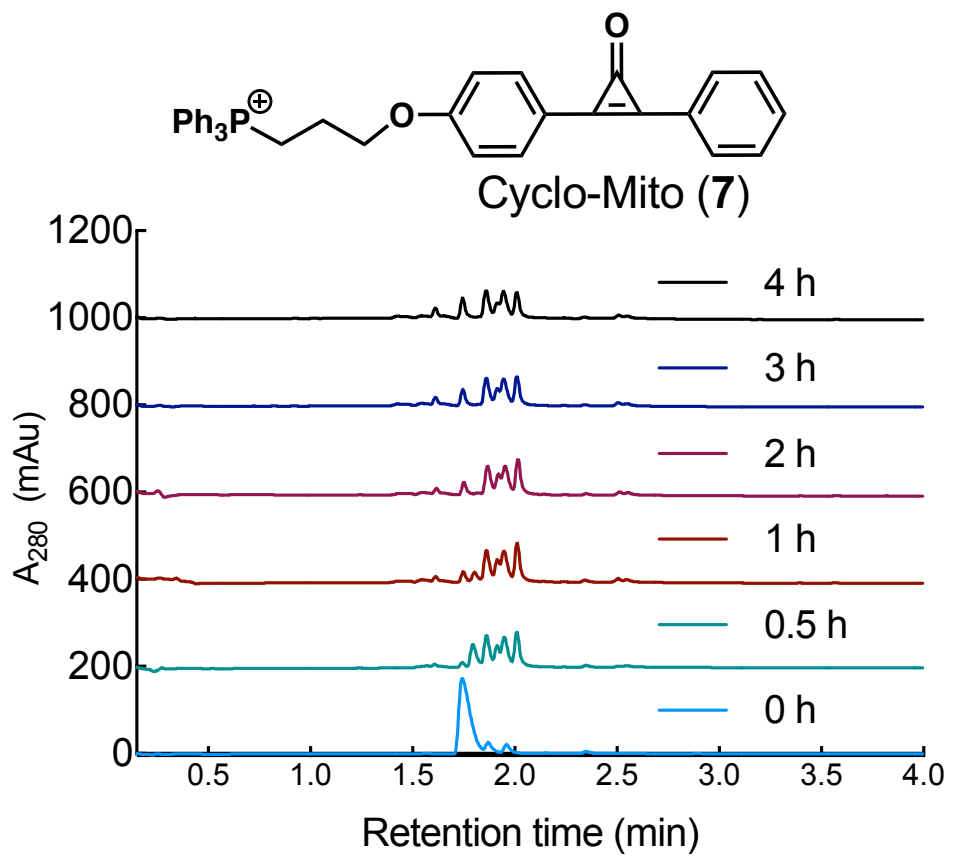

Figure S3. HPLC trace of Cyclo-Mito (7) after incubating in $10 \mathrm{mM}$ cysteine (PBS) for designated duration at $37^{\circ} \mathrm{C}$. 


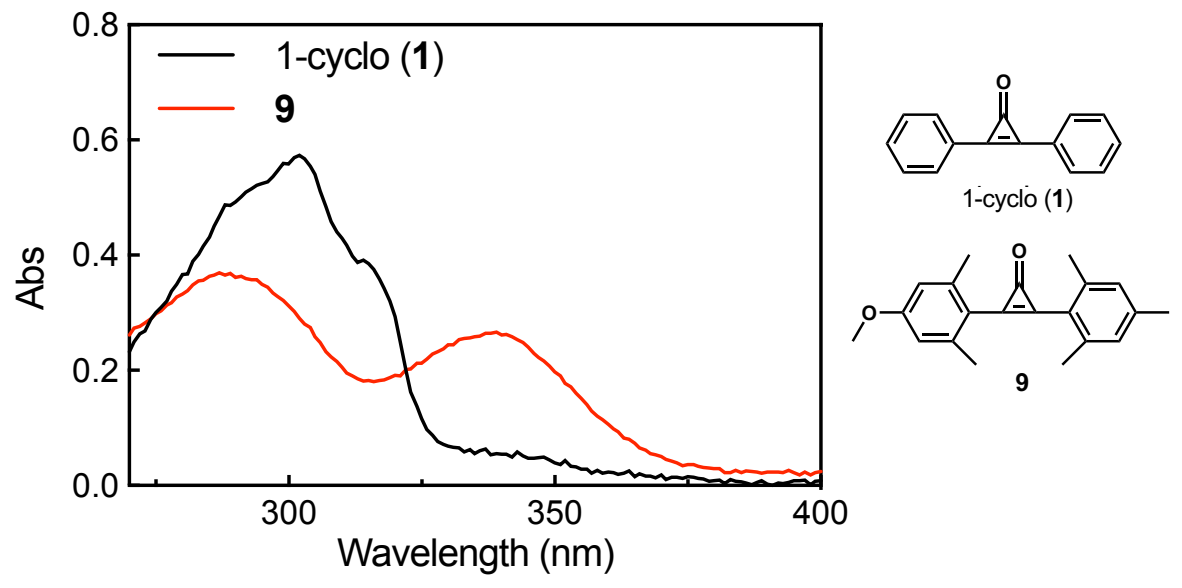

Figure S4. UV-Vis absorption spectra of $20 \mathrm{uM} \mathrm{1-cyclo} \mathrm{(1,} \mathrm{black)} \mathrm{and} 9$ (red) in DMSO.

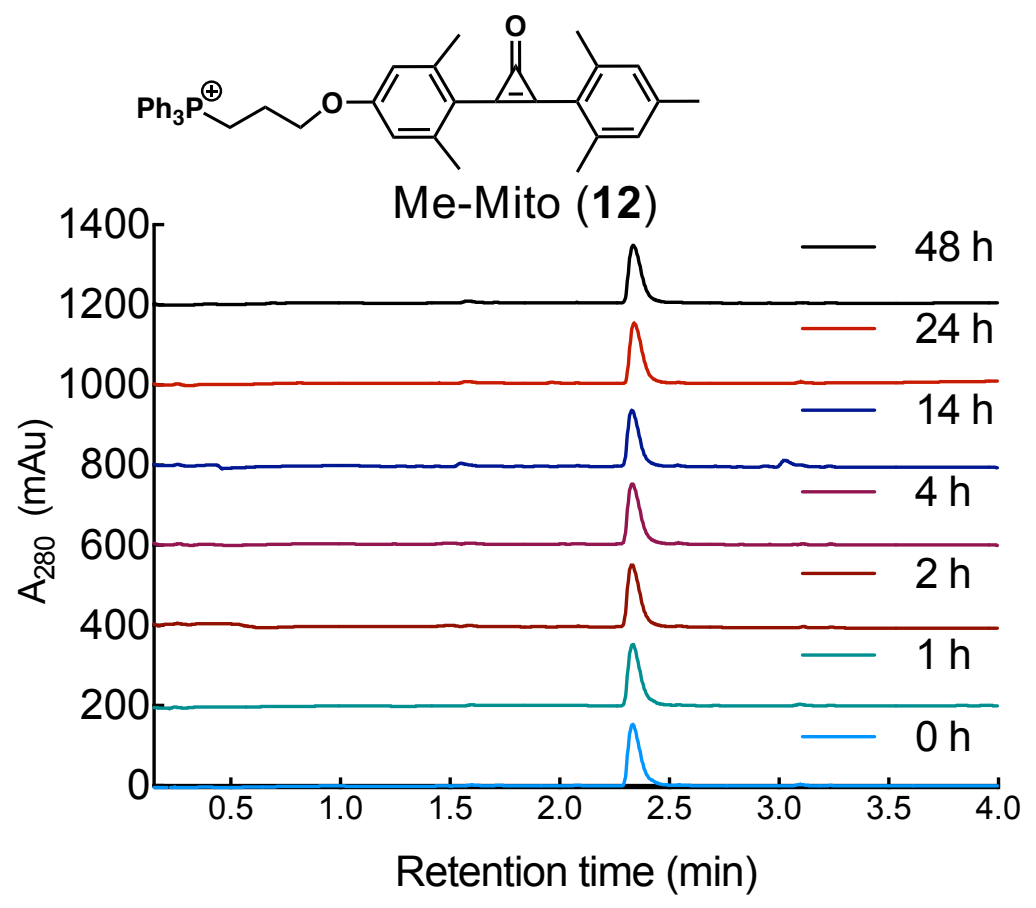

Figure S5. HPLC trace of Me-Mito (12) after incubating in $10 \mathrm{mM}$ cysteine (PBS) for designated duration at $37^{\circ} \mathrm{C}$. 


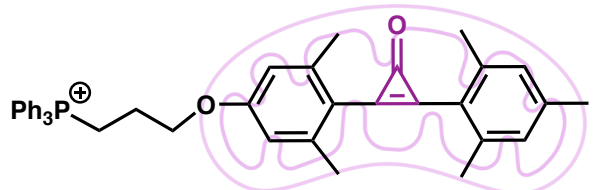

Me-Mito (12)
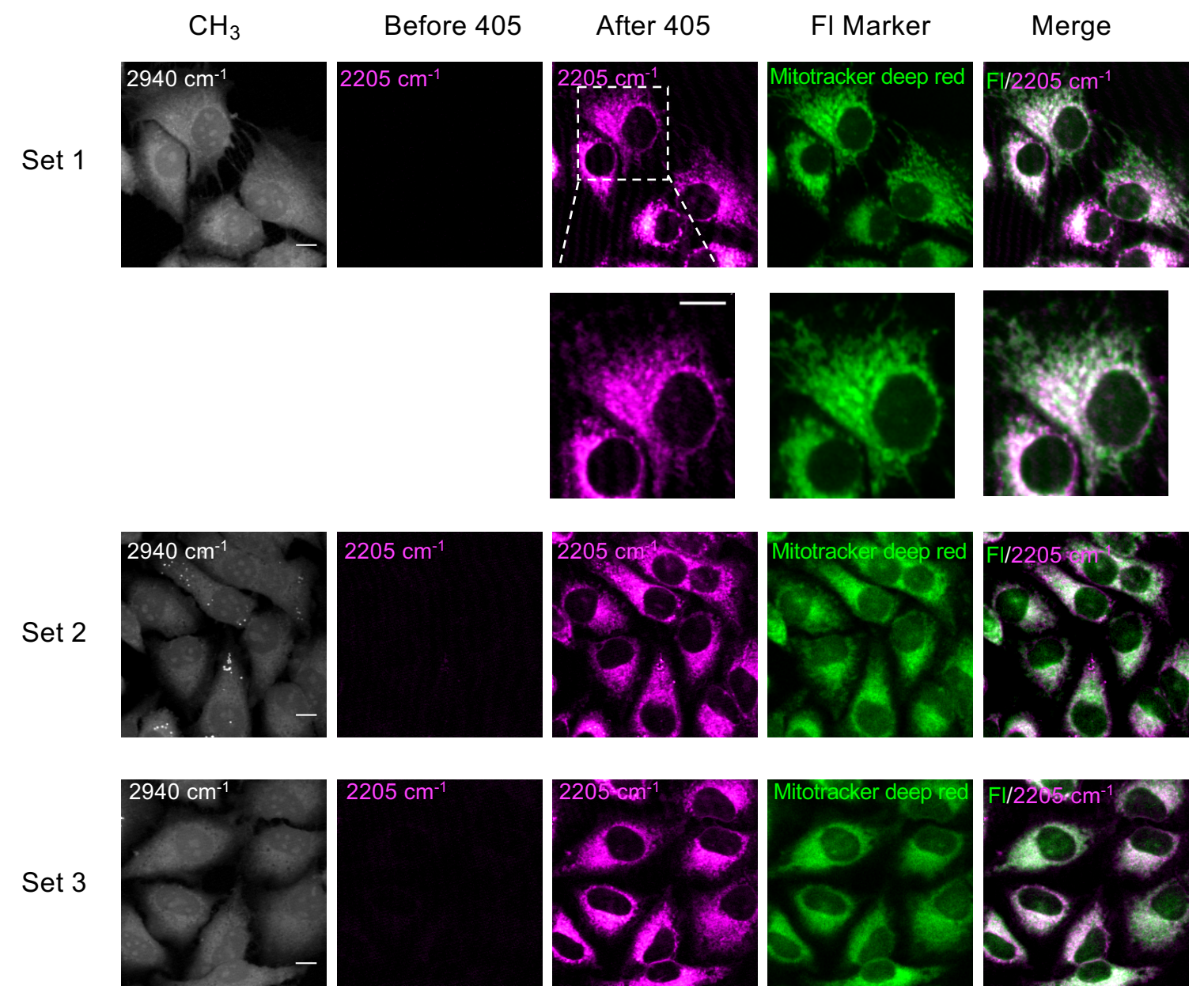

Figure S6. The magnified images of Figure 3a (set 1) and two independent sets of correlative SRS imaging of Me-Mito (12) and fluorescence imaging of Mitotracker deep red in live HeLa cells. The correlation coefficients (Pearson's R value) for set 1 , set 2 and set $3\left(\mathrm{Fl} / 2225 \mathrm{~cm}^{-1}\right.$ channel) are $0.85,0.82$ and 0.88 respectively. Scale bar: $10 \mu \mathrm{m}$. 

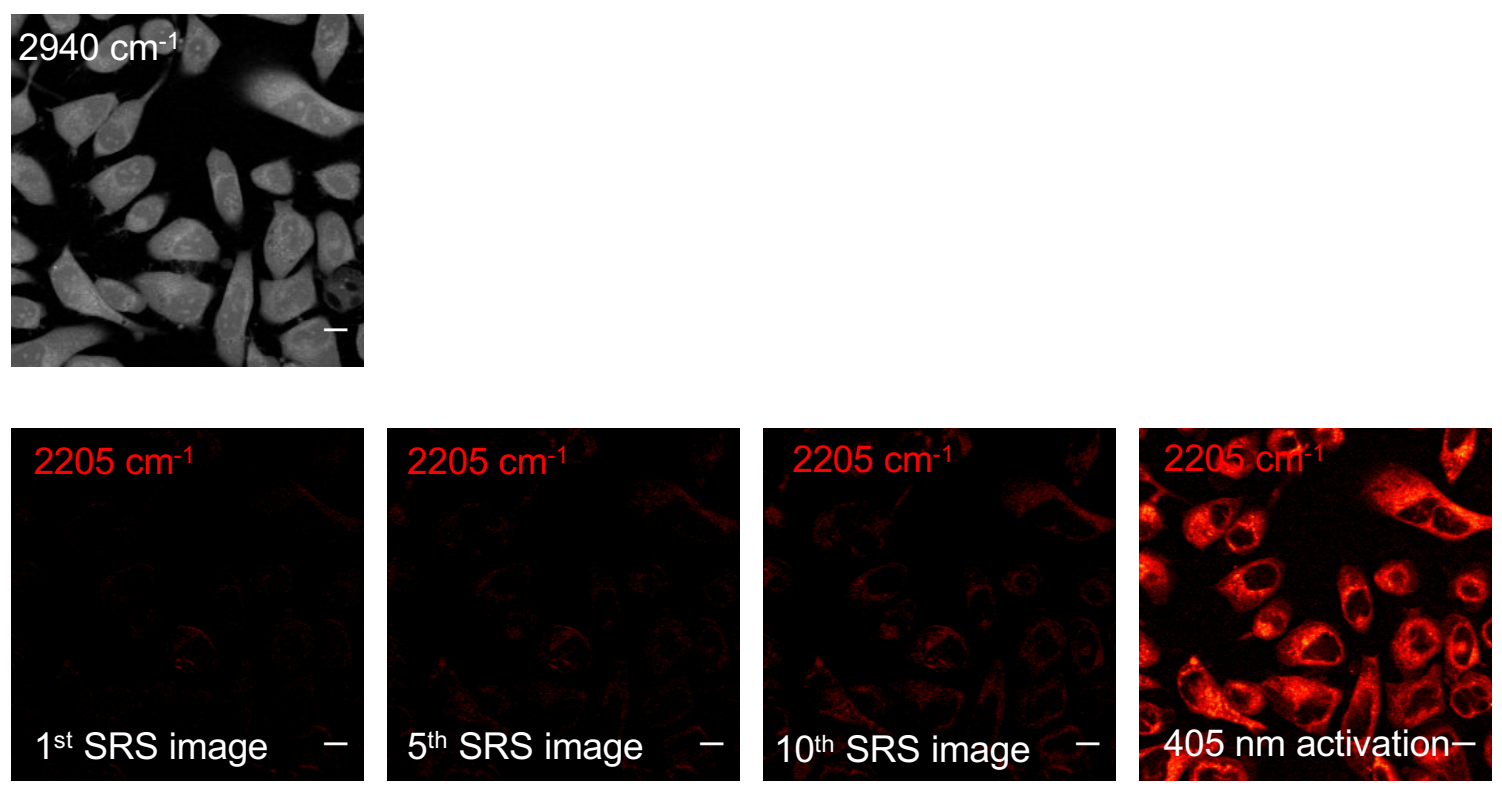

\section{Frame}

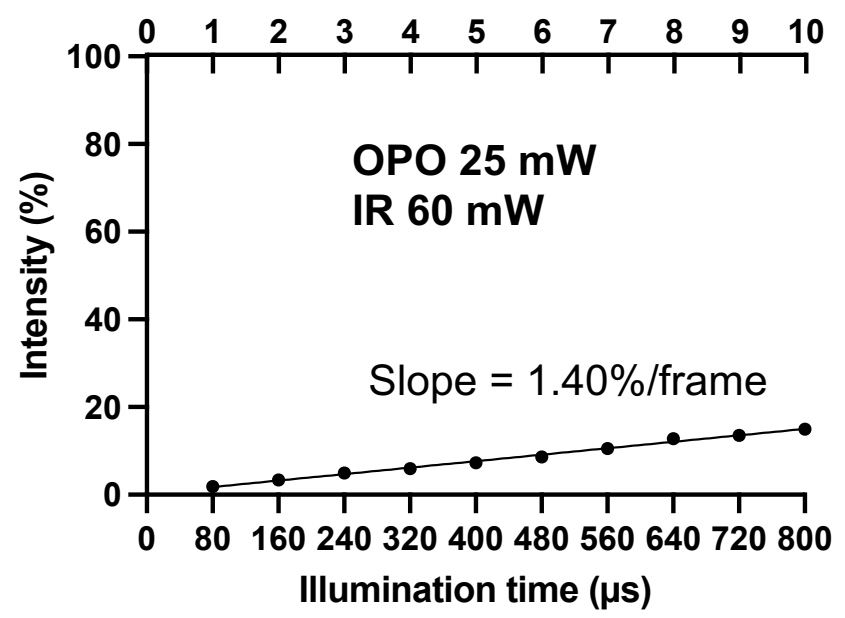

Figure S7. Characterizations of Me-Mito (12) photoactivation by SRS imaging lasers. 10 consecutive frames of SRS images $\left(2205 \mathrm{~cm}^{-1}\right.$, The representative $1^{\text {st }}, 5^{\text {th }}, 10^{\text {th }}$ images are shown) taken on live HeLa cells $\left(\mathrm{CH}_{3}\right.$ SRS imaging at $2940 \mathrm{~cm}^{-1}$ outlines the cell morphology) after incubation with $20 \mu \mathrm{M}$ Me-Mito (12) for 30 minutes. SRS imaging at $2205 \mathrm{~cm}^{-1}$ after full photoactivation (405 $\mathrm{nm}$ activation) is also shown for 100\% intensity benchmark for Me-Mito (12) labeling. The relative SRS activated intensity over SRS laser illumination time is plotted in the bottom (the SRS intensity after $405 \mathrm{~nm}$ activation is set as 100\%). Average frame activation is $1.4 \%$ at the chosen condition: OPO and Stokes powers are $25 \mathrm{~mW}$ and $60 \mathrm{~mW}$, respectively; and pixel dwell time is $80 \mu \mathrm{s} /$ pixel for each image frame. Scale bar: $10 \mu \mathrm{m}$. 


\begin{tabular}{|c|c|c|}
\hline OPO $(\mathrm{mW})$ & Stokes $(\mathrm{mW})$ & Intensity gain $(\%) /$ Frame $(80 \mu \mathrm{s} /$ pixel $)$ \\
\hline 38 & 40 & 2.1 \\
\hline 25 & 60 & 1.4 \\
\hline 20 & 75 & 2.3 \\
\hline 13 & 120 & 2.3 \\
\hline 6 & 225 & 5.3 \\
\hline 13 & 75 & 1.0 \\
\hline 13 & 150 & 2.6 \\
\hline 25 & 105 & 4.9 \\
\hline
\end{tabular}

Table S1. Intensity gain per frame under different power combinations of the OPO and Stokes lasers with a pixel dwell time of $80 \mu \mathrm{s} /$ pixel. Red-colored conditions indicate the selection of our SRS imaging conditions with an average per frame activation less than $1.5 \%$. 
a

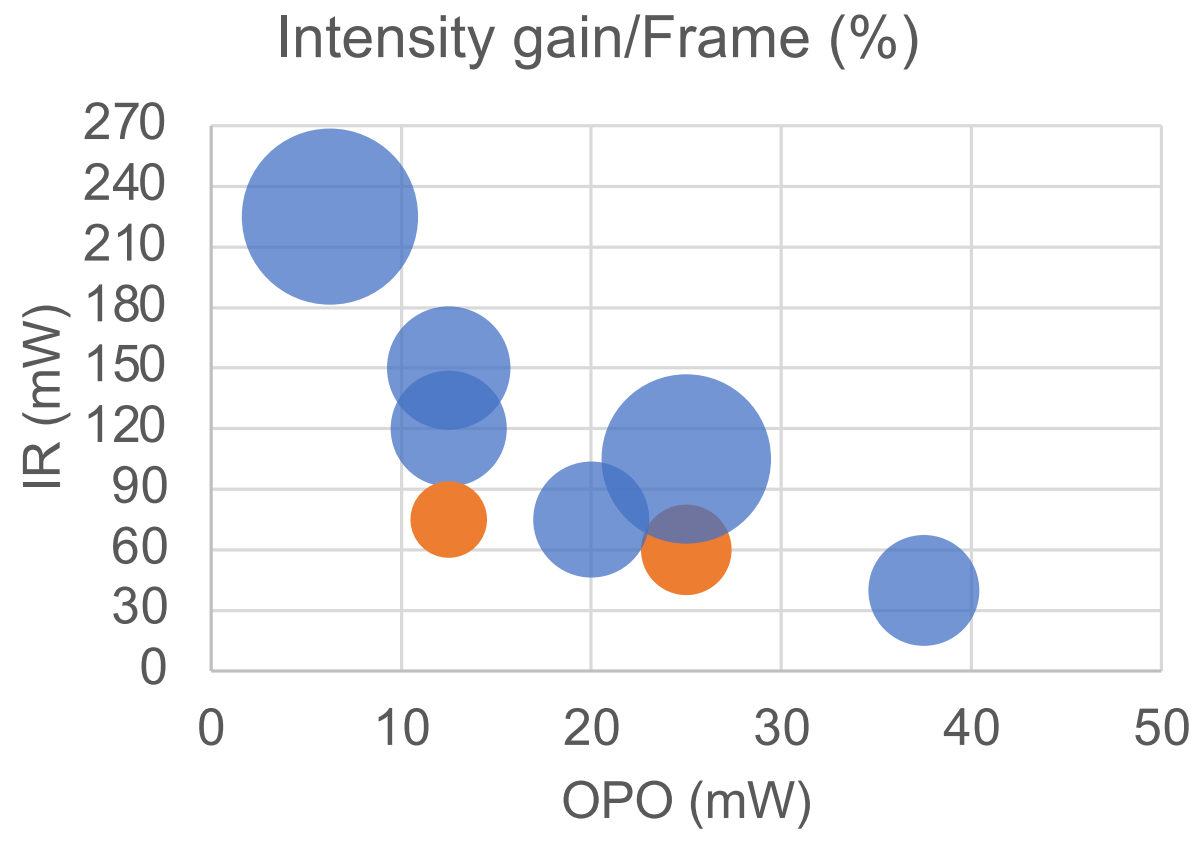

b

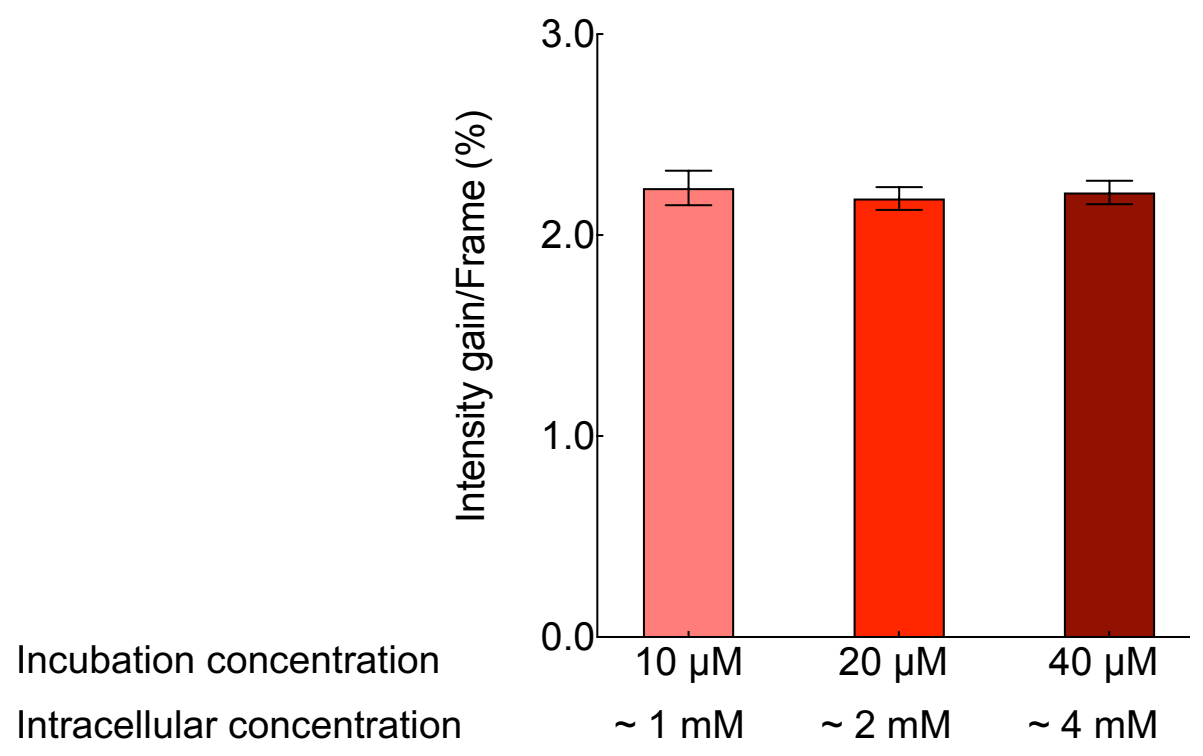

Figure S8. (a)The plot for intensity gain per frame at different power conditions shown in Table S1. The size of the cycles is proportional to the intensity gain per frame. (b) SRS Intensity gain per imaging frame (Intensity gain/frame) from time-series SRS imaging is plotted on live HeLa cells incubated with the indicated concentration of Me-Mito (12) probe for 30 minutes. The intracellular labeling concentration is calculated by the signal level after final $405 \mathrm{~nm}$ activation and benchmarked with the SRS standard curve from the uncaged probe solutions. SRS laser powers: $40 \mathrm{~mW}$ for OPO and $40 \mathrm{~mW}$ for Stokes, respectively. $\mathrm{n}=4$ independent experiments. Data shown as mean \pm SEM. 


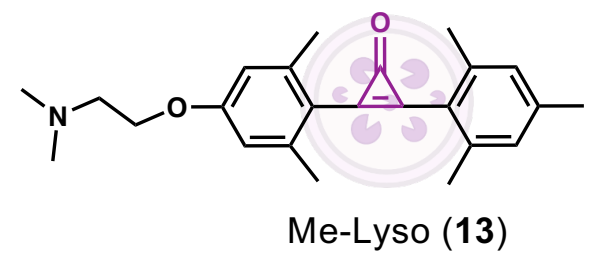

$\mathrm{CH}_{3} \quad$ Before $405 \quad$ After $405 \quad$ FI Marker $\quad$ Merge

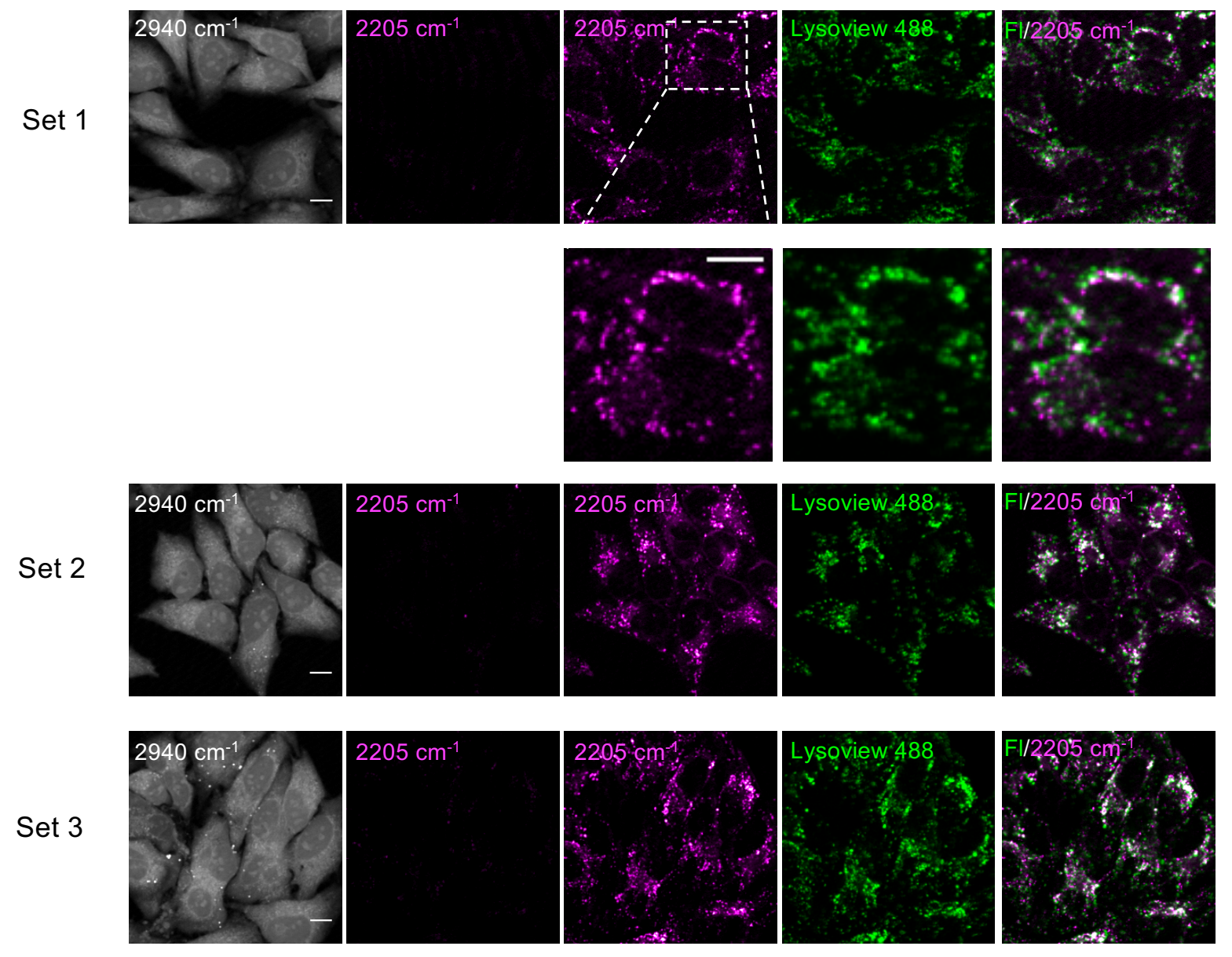

Figure S9. The magnified images of Figure $3 b$ (set 1) and two independent sets of correlative SRS imaging of Me-Lyso (13) and fluorescence imaging of Lysoview 488 in live HeLa cells. The correlation coefficients (Pearson's R value) for set 1, set 2 and set $3\left(\mathrm{Fl} / 2205 \mathrm{~cm}^{-1}\right.$ channel) are $0.60,0.67$ and 0.62 respectively. We note that, the lowered Pearson's $\mathrm{R}$ are mainly due to the active movements of lysosomes in the live cells, from the 3-5 min gap (2 minutes of $405 \mathrm{~nm}$ laser illumination + SRS laser tuning time) between acquiring fluorescence and photoactivated SRS images. Scale bar: $10 \mu \mathrm{m}$. 

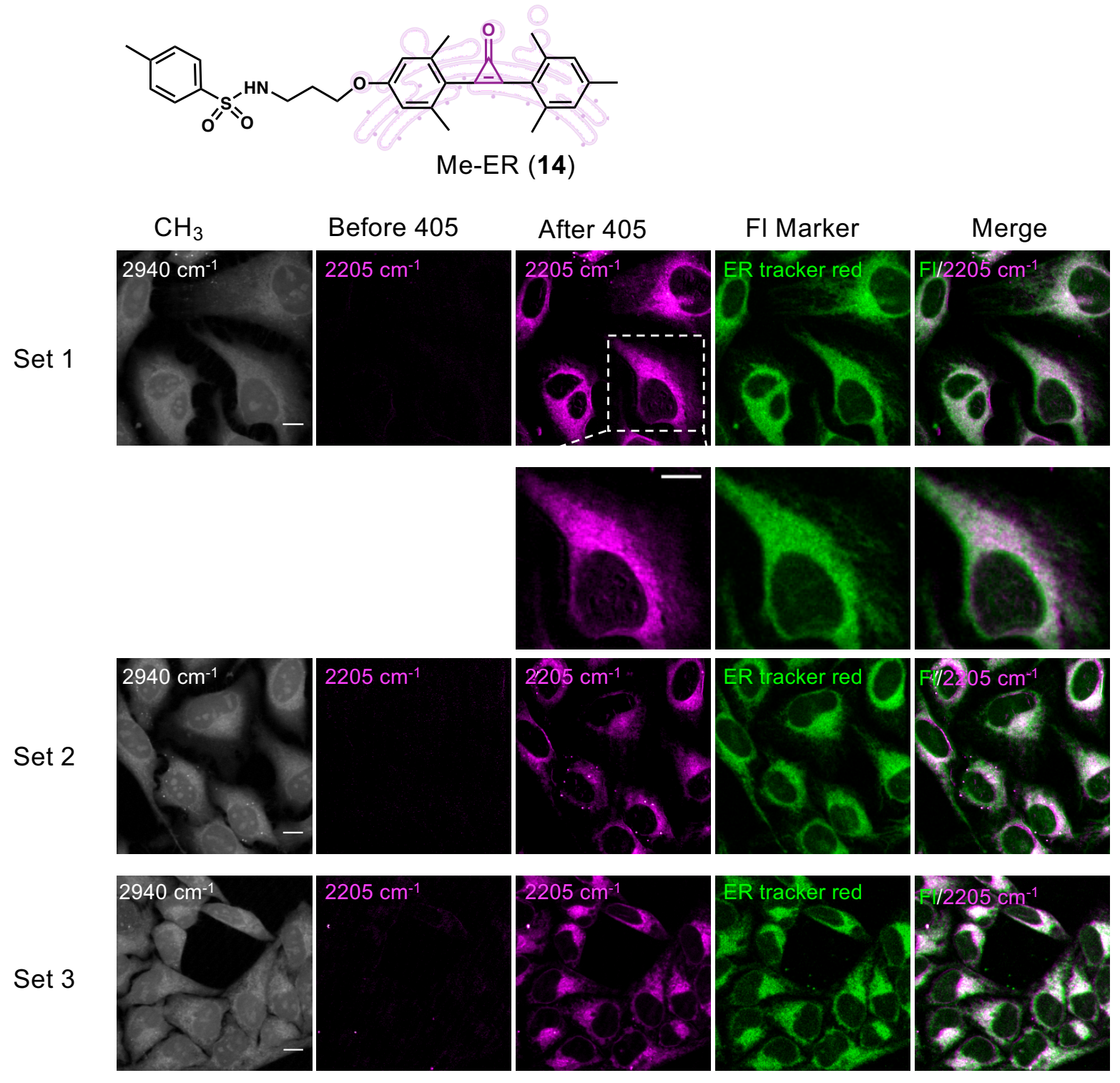

Figure S10. The magnified images of Figure 3c (set 1) and two independent sets of correlative SRS imaging of Me-ER (14) and fluorescence imaging of ER tracker red in live HeLa cells. The correlation coefficients (Pearson's R value) for set 1, set 2 and set $3\left(\mathrm{Fl} / 2205 \mathrm{~cm}^{-1}\right.$ channel) are $0.86,0.80$ and 0.90 respectively. Scale bar: $10 \mu \mathrm{m}$. 

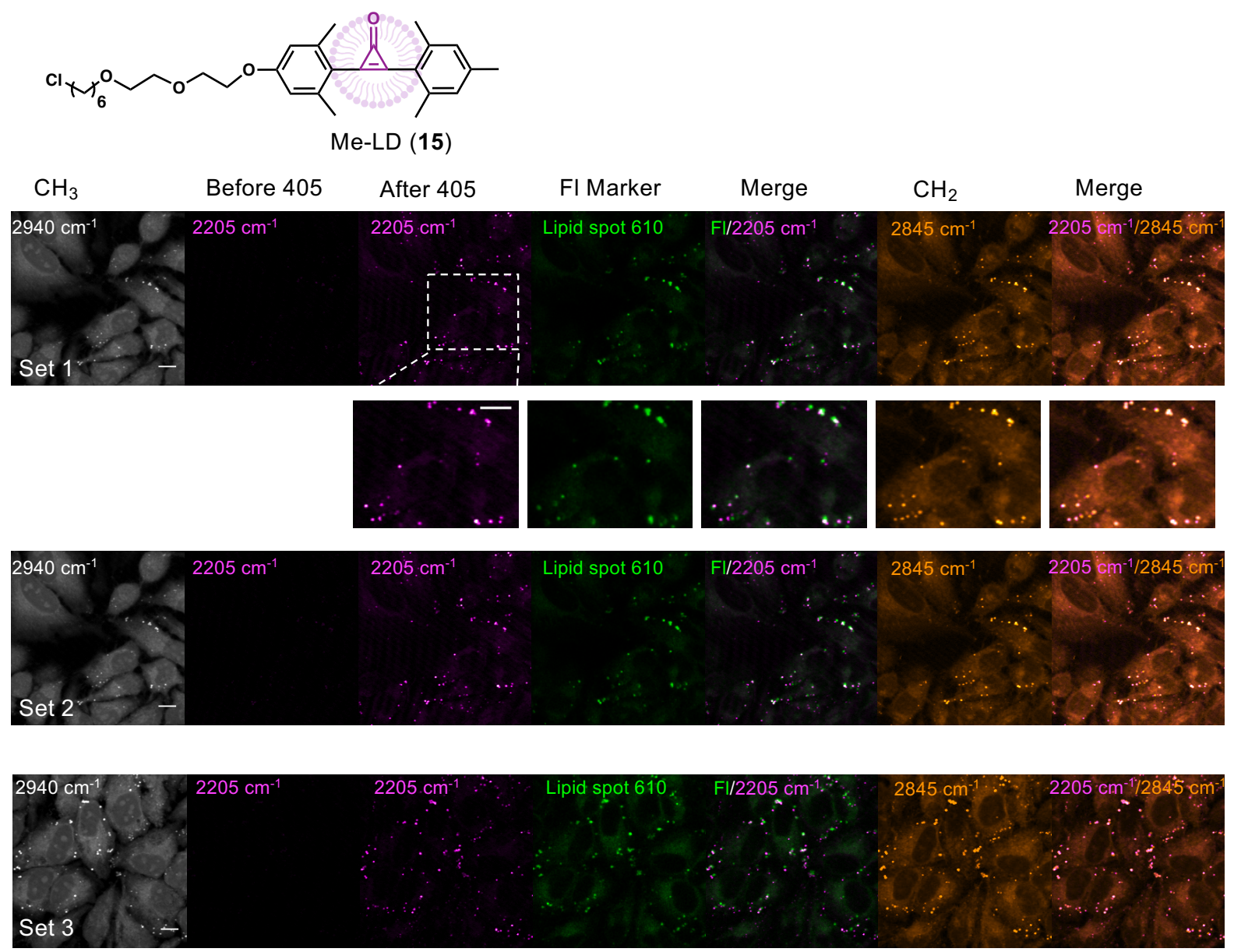

Figure S11. The magnified images of Figure 3d (set 1) and two independent sets of correlative SRS imaging of Me-LD (15) and fluorescence imaging of Lipid spot 610 in live HeLa cells. The correlation coefficients (Pearson's R value) for set 1 , set 2 and set $3\left(\mathrm{Fl} / 2205 \mathrm{~cm}^{-1}\right.$ channel) are $0.54,0.54$ and 0.50 respectively. We note that, the lowered Pearson's $\mathrm{R}$ are mainly due to the active movements of lipid droplets in the live cells, from the 3-5 min gap (2 minutes of $405 \mathrm{~nm}$ laser illumination + SRS laser tuning time) between acquiring fluorescence and photoactivated SRS images. The colocalization is much improved between the $2205 \mathrm{~cm}^{-1}$ channel and the labelfree $\mathrm{CH}_{2}$ lipid channel $\left(2845 \mathrm{~cm}^{-1}\right)$, which are acquired within 1-min time interval. Scale bar: 10 $\mu \mathrm{m}$. 

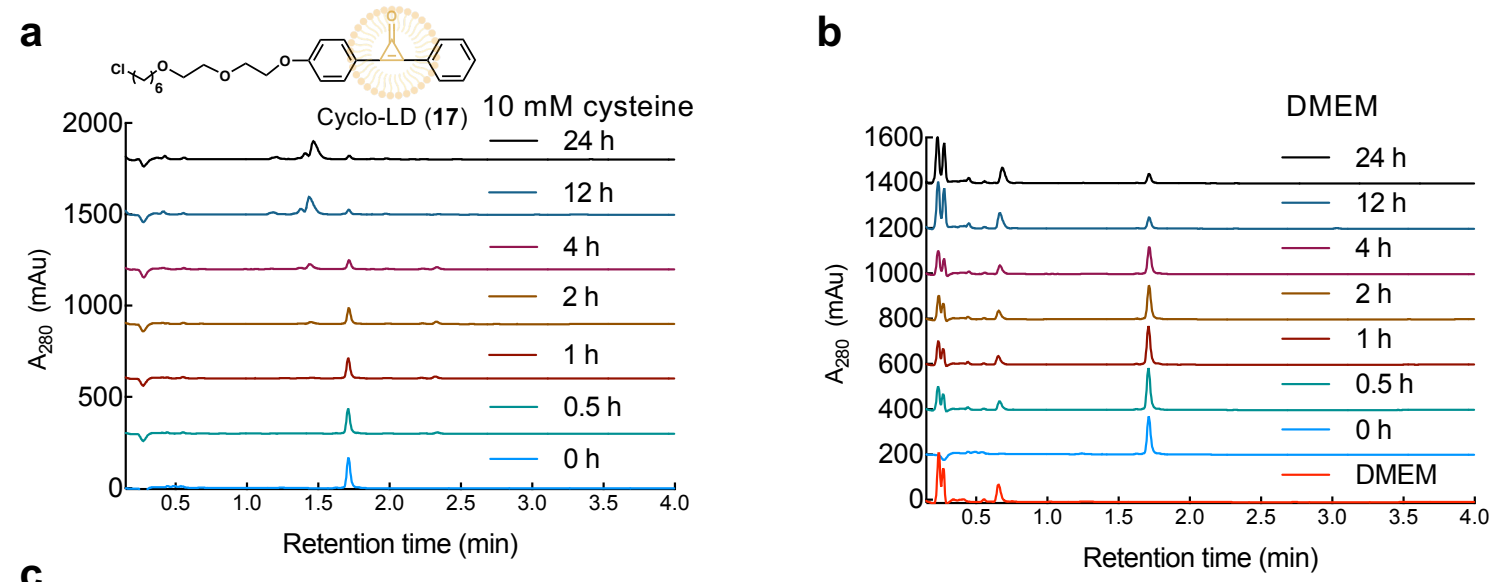

C
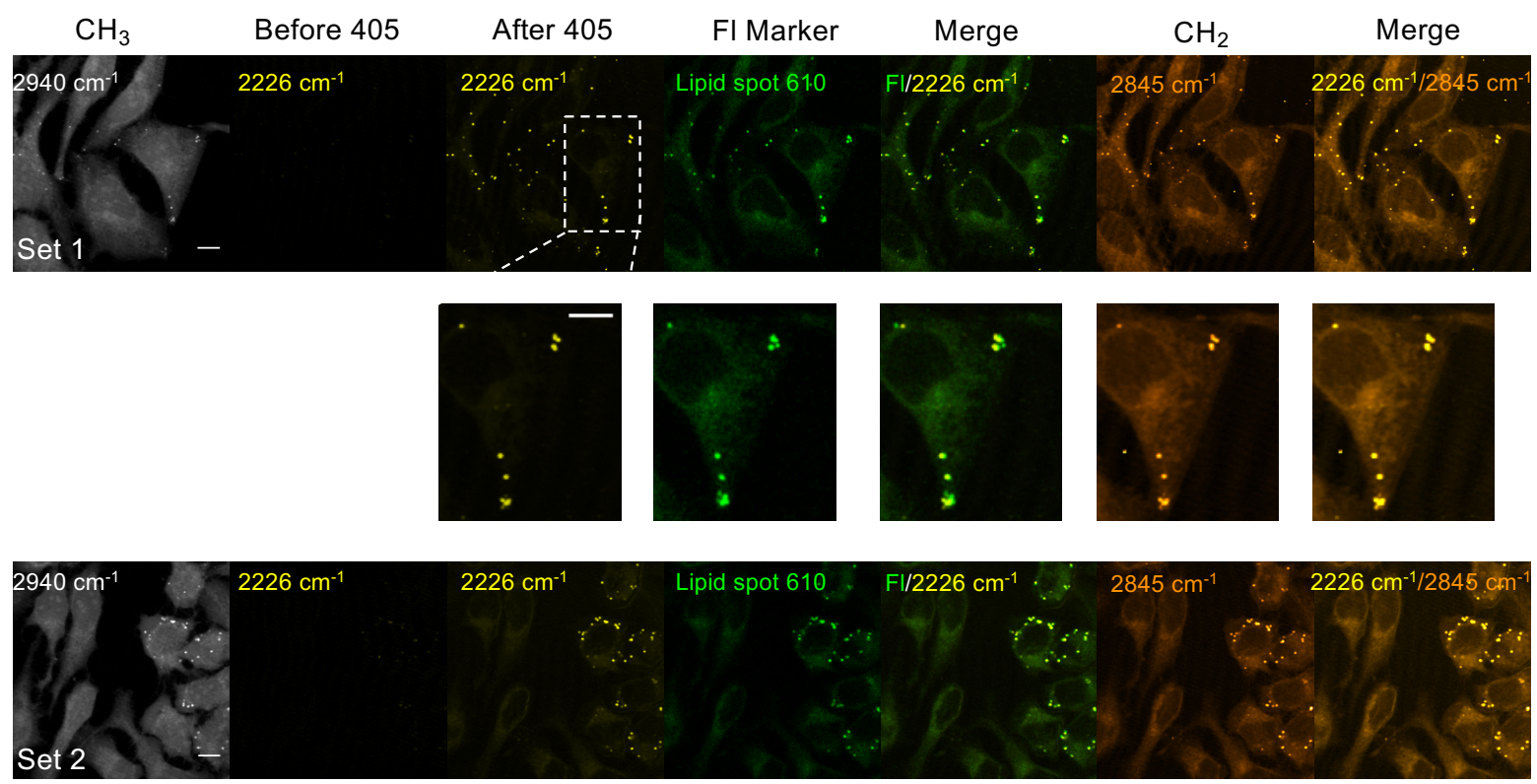

Figure S12. (a-b) The stability of Cyclo-LD (17) in $10 \mathrm{mM}$ cysteine in PBS (a), and DMEM (b) at $37^{\circ} \mathrm{C}$. (c) Two independent sets of correlative SRS imaging of Cyclo-LD (17) and fluorescence imaging of Lipid spot 610 in live HeLa cells. The correlation coefficients (Pearson's R value) for set 1 and set $2\left(\mathrm{Fl} / 2226 \mathrm{~cm}^{-1}\right.$ channel) are 0.50 and 0.76 respectively, which is again lowered due to active droplet movements. Scale bar: $10 \mu \mathrm{m}$. 

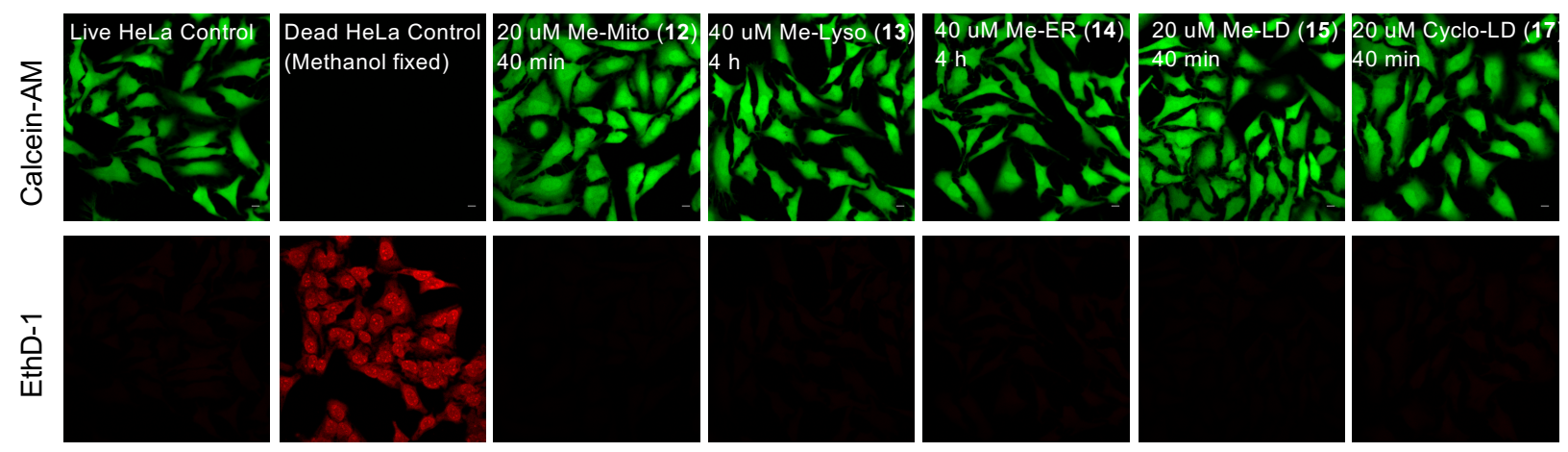

Figure S13. Minimum chemical toxicity of cyclopropenone dyes. Control fluorescence images for live/dead cell-viability assay for live HeLa cells (calcein-AM, green, as live cell indicator) and fixed cells (EthD-1, red, as dead cell indicator). The live HeLa cells were labeled with the indicated probe for the indicated time before performing live/dead cell-viability assay. Scale bar: $10 \mu \mathrm{m}$.
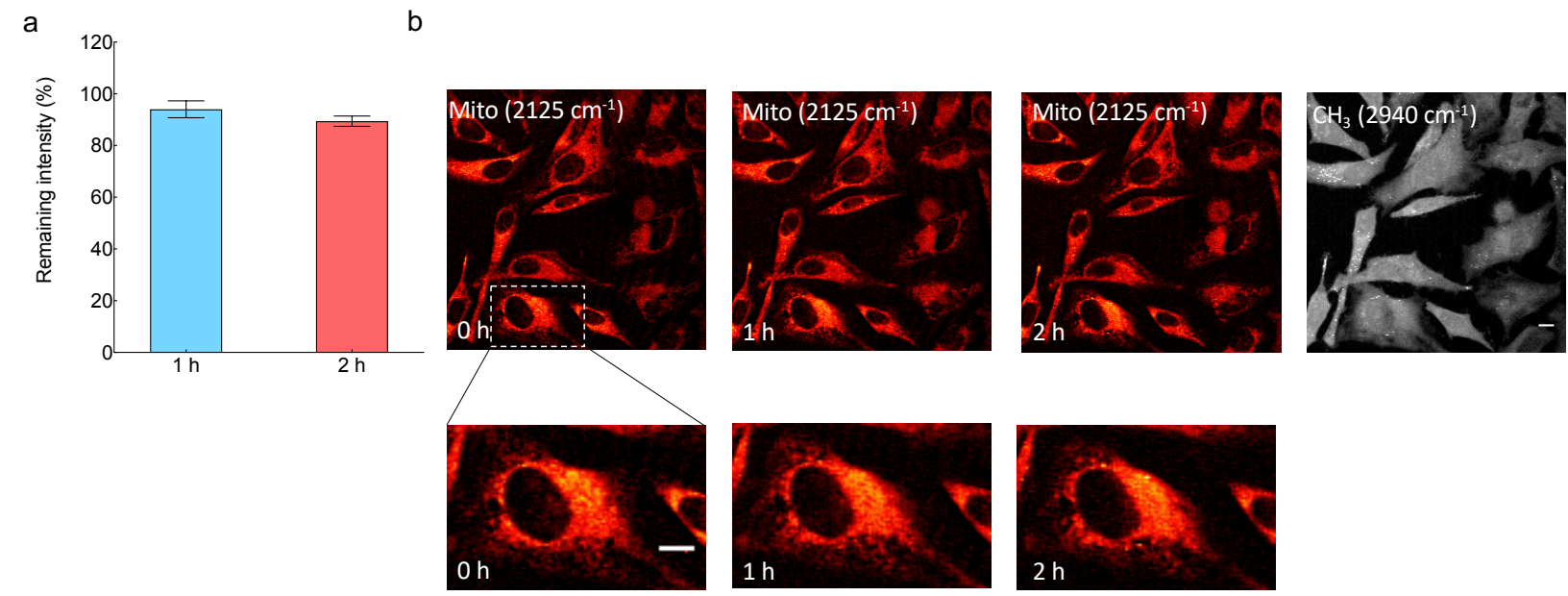

Figure S14. Labeling signal and specificity evaluation during 2 hours of time lapse imaging in photoactivated Me-Mito- ${ }^{13} \mathrm{C}$ (16) labeled live HeLa cells. (a) Quantification of retained signals after 1 hour and 2 hours imaging. The values of signals at $0 \mathrm{~h}$ were used as $100 \%$ signal reference. $\mathrm{n}=6$ independent experiments. Data shown as mean \pm SEM. (b) A series of representative time lapse imaging. The magnified images of the bottom cell (indicated by the dashed white box) are shown. Scale bar: $10 \mu \mathrm{m}$. 


\section{References:}

(1) Komatsu, K.; Arai, M.; Hattori, Y.; Fukuyama, K. Reaction of 1,8-Bis(Phenylethynyl)Naphthalene with Phenylchlorocarbene: Formation of an Intramolecular Cyclization Product from the Car Bene Monoadduct and of 1,8-Naphthylenebis(Diphenylcyclopropenylium) Dication from the Bisadduct. J. Org. Chem. 1987, 22 (52), 2183-2192.

(2) Nielsen, A.; Kuzmanich, G.; Garcia-Garibay, M. A. Quantum Chain Reaction of Tethered Diarylcyclopropenones in the Solid State and Their Distance-Dependence in Solution Reveal a Dexter S2-S 2 Energy-Transfer Mechanism. J. Phys. Chem. A 2014, 118 (10), 1858-1863. https://doi.org/10.1021/jp501216z.

(3) Buckley, D. L.; Raina, K.; Darricarrere, N.; Hines, J.; Gustafson, J. L.; Smith, I. E.; Miah, A. H.; Harling, J. D.; Crews, C. M. HaloPROTACS: Use of Small Molecule PROTACs to Induce Degradation of HaloTag Fusion Proteins. ACS Chem. Biol. 2015, 10 (8), 1831-1837. https://doi.org/10.1021/acschembio.5b00442.

(4) Bassetto, M.; Leyssen, P.; Neyts, J.; Yerukhimovich, M. M.; Frick, D. N.; Courtney-Smith, M.; Brancale, A. In Silico Identification, Design and Synthesis of Novel Piperazine-Based Antiviral Agents Targeting the Hepatitis C Virus Helicase. Eur. J. Med. Chem. 2017, 125, 1115-1131. https://doi.org/10.1016/j.ejmech.2016.10.043. 


\section{NMR and HRMS spectra:}

File: 081020.01 Sample: Sample C17H10O m/z 230 HR FAB NBA

Instrument:

Inlet: My Inlet

Jiajun Du lonization mode: FAB+

R.T.: 1.17

Scan: $14-15$

Base: $\mathrm{m} / \mathrm{z} 231 ; 100 \%$ FS TIC: 19866664

Selected Isotopes: $\mathrm{CHO}_{0.2}$

Measured Mass \% Base Formula

$231.0838 \quad 100.0 \% \quad \mathrm{C}_{17} \mathrm{H}_{11} \mathrm{O}$

Calculated Mass

231.0810

$(M+H)^{+}$
R.T.: 1.17

Scan: 14-15

Base: $\mathrm{m} / \mathrm{z} 231$; 100\%FS TIC: 19866664

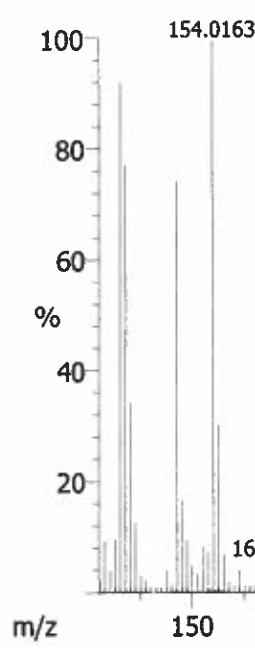

2310838 M+H

231.0838 \#lons: 2588

Unsaturation Limits : 0 to 50

Error Unsaturation

$2.8 \quad 12.5$

\#lons: 2588 

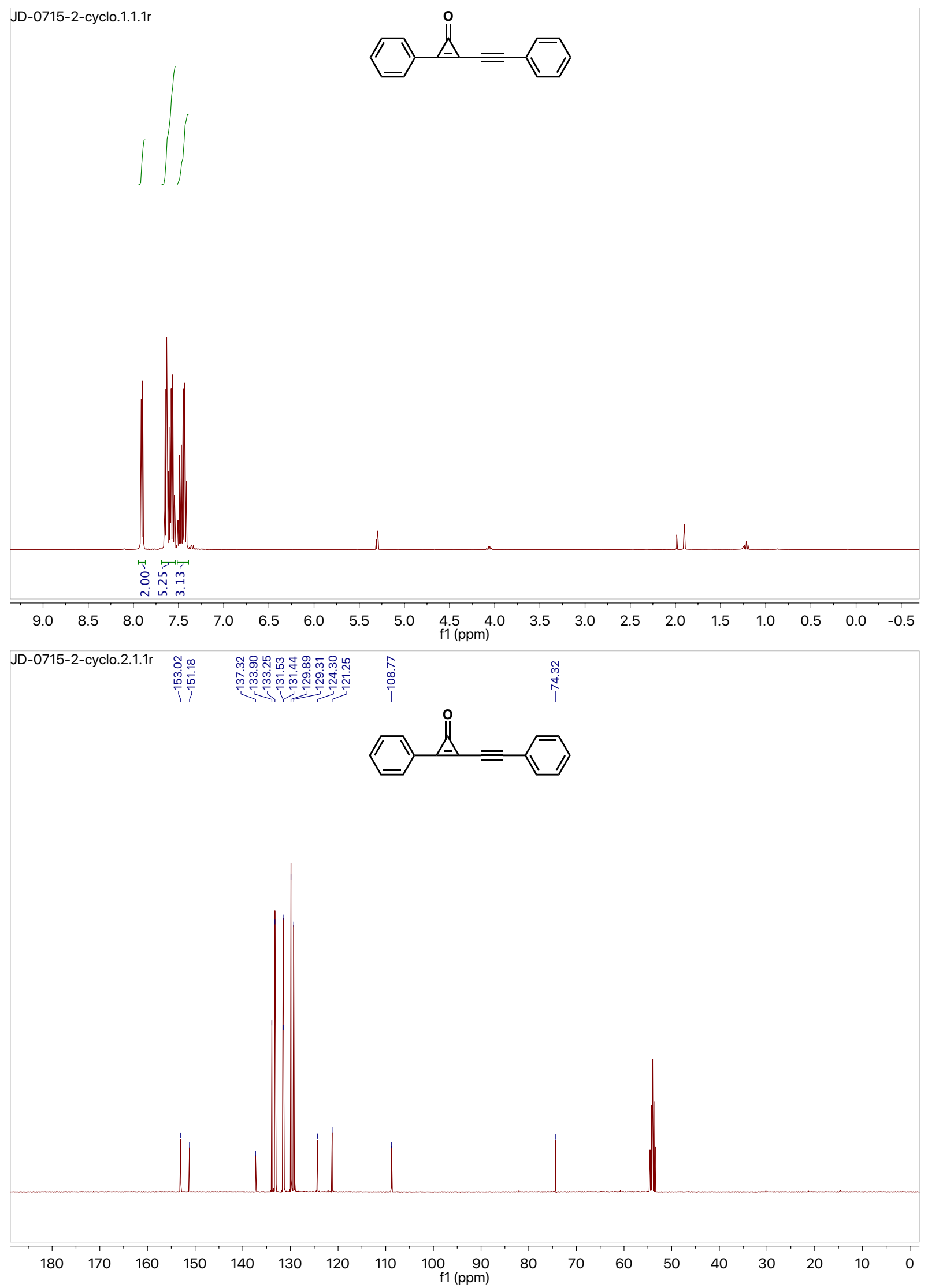
Figure A1. HRMS, ${ }^{1} \mathrm{H}$ NMR (400 MHz, $\left.\mathrm{CD}_{2} \mathrm{Cl}_{2}\right)$ and ${ }^{13} \mathrm{C} \mathrm{NMR}\left(400 \mathrm{MHz}, \mathrm{CD}_{2} \mathrm{Cl}_{2}\right)$ spectra of 2-cyclo (3).

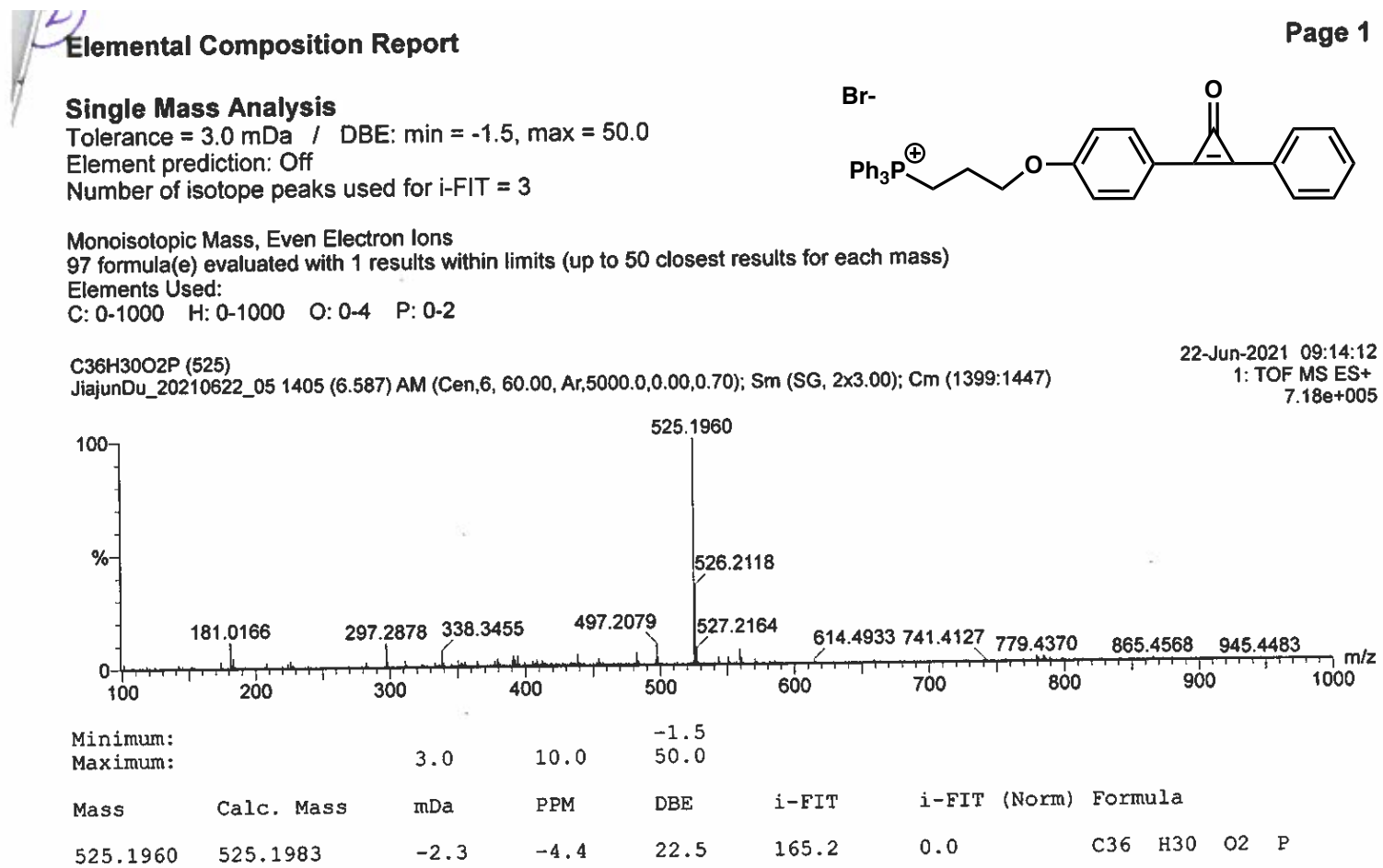




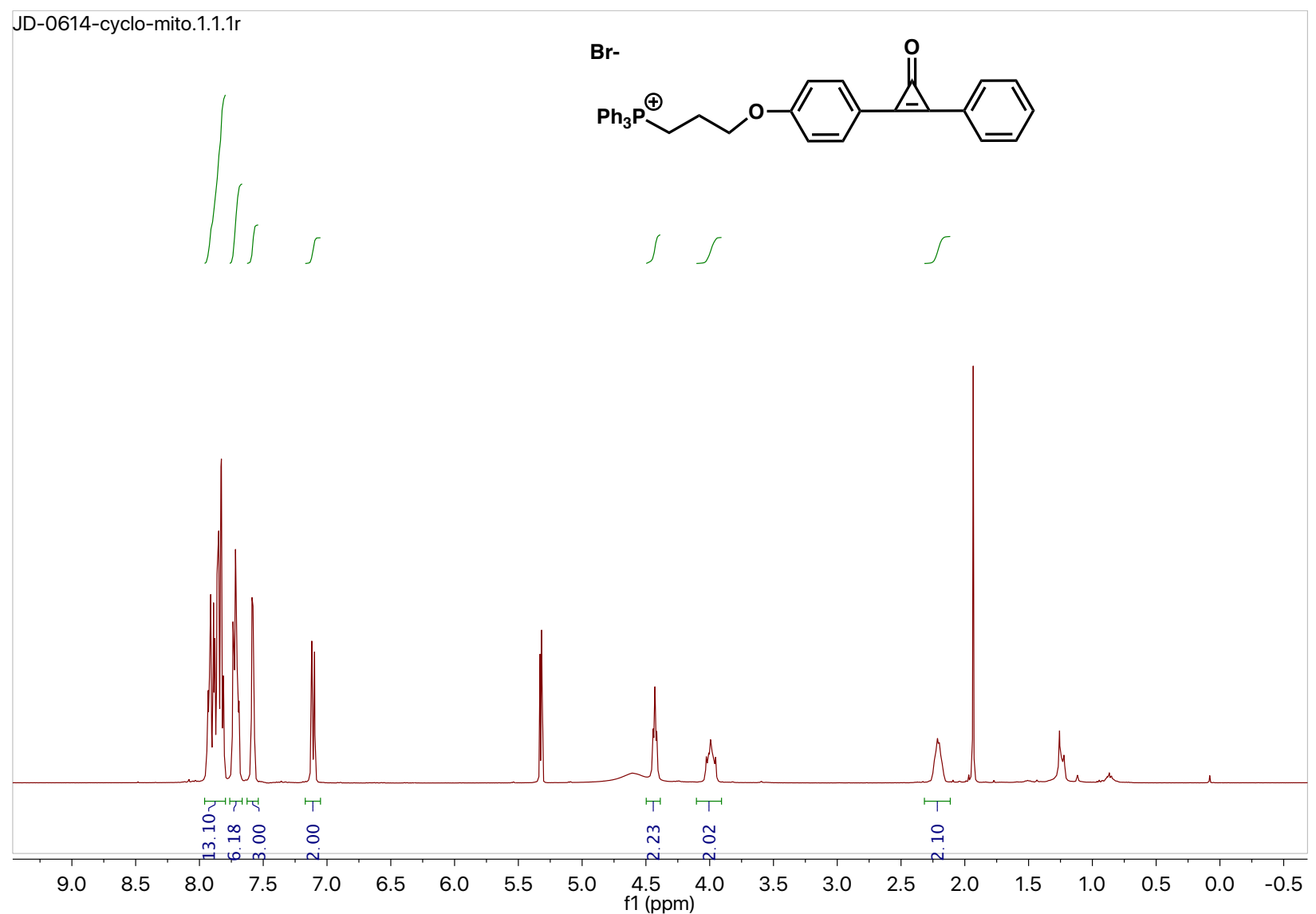

Figure A2. HRMS and ${ }^{1} \mathrm{H}$ NMR (400 $\mathrm{MHz}, \mathrm{CD}_{2} \mathrm{Cl}_{2}$ ) spectra of Cyclo-Mito (7). 
Single Mass Analysis

Tolerance $=3.0 \mathrm{mDa} / \mathrm{DBE}: \min =-1.5, \max =50.0$

Element prediction: Off

Number of isotope peaks used for $\mathrm{i}-\mathrm{FIT}=3$

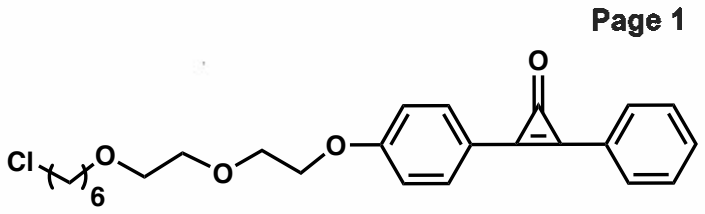

Monoisotopic Mass, Even Electron Ions

30 formula(e) evaluated with 1 results within limits (up to 50 closest results for each mass)

Elements Used:

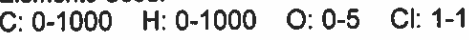

Sample 7 (358)

JiajunDu_20210623_03 1108 (5.301) AM (Cen,8, 50.00, Ar,6000.0,0.00,0.70); Sm (SG, 2×3.00); Cm (1093:1108)

23-Jun-2021 11:27:34

1: TOF MS ES+

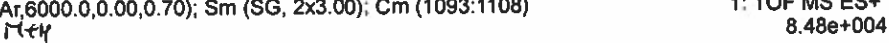

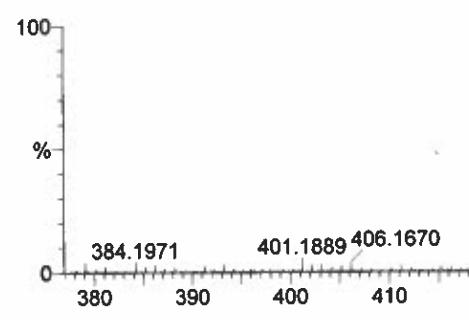

429.1845

Minimum:

Maximun:

3.0

10.0

50.0

Mass

Calc. Mass mDa

PPM

DBE

i-FIT

464.2185

$429.1845 \quad 429.1833$

1.2

2.8

10.5

131.4

469.1760

JD-0604-cyclo-halo.1.1.1r
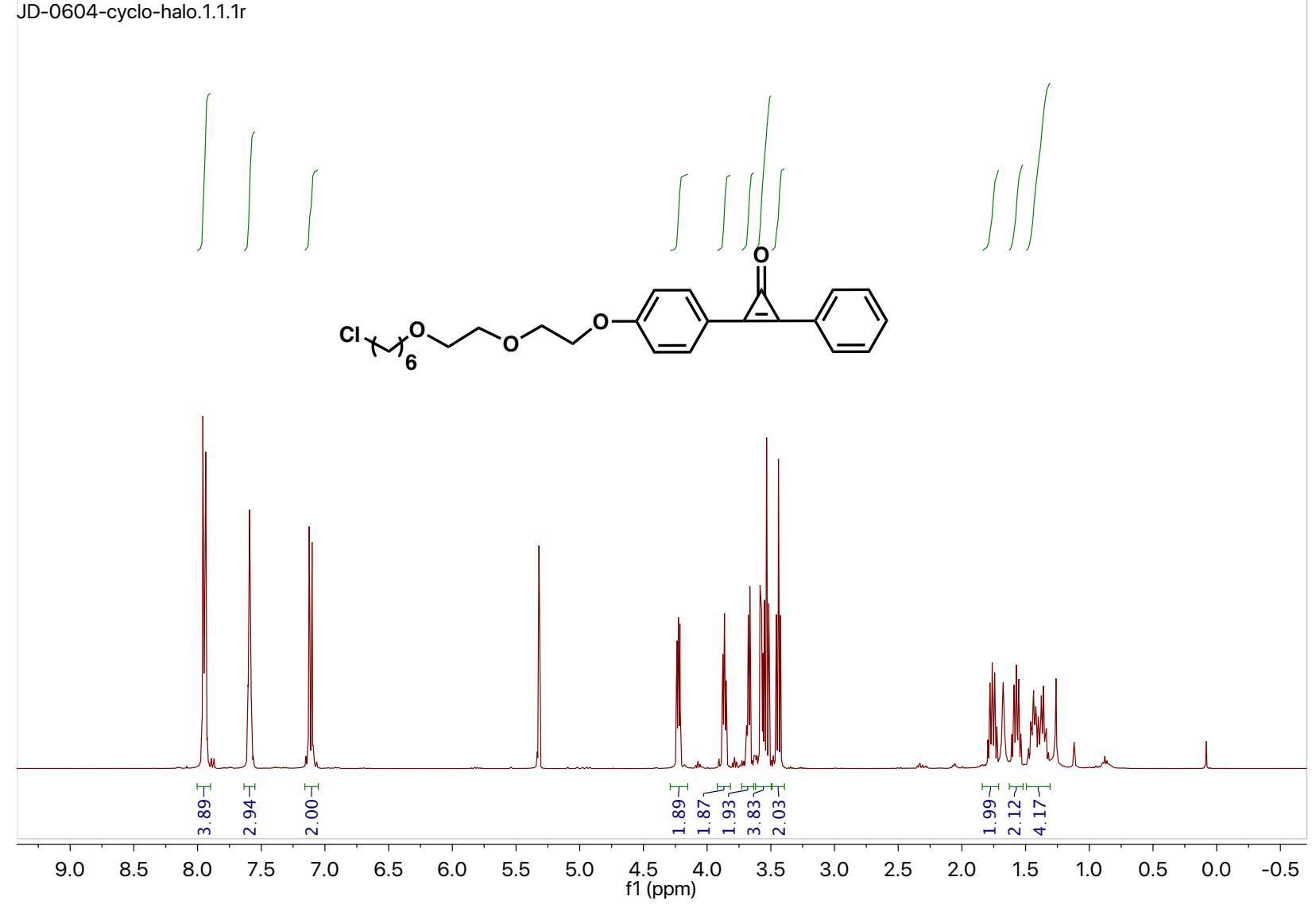

C25 H30 O4 Cl 


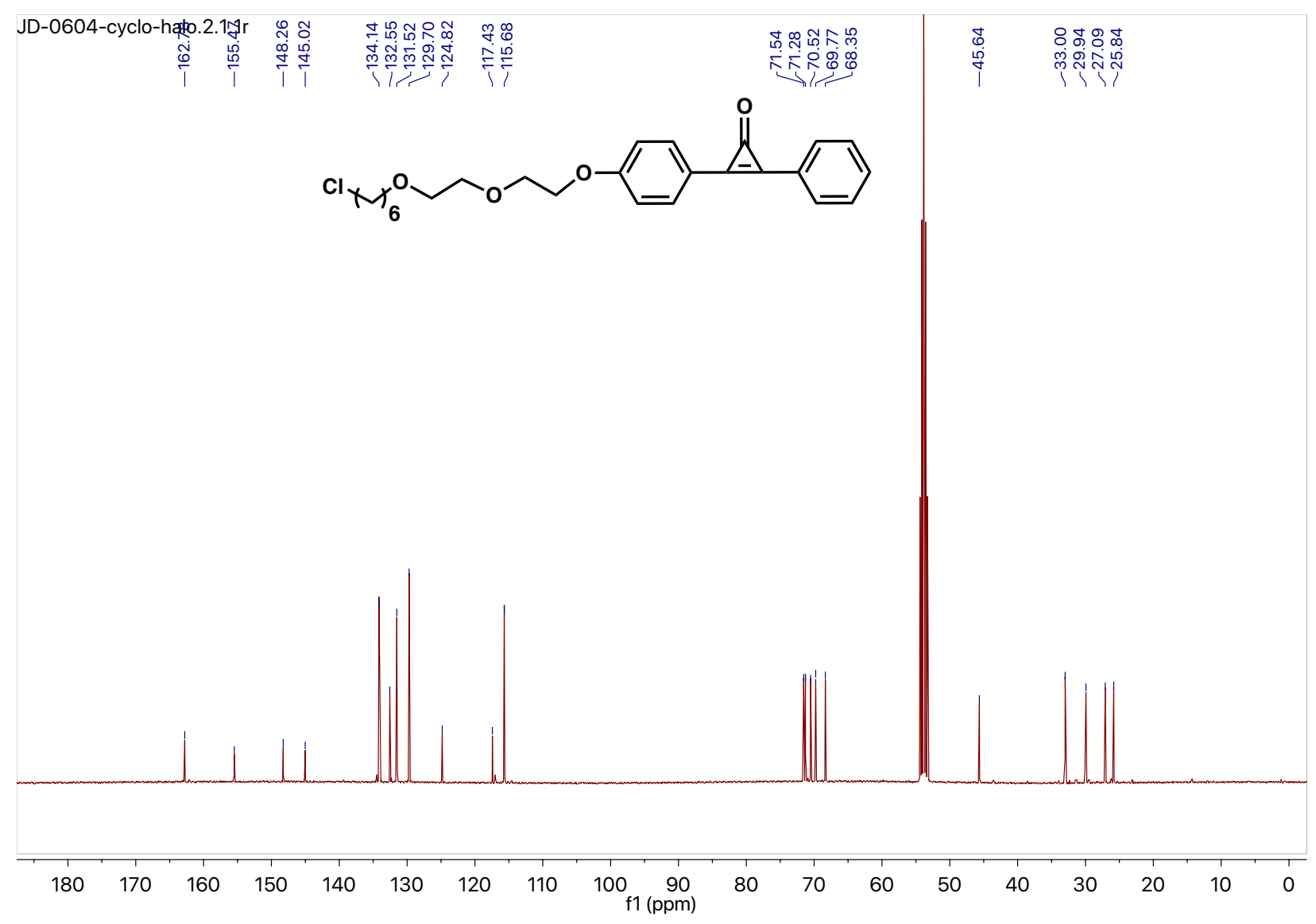

Figure A3. HRMS, ${ }^{1} \mathrm{H} \mathrm{NMR}\left(400 \mathrm{MHz}, \mathrm{CD}_{2} \mathrm{Cl}_{2}\right)$ and ${ }^{13} \mathrm{C} \mathrm{NMR}\left(400 \mathrm{MHz}, \mathrm{CD}_{2} \mathrm{Cl}_{2}\right)$ spectra of Cyclo-LD (17).

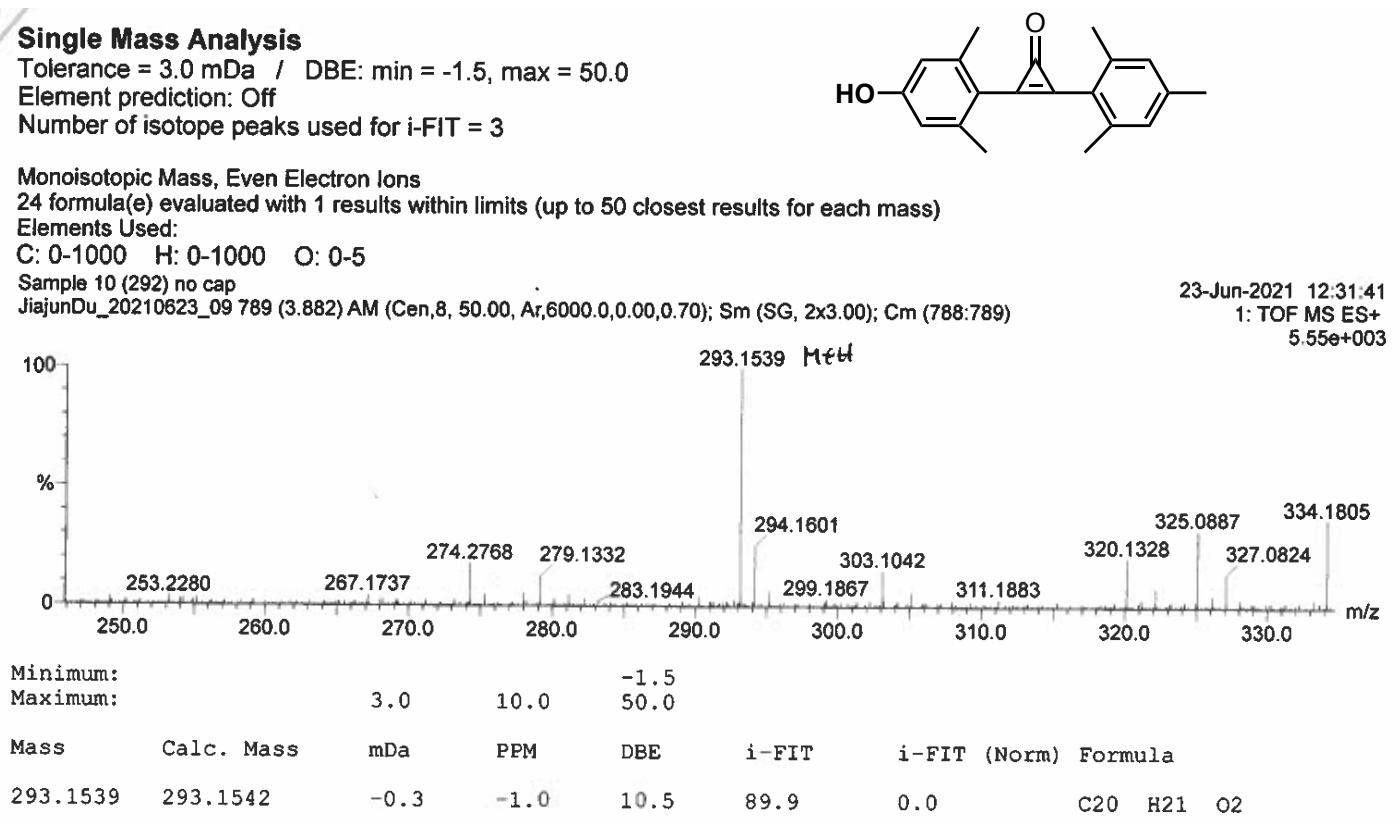




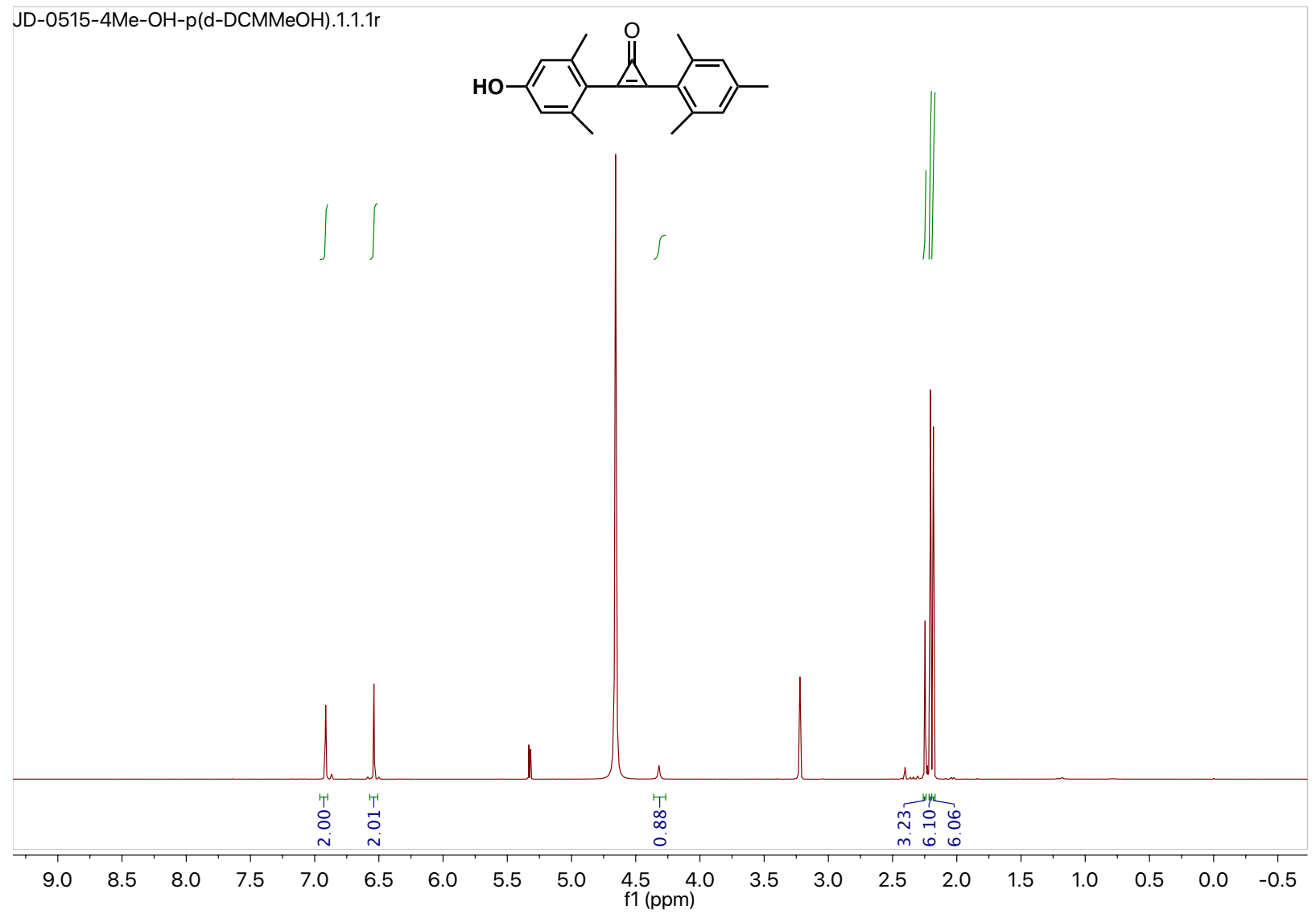

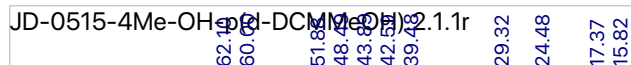
ஸ்

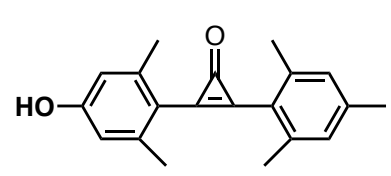

ำกำ

-

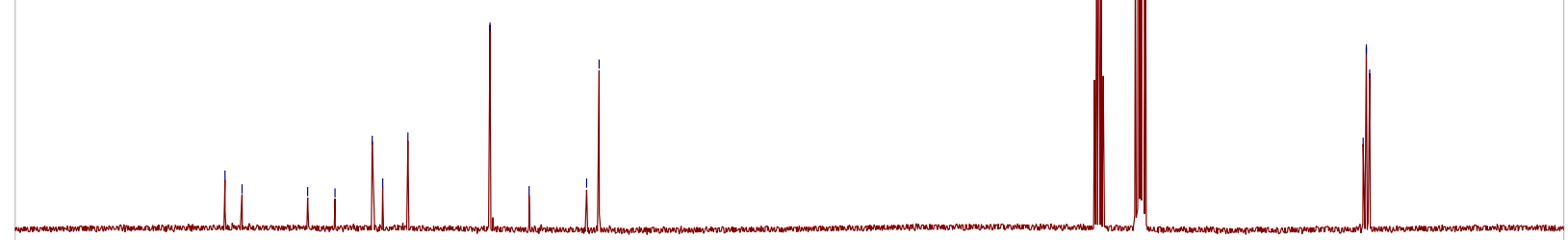


Figure A4. HRMS, ${ }^{1} \mathrm{H}$ NMR (400 MHz, $\mathrm{CD}_{2} \mathrm{Cl}_{2}$ with $\mathrm{CD}_{3} \mathrm{OD}$ as co-solvent) and ${ }^{13} \mathrm{C} \mathrm{NMR}$ (400 $\mathrm{MHz}, \mathrm{CD}_{2} \mathrm{Cl}_{2}$ with $\mathrm{CD}_{3} \mathrm{OD}$ as co-solvent) spectra of $\mathbf{8}$.

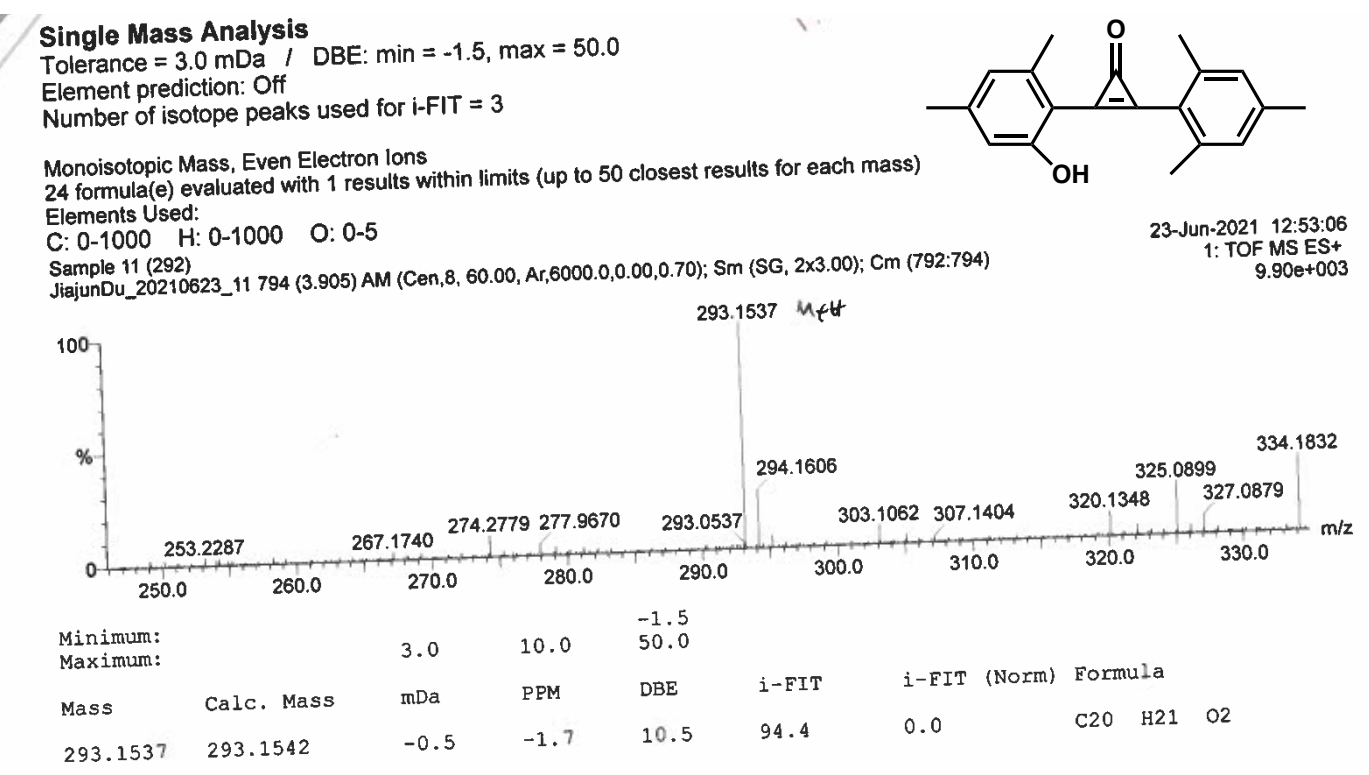




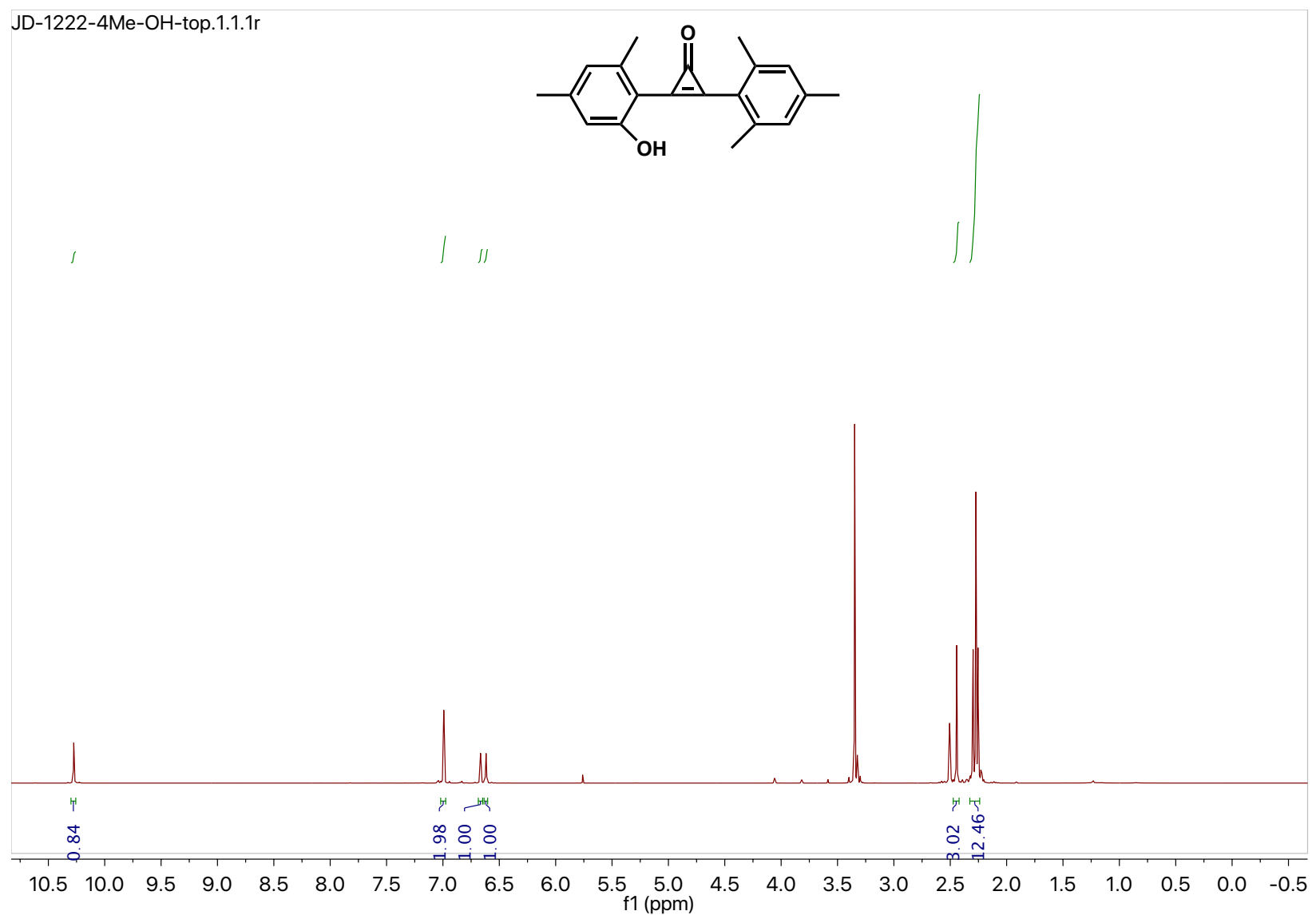

Figure A5. HRMS and ${ }^{1} \mathrm{H}$ NMR (400 $\mathrm{MHz}, \mathrm{CD}_{2} \mathrm{Cl}_{2}$ with $\mathrm{CD}_{3} \mathrm{OD}$ as co-solvent) spectra of the isomer of $\mathbf{8}$. 
Elemental Composition Report

Single Mass Analysis

Tolerance $=3.0 \mathrm{mDa} / \mathrm{DBE}: \min =-1.5, \max =50.0$

Element prediction: Off

Number of isotope peaks used for $\mathrm{i}-\mathrm{FIT}=3$

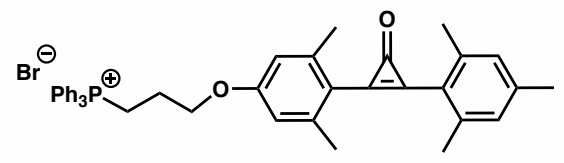

Monoisotopic Mass, Even Electron lons

111 formula(e) evaluated with 1 results within limits (up to 50 closest results for each mass)

Elements Used:

$\begin{array}{llll}\text { C: } 0-1000 & \text { H: } 0-1000 & \text { O: } 0-4 & \text { P: } 0-2\end{array}$

C41H40O2P (595)W

JiajunDu_20210622_08 977 (4.719) AM (Top,6, Ar,5000.0,0.00,0.00); Sm (SG, 2x3.00); Cm (975:978)

22-Jun-2021 09:46:45

1: TOF MS ES+

579.0974

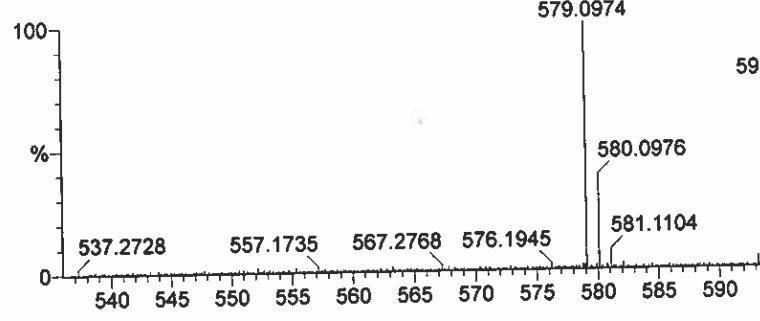

$7.65 \mathrm{e}+003$

\begin{tabular}{|c|c|c|c|c|c|c|c|c|c|c|}
\hline $\begin{array}{l}\text { Minimum: } \\
\text { Maximum: }\end{array}$ & & 3.0 & 10.0 & $\begin{array}{l}-1.5 \\
50.0\end{array}$ & & & & & & \\
\hline Mass & Calc. Mass & $\mathrm{mDa}$ & PPM & $\mathrm{DBE}$ & i-EIT & i-FIT & (Norm) & Formula & & \\
\hline 595.2755 & 595.2766 & -1.1 & -1.8 & 22.5 & 112.3 & 0.0 & & $\mathrm{C} 41 \mathrm{H} 4 \mathrm{O}$ & 02 & $\mathbf{P}$ \\
\hline
\end{tabular}

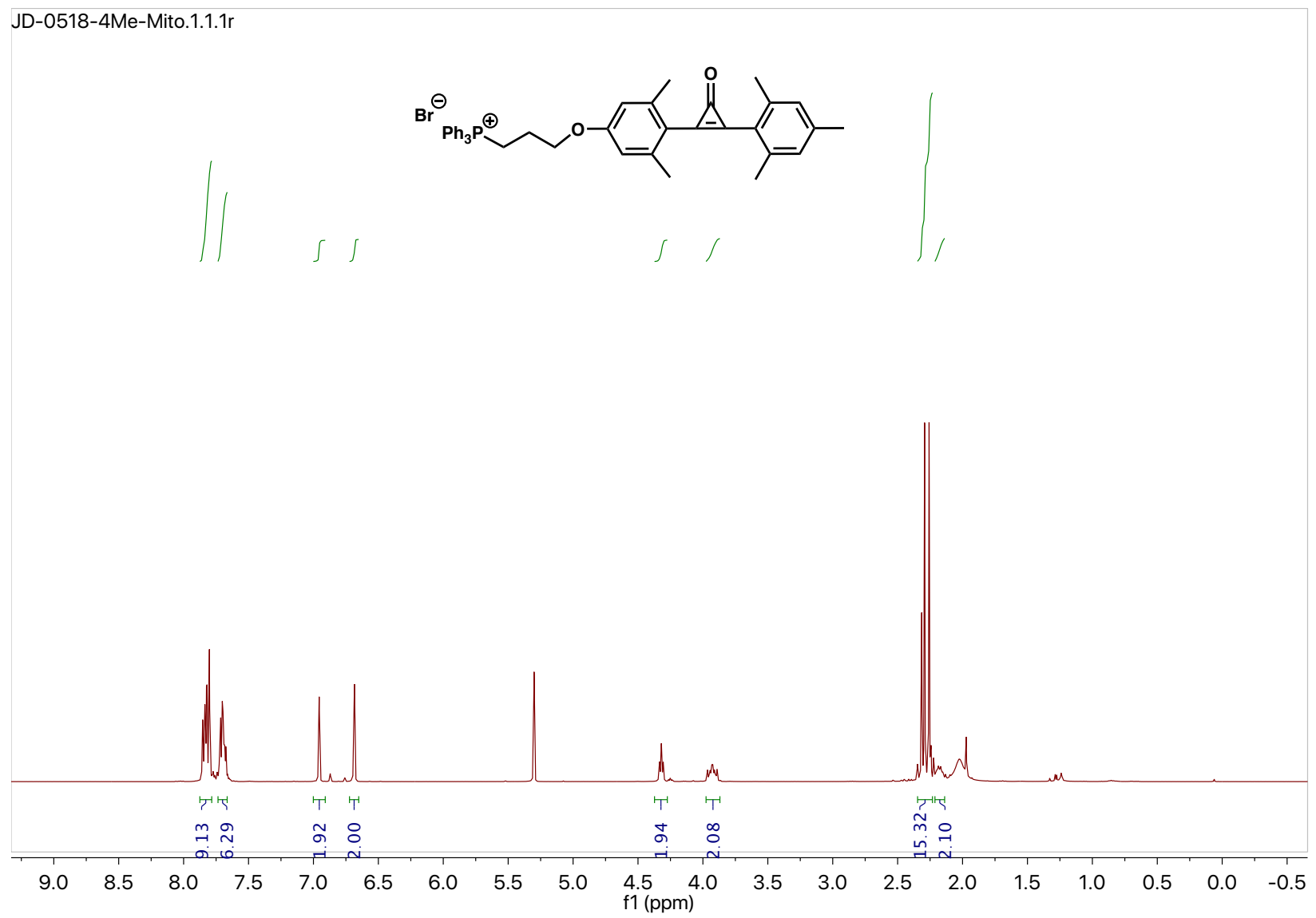




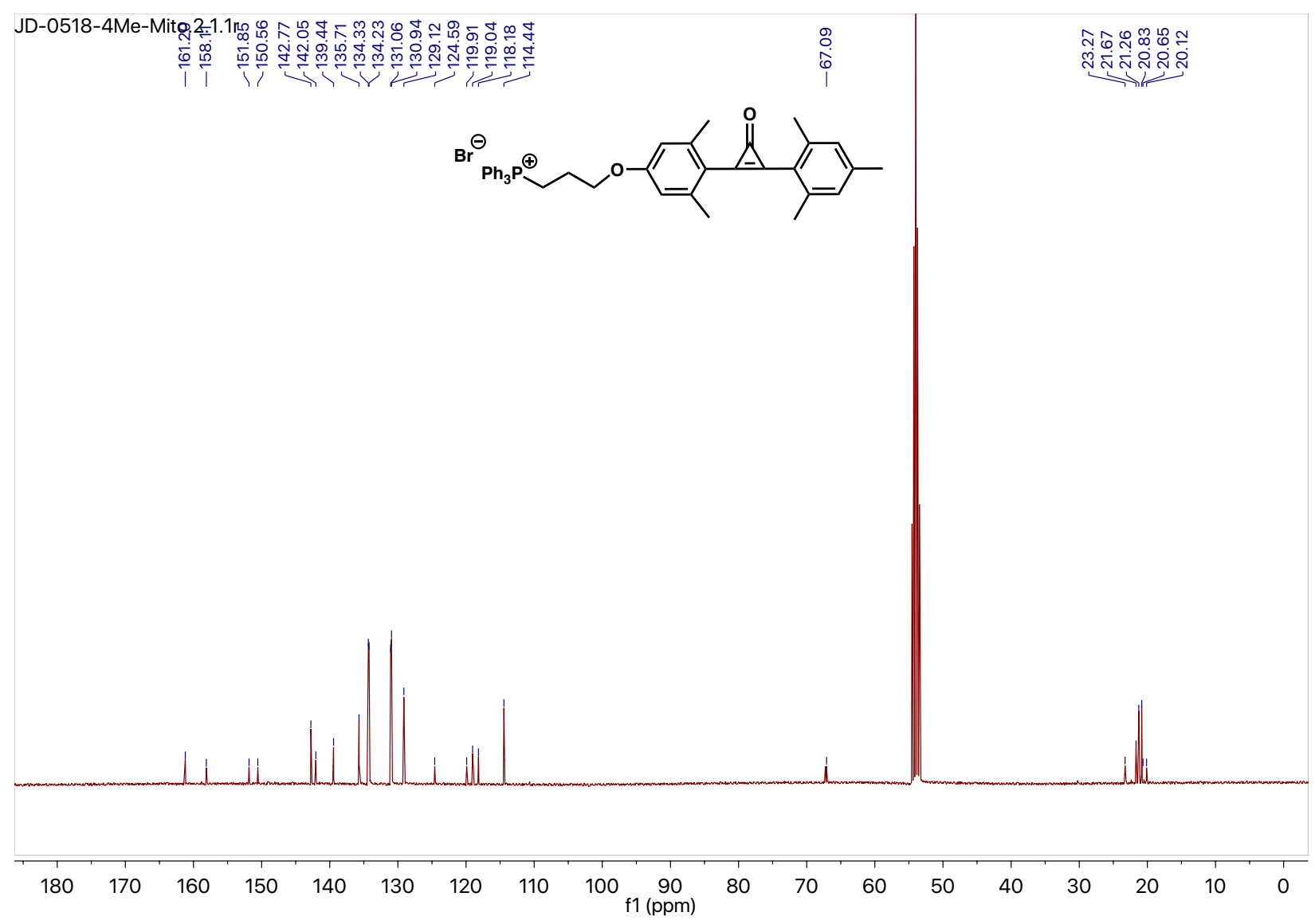

Figure A6. HRMS, ${ }^{1} \mathrm{H} \mathrm{NMR}\left(400 \mathrm{MHz}, \mathrm{CD}_{2} \mathrm{Cl}_{2}\right)$ and ${ }^{13} \mathrm{C} \mathrm{NMR}\left(400 \mathrm{MHz}, \mathrm{CD}_{2} \mathrm{Cl}_{2}\right.$ ) spectra of Me-Mito (12). 
Single Mass Analysis

Tolerance $=3.0 \mathrm{mDa} / \mathrm{DBE}: \min =-1.5, \max =50.0$

Element prediction: Off

Number of isotope peaks used for $\mathrm{i}-\mathrm{FIT}=3$

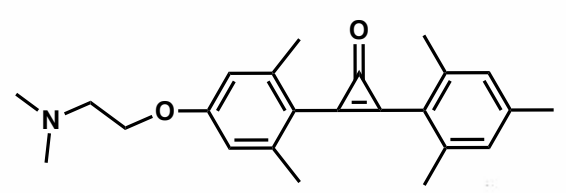

Monoisotopic Mass, Even Electron lons

75 formula(e) evaluated with 1 results within limits (up to 50 closest results for each mass)

Elements Used:

$\begin{array}{llll}\text { C: } 0-1000 & H: 0-1000 & \text { N: } 0-2 & 0: 0-4\end{array}$

C24H29NO2 (363)

JiajunDu_20210622_03 792 (3.903) AM (Cen,6, 50.00, Ar,5000.0,0.00,0.70); Sm (SG, 2×3.00); Cm (787:792)

22-Jun-2021 08:52:40

1: TOF MS ES+

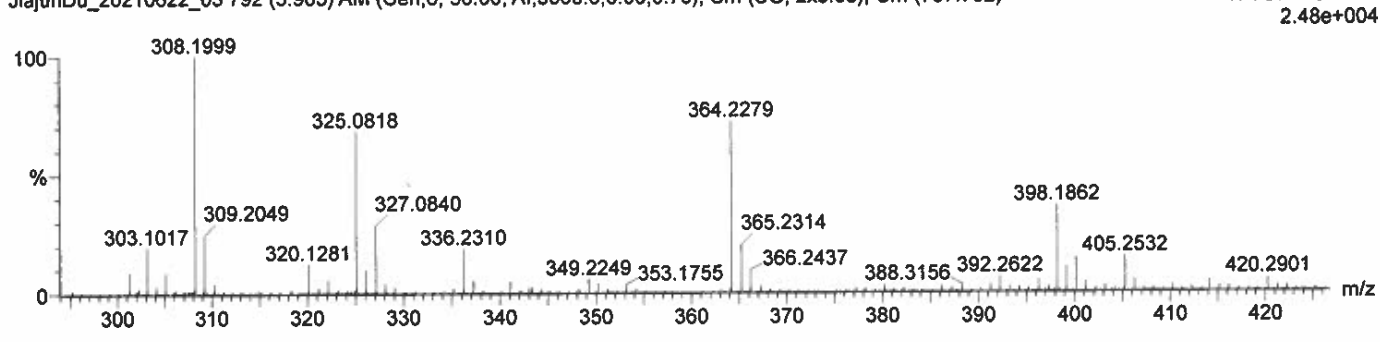

Minimum:

Maximum:

3.0

$10.0 \quad 50.0$

Mass

Calc. Mass

$\mathrm{mDa}$

PPM

DBE

I-EIT

i-FIT (Norm) Formula

$364.2279 \quad 364.227$

0.2

0.5

10.5

158.5

0.0

$\mathrm{C} 24 \quad \mathrm{H} 30 \quad \mathrm{~N} \quad \mathrm{O} 2$

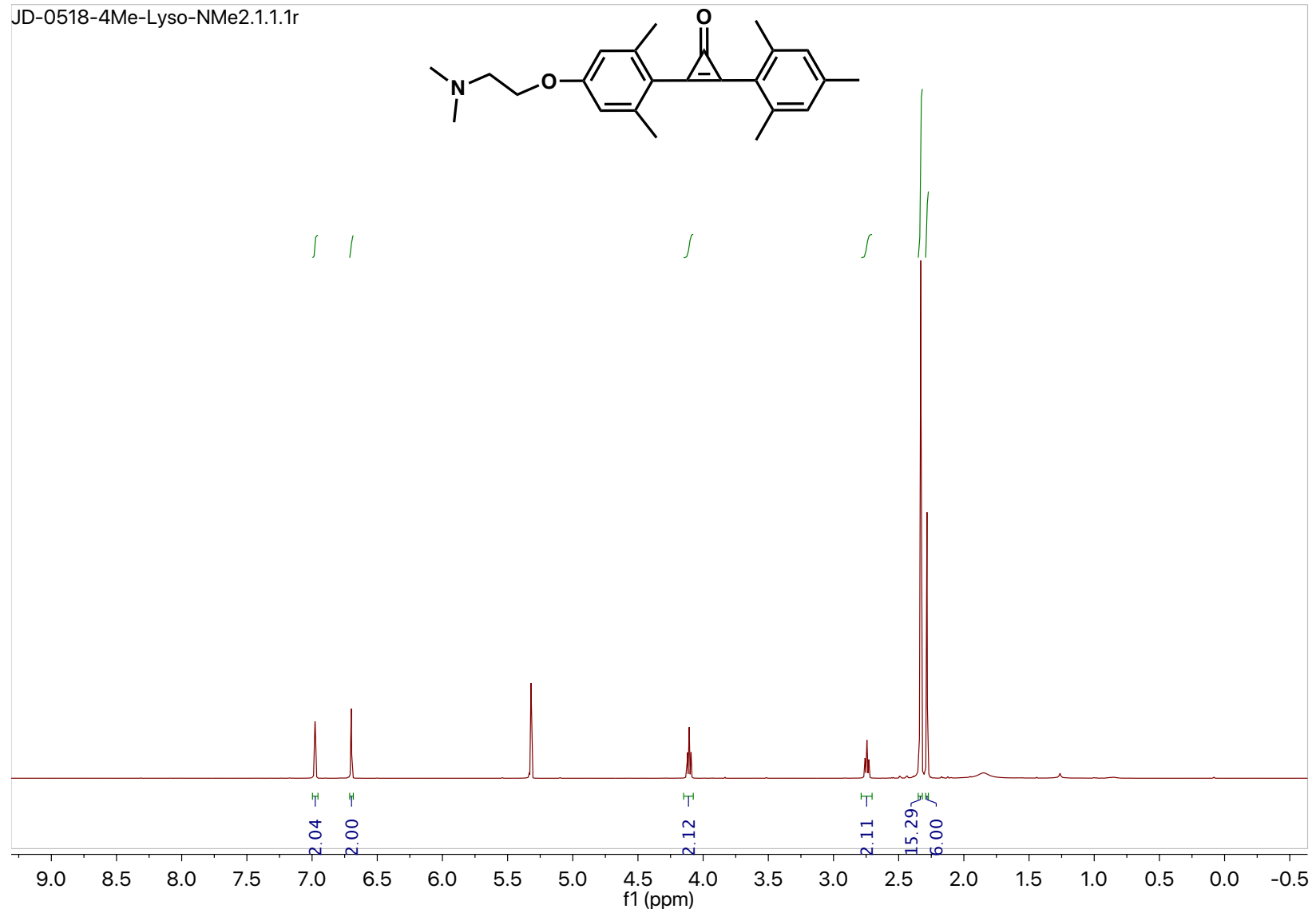




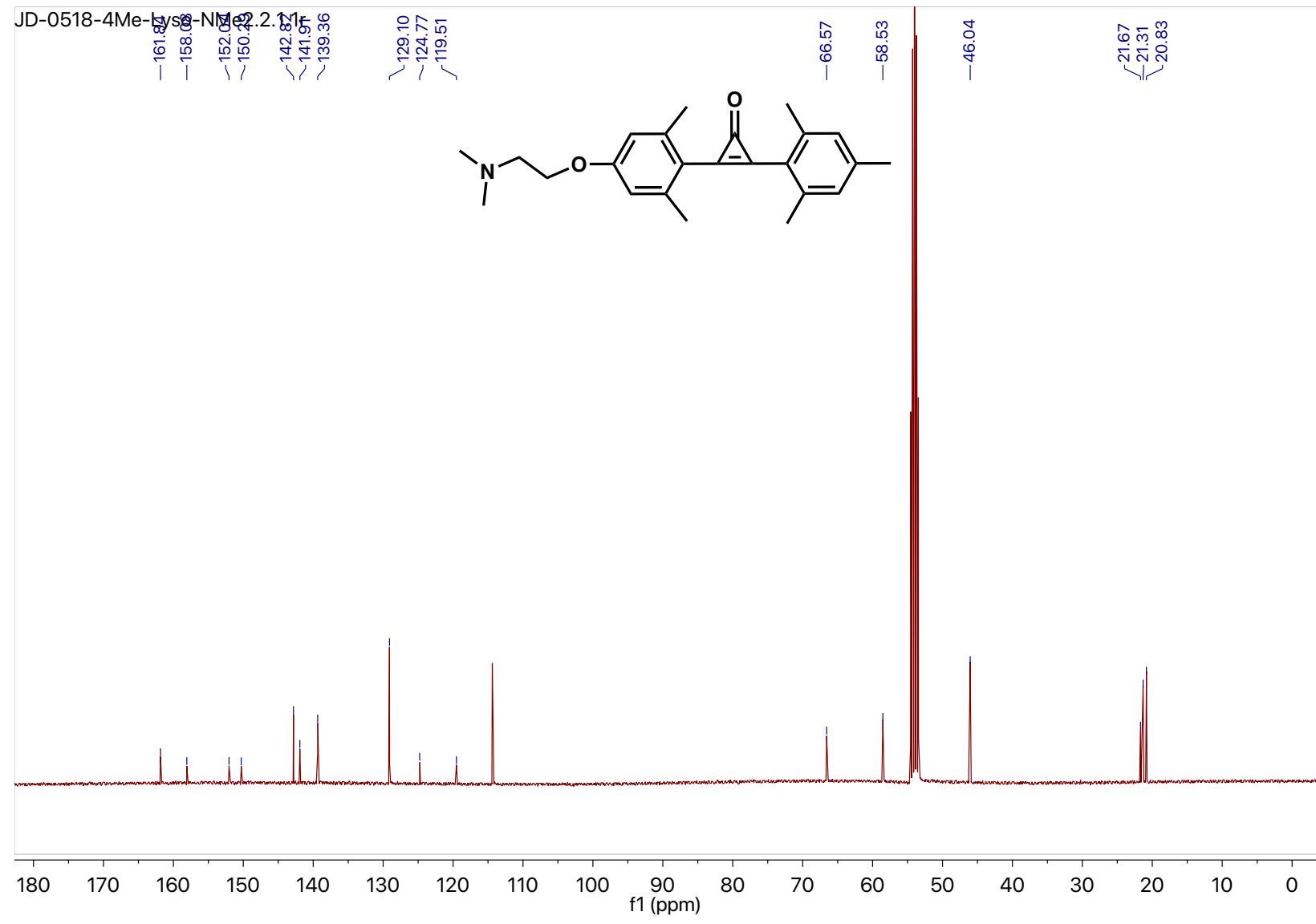

Figure A7. HRMS, ${ }^{1} \mathrm{H} \mathrm{NMR}\left(400 \mathrm{MHz}, \mathrm{CD}_{2} \mathrm{Cl}_{2}\right)$ and ${ }^{13} \mathrm{C} \mathrm{NMR}\left(400 \mathrm{MHz}, \mathrm{CD}_{2} \mathrm{Cl}_{2}\right)$ spectra of Me-Lyso (13). 

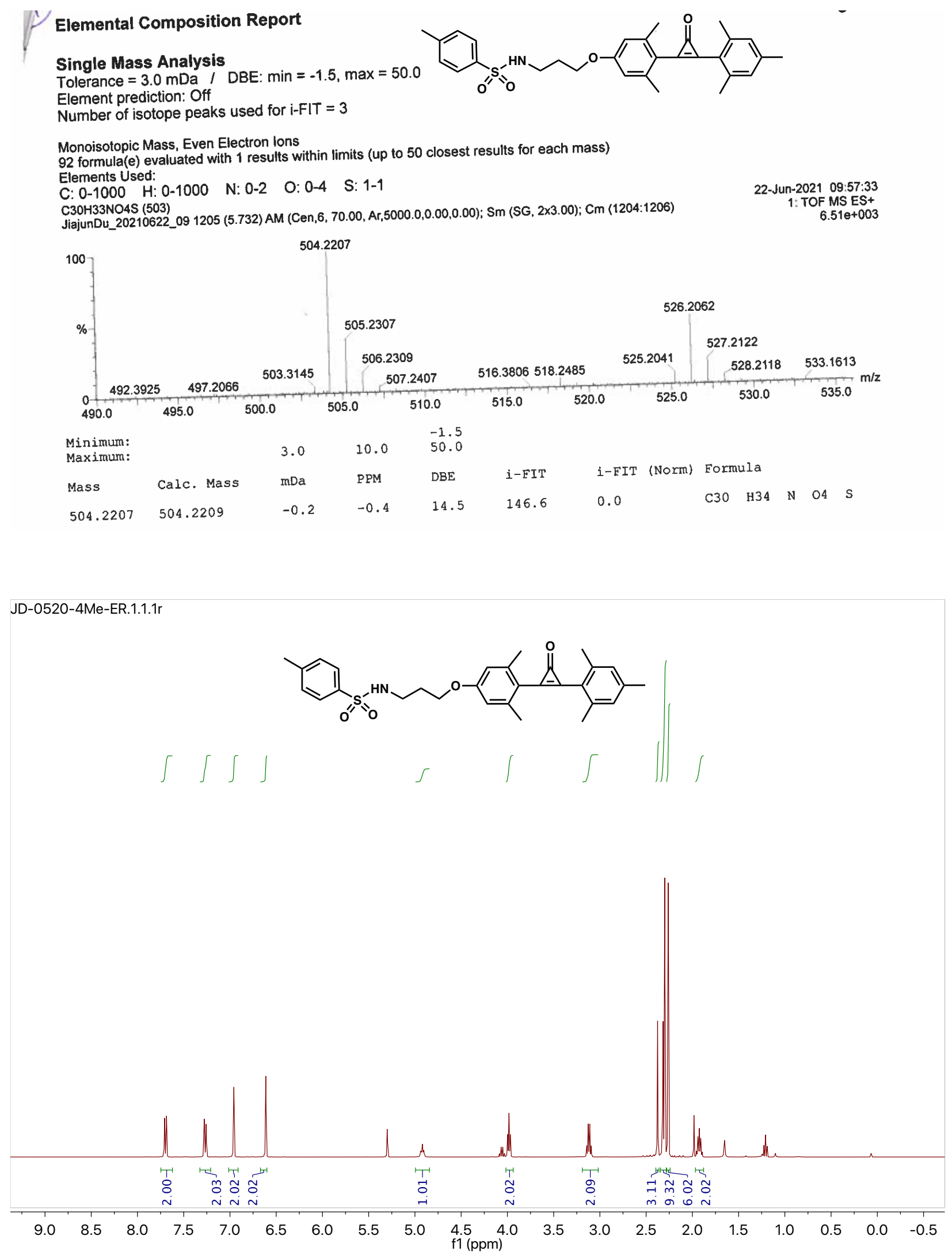


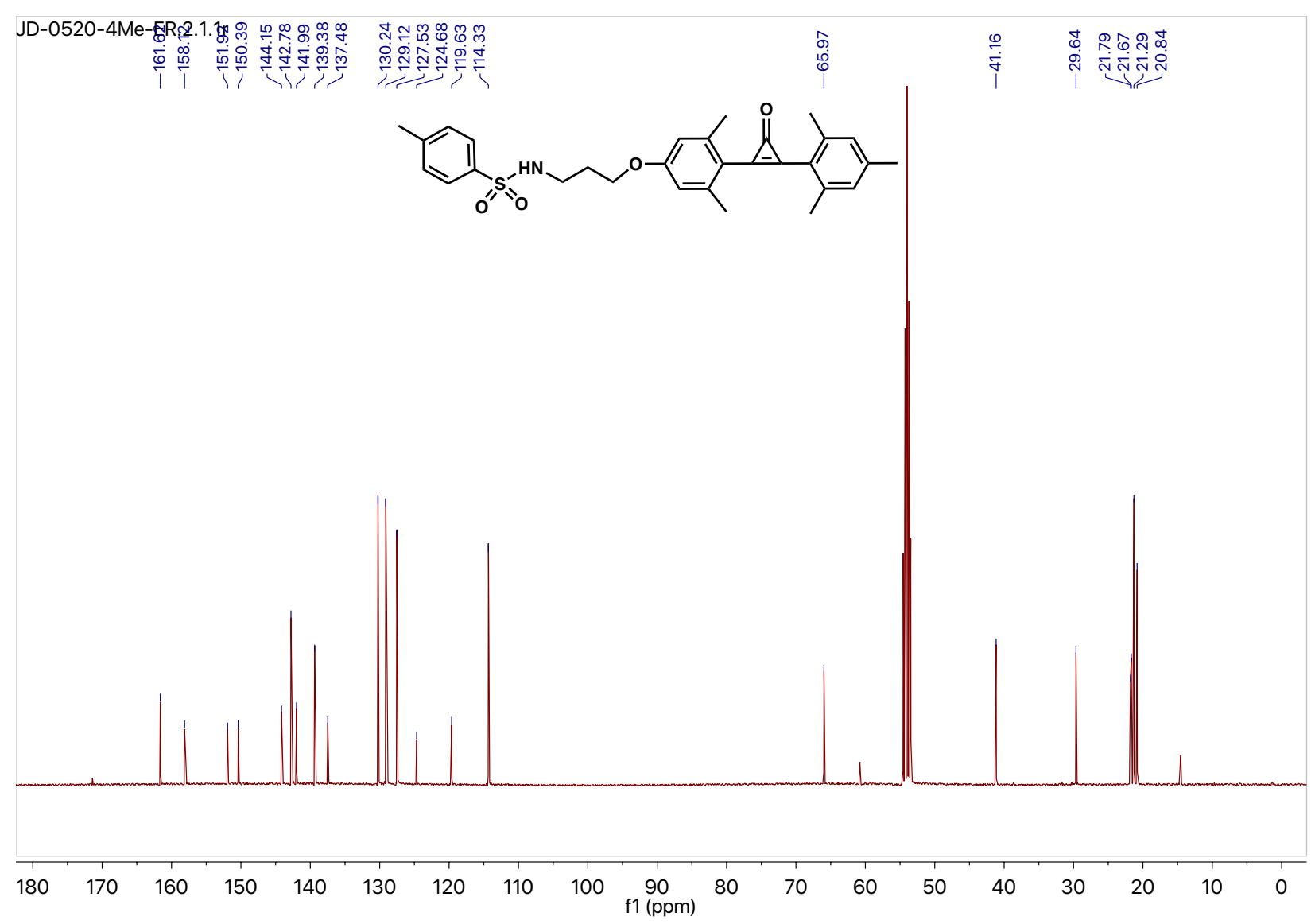

Figure A8. HRMS, ${ }^{1} \mathrm{H} \mathrm{NMR}\left(400 \mathrm{MHz}, \mathrm{CD}_{2} \mathrm{Cl}_{2}\right)$ and ${ }^{13} \mathrm{C} \mathrm{NMR}\left(400 \mathrm{MHz}, \mathrm{CD}_{2} \mathrm{Cl}_{2}\right)$ spectra of Me-ER (14). 
Single Mass Analysis

Tolerance $=3.0 \mathrm{mDa} / \mathrm{DBE}: \min =-1.5, \max =50.0$

Element prediction: Off

Number of isotope peaks used for $\mathrm{i}-\mathrm{FIT}=3$

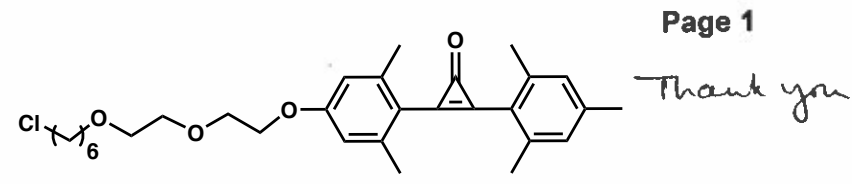

Monoisotopic Mass, Even Electron lons

36 formula(e) evaluated with 1 results within limits (up to 50 closest results for each mass)

$\begin{array}{lll}\text { Elements Used: } & \text { O-1000 } 0-5 \quad \mathrm{Cl}: 1-1\end{array}$

Sample 6 (428)

JiajunDu_20210623_01 1428 (6.719) AM (Cen,8, 50.00, Ar,6000.0,0.00,0.70); Sm (SG, 2×3.00); Cm (1428:1432)

23-Jun-2021 11:06:04

1: TOF MS ES+

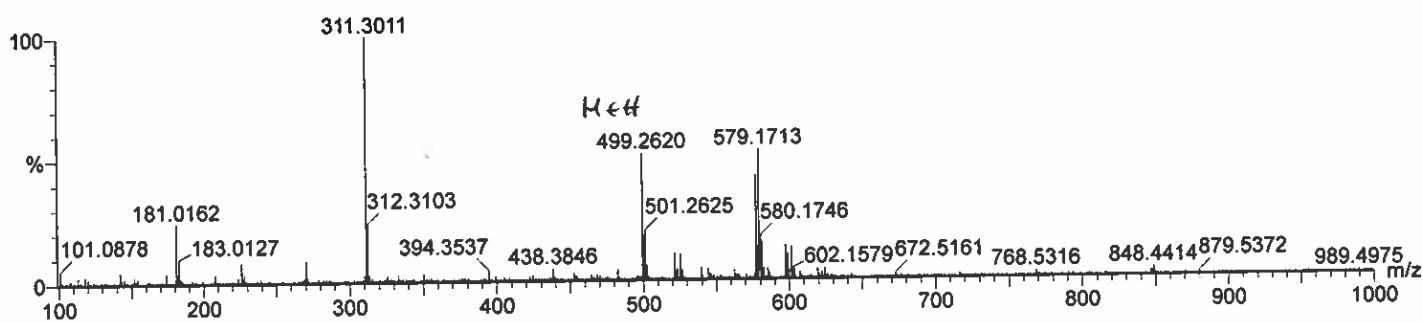

Minimum:

Maximum:

$-1.5$

\section{Mass}

3.0

10.0

50.0

499.2620

Calc. Mass

$\mathrm{mDa}$

PPM

DBE

i-FIT

i-EIT (Norm) Formula

0.5

1.0

10.5

86.6

0.0

C30 $\mathrm{H} 40 \quad \mathrm{O} 4 \mathrm{Cl}$

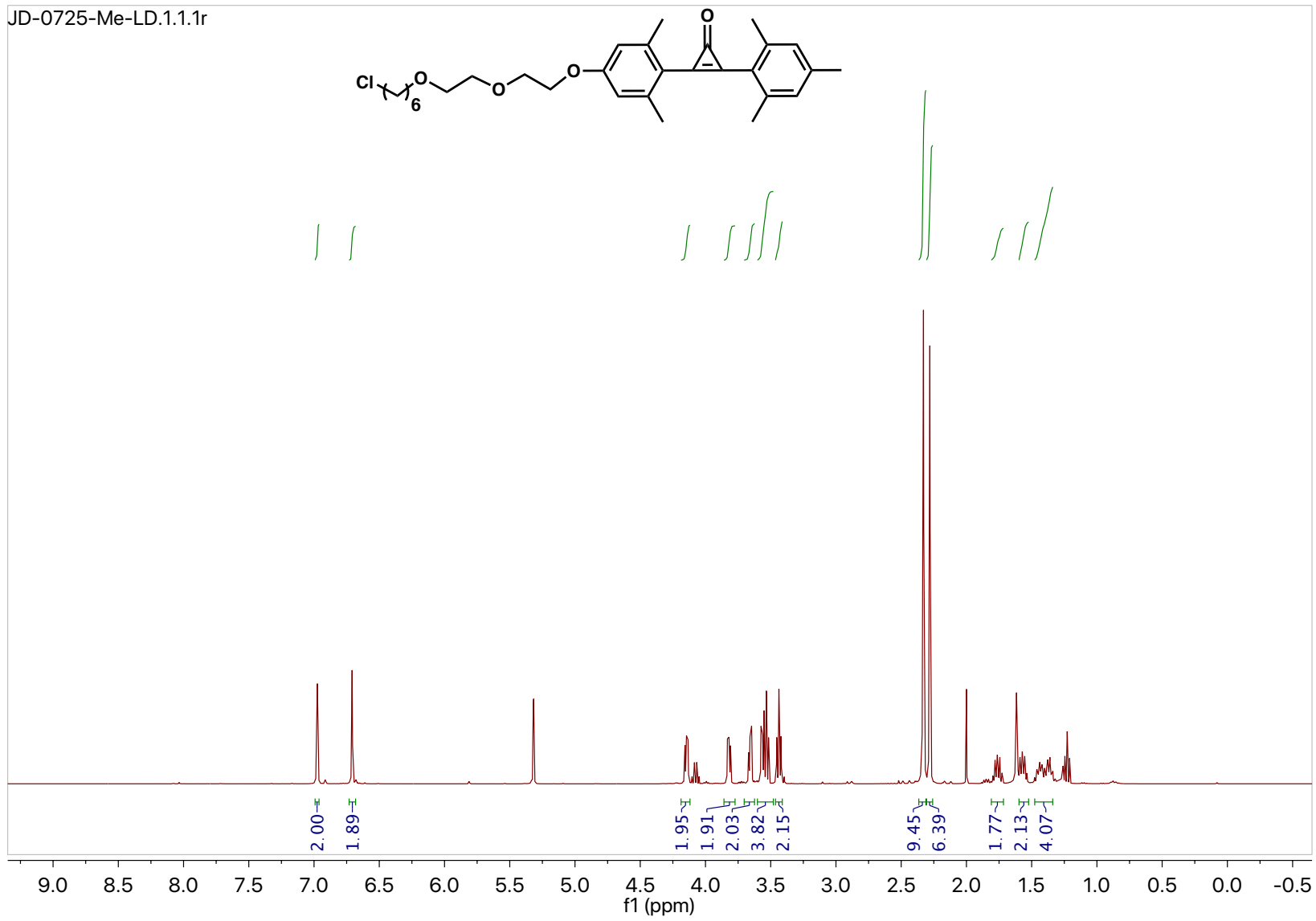




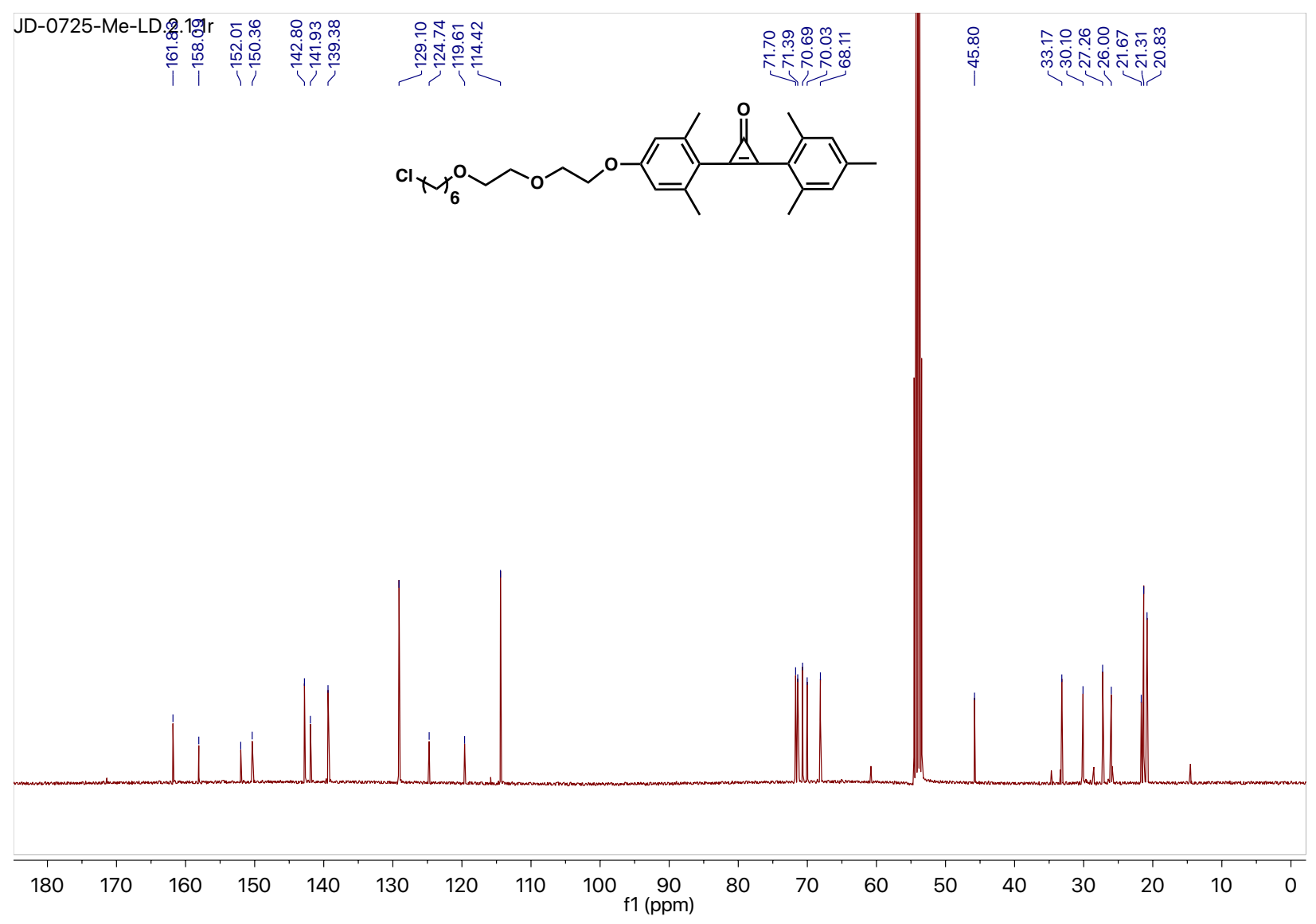

Figure A9. HRMS, ${ }^{1} \mathrm{H} \mathrm{NMR}\left(400 \mathrm{MHz}, \mathrm{CD}_{2} \mathrm{Cl}_{2}\right)$ and ${ }^{13} \mathrm{C} \mathrm{NMR}\left(400 \mathrm{MHz}, \mathrm{CD}_{2} \mathrm{Cl}_{2}\right)$ spectra of Me-LD (15). 


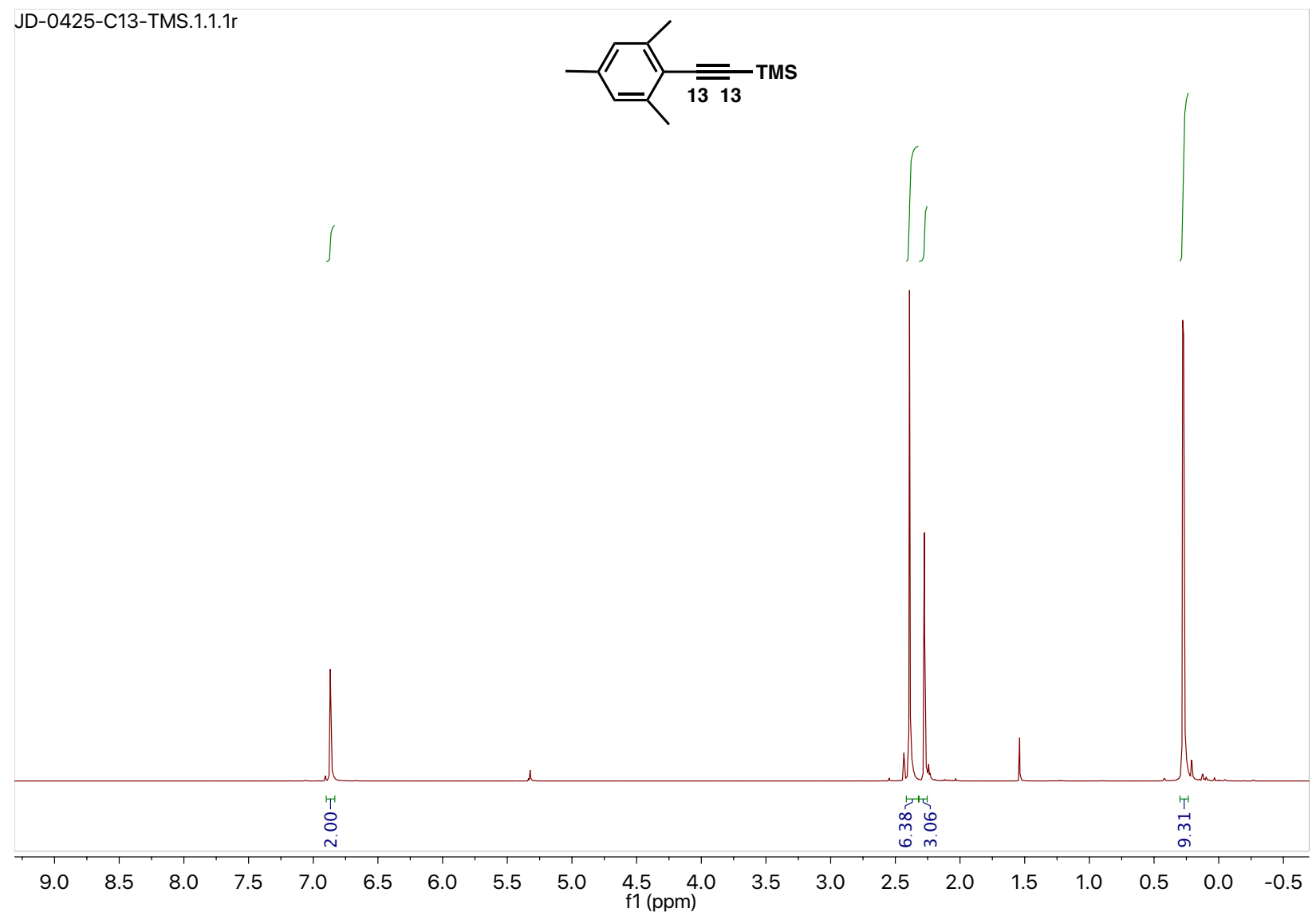




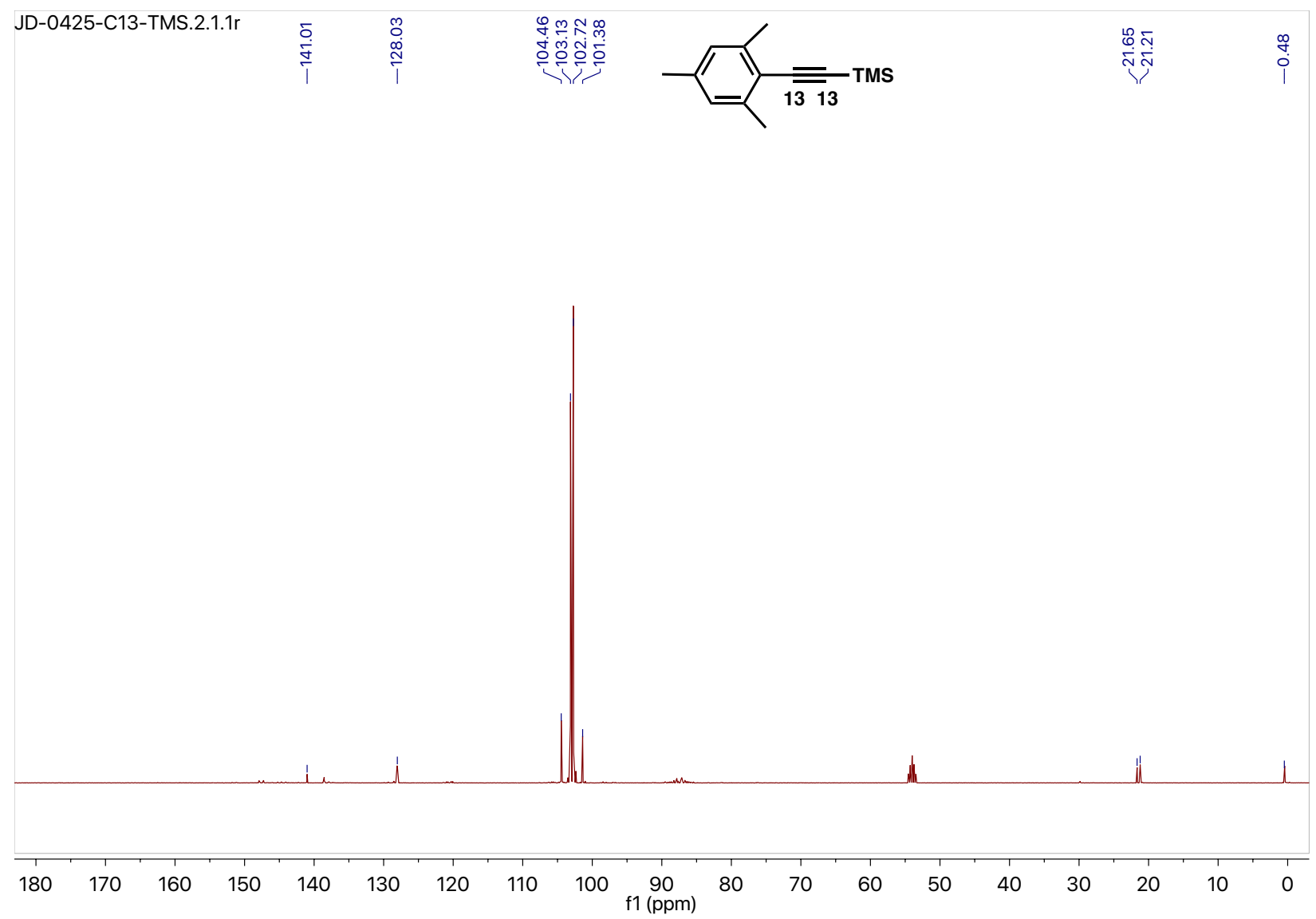

Figure A10. ${ }^{1} \mathrm{H}$ NMR (400 MHz, $\left.\mathrm{CD}_{2} \mathrm{Cl}_{2}\right)$ and ${ }^{13} \mathrm{C} \mathrm{NMR}\left(400 \mathrm{MHz}, \mathrm{CD}_{2} \mathrm{Cl}_{2}\right)$ spectra of I1. 
JD-0425-C13-alkyne.1.1.1r

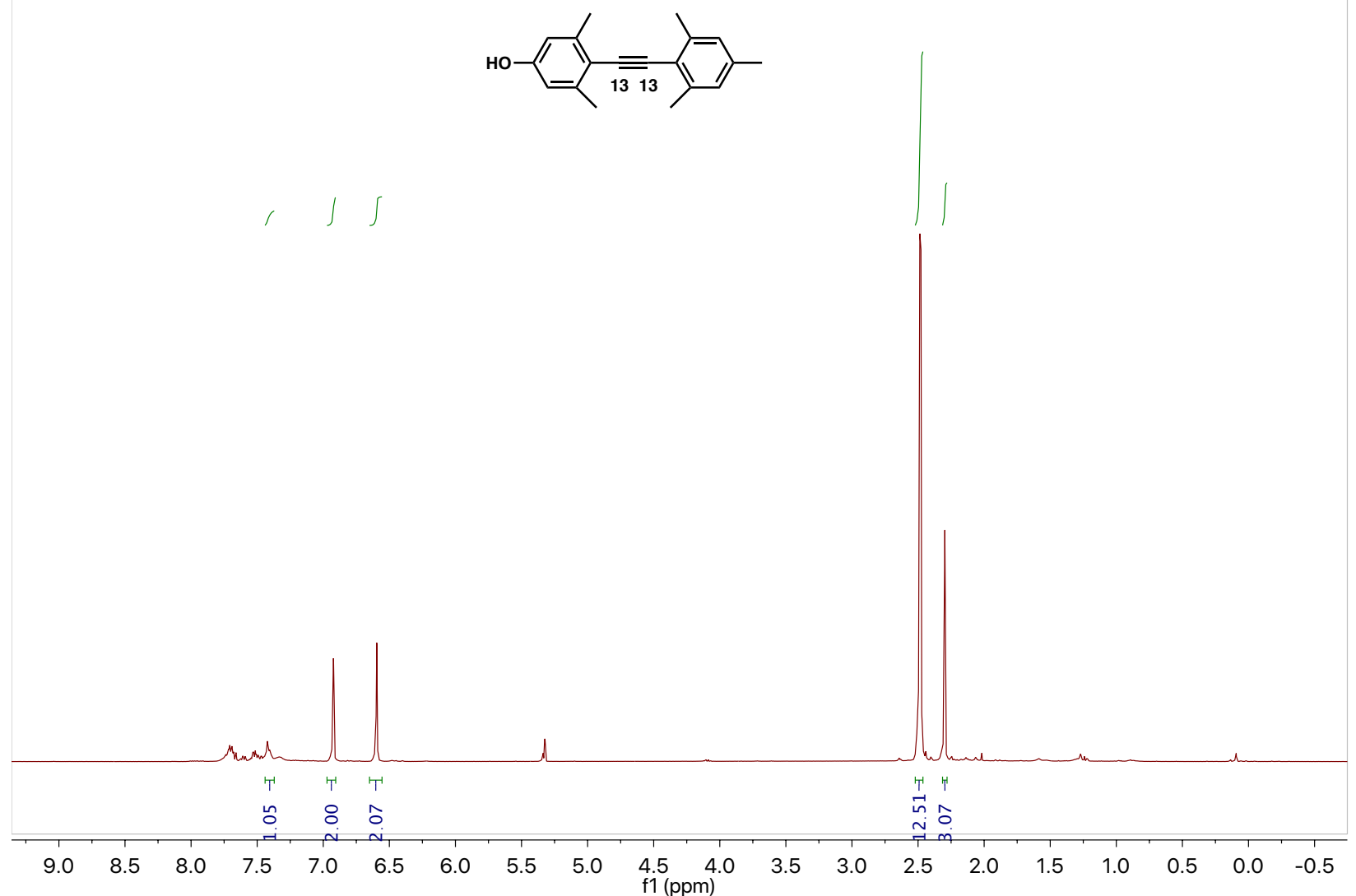




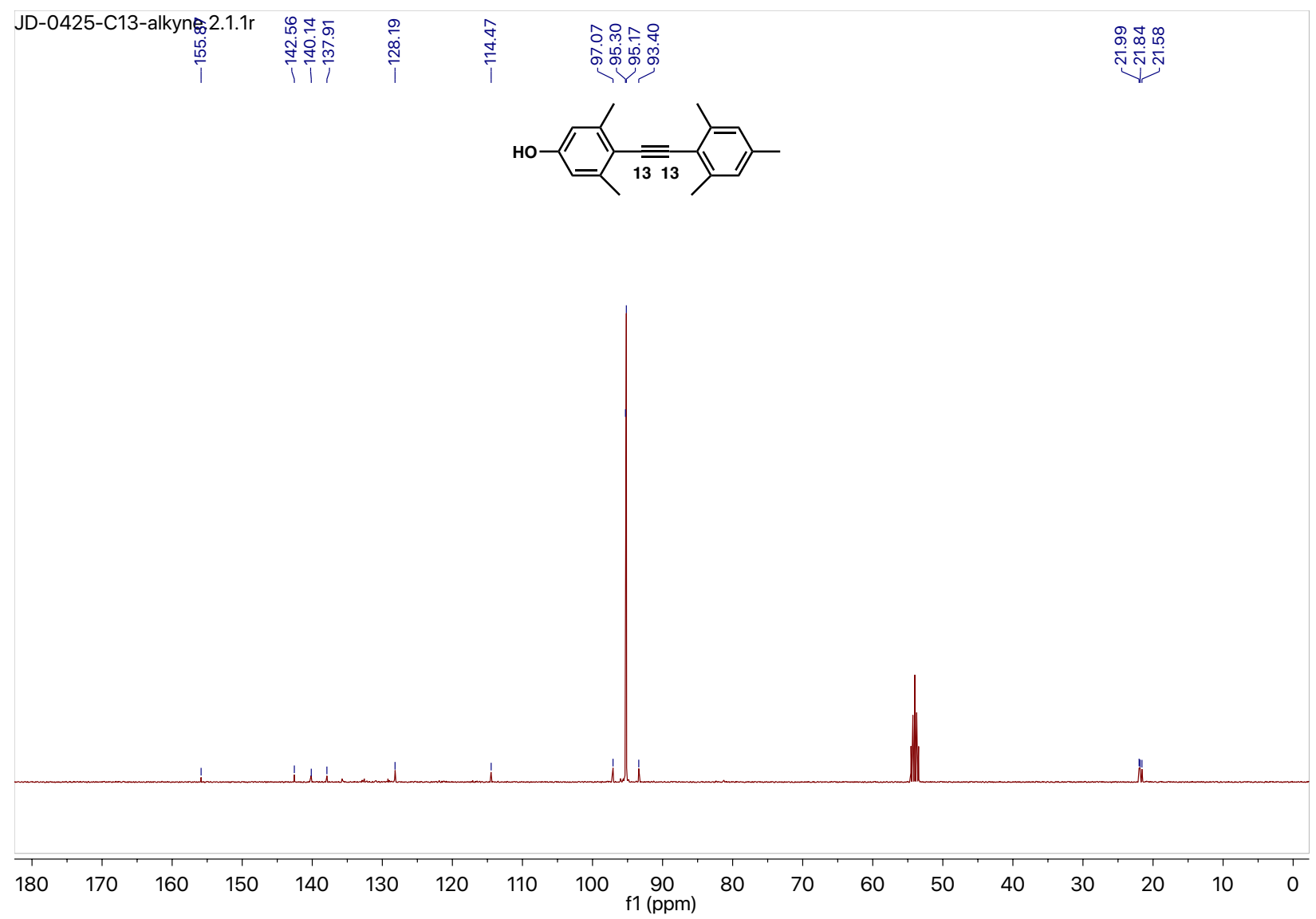

Figure A11. ${ }^{1} \mathrm{H}$ NMR (400 MHz, $\left.\mathrm{CD}_{2} \mathrm{Cl}_{2}\right)$ and ${ }^{13} \mathrm{C} \mathrm{NMR}\left(400 \mathrm{MHz}, \mathrm{CD}_{2} \mathrm{Cl}_{2}\right)$ spectra of I2. 


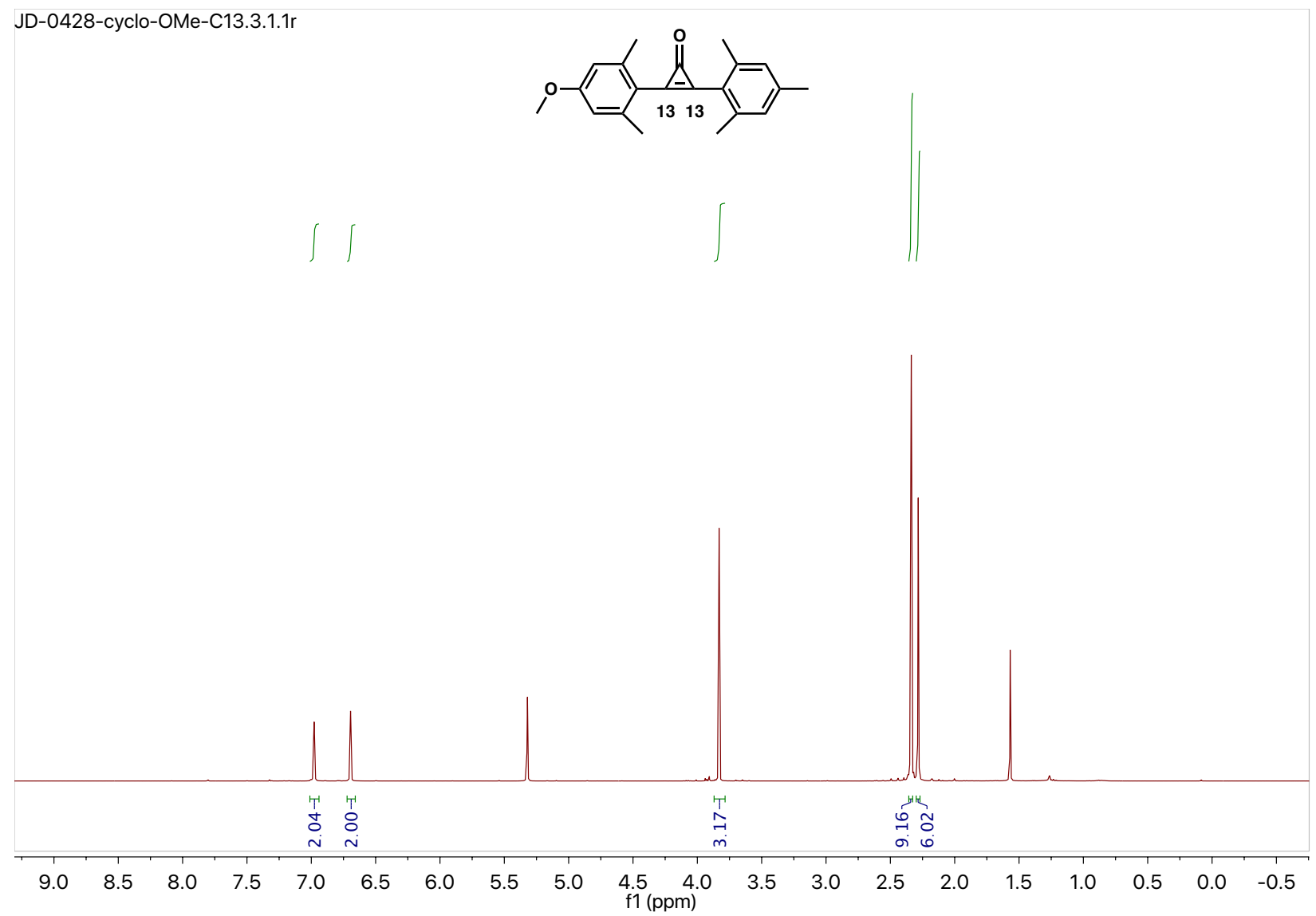




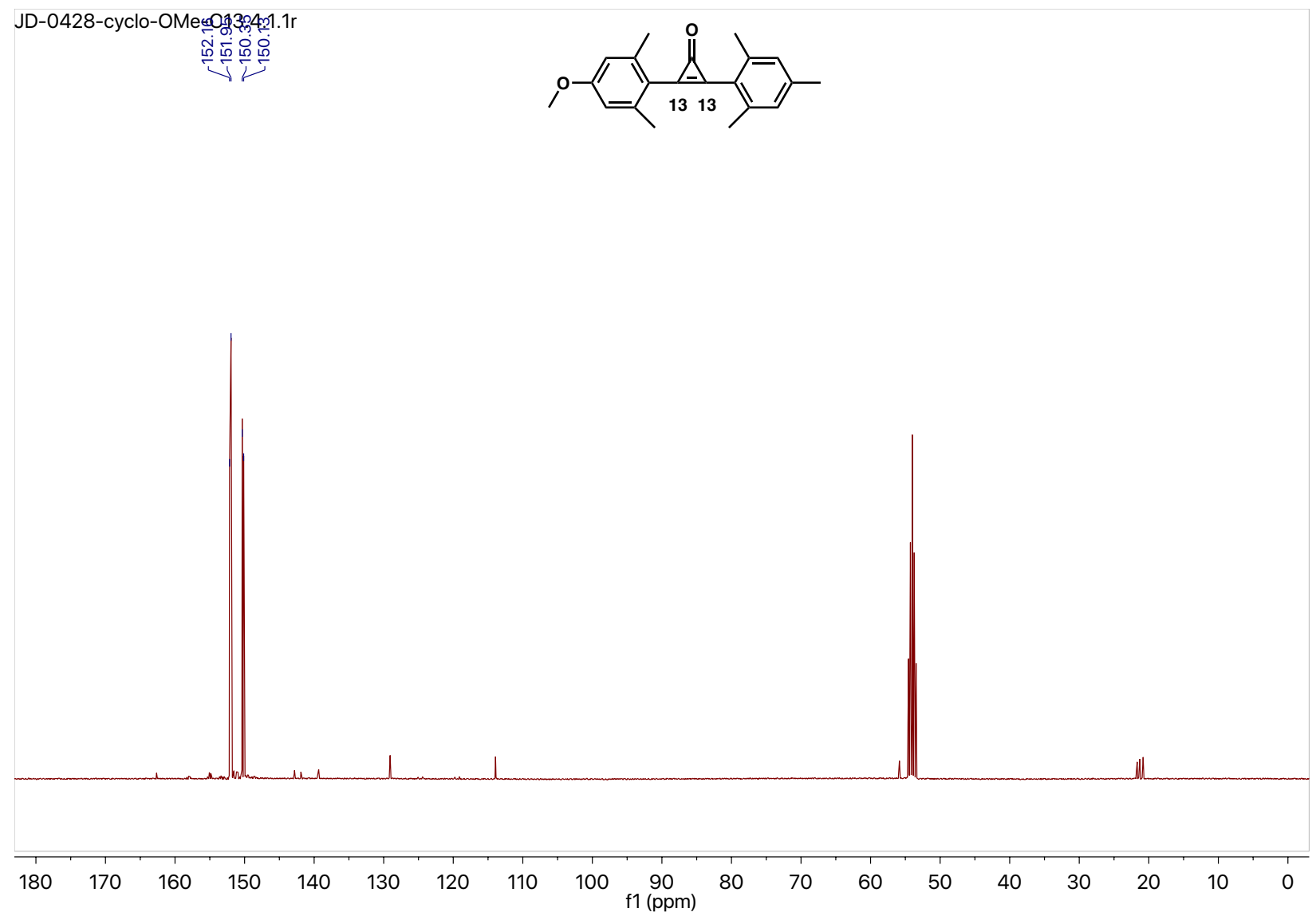

Figure A12. ${ }^{1} \mathrm{H}$ NMR (400 MHz, $\left.\mathrm{CD}_{2} \mathrm{Cl}_{2}\right)$ and ${ }^{13} \mathrm{C} \mathrm{NMR}\left(400 \mathrm{MHz}, \mathrm{CD}_{2} \mathrm{Cl}_{2}\right)$ spectra of I4. 


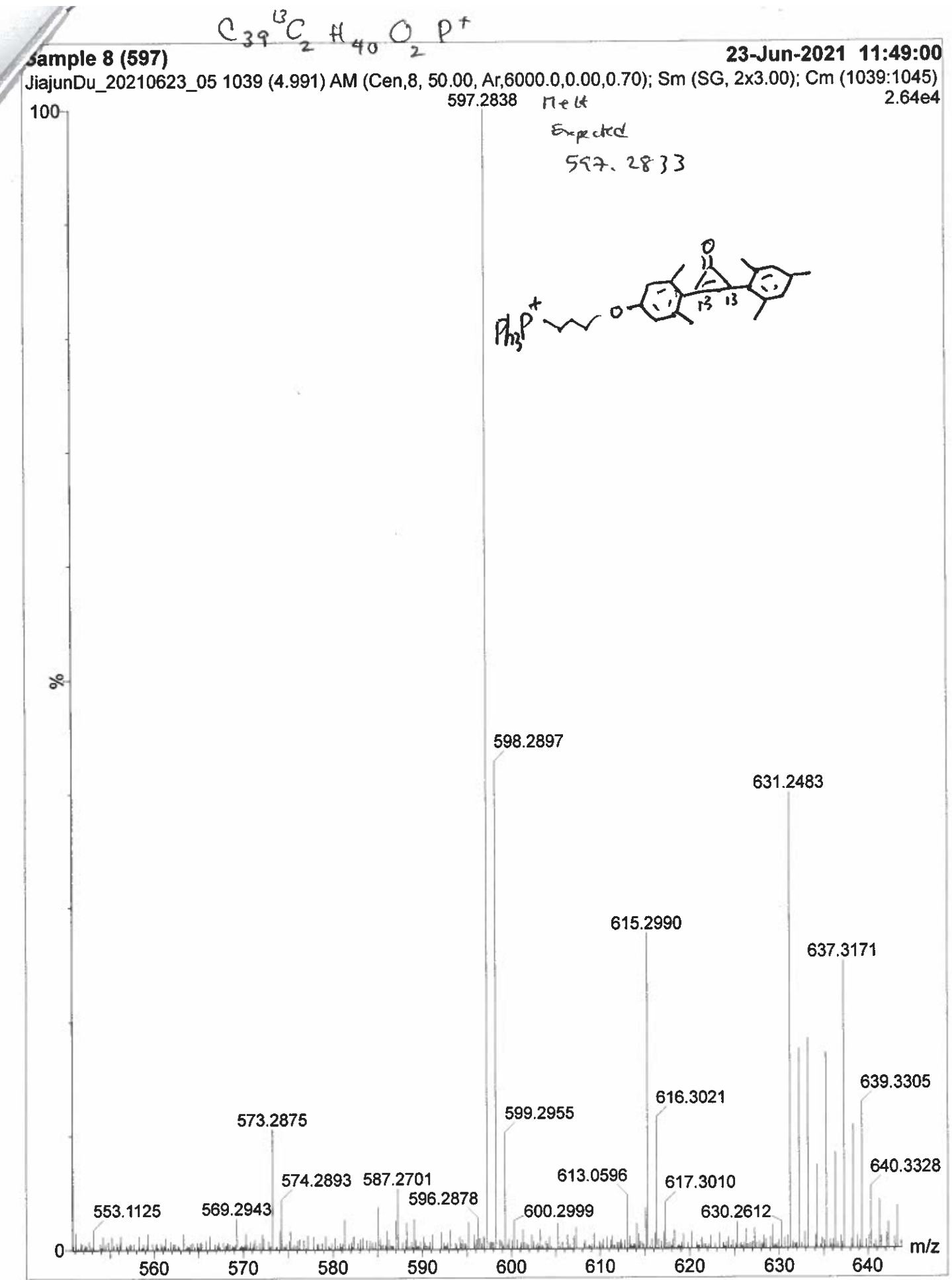




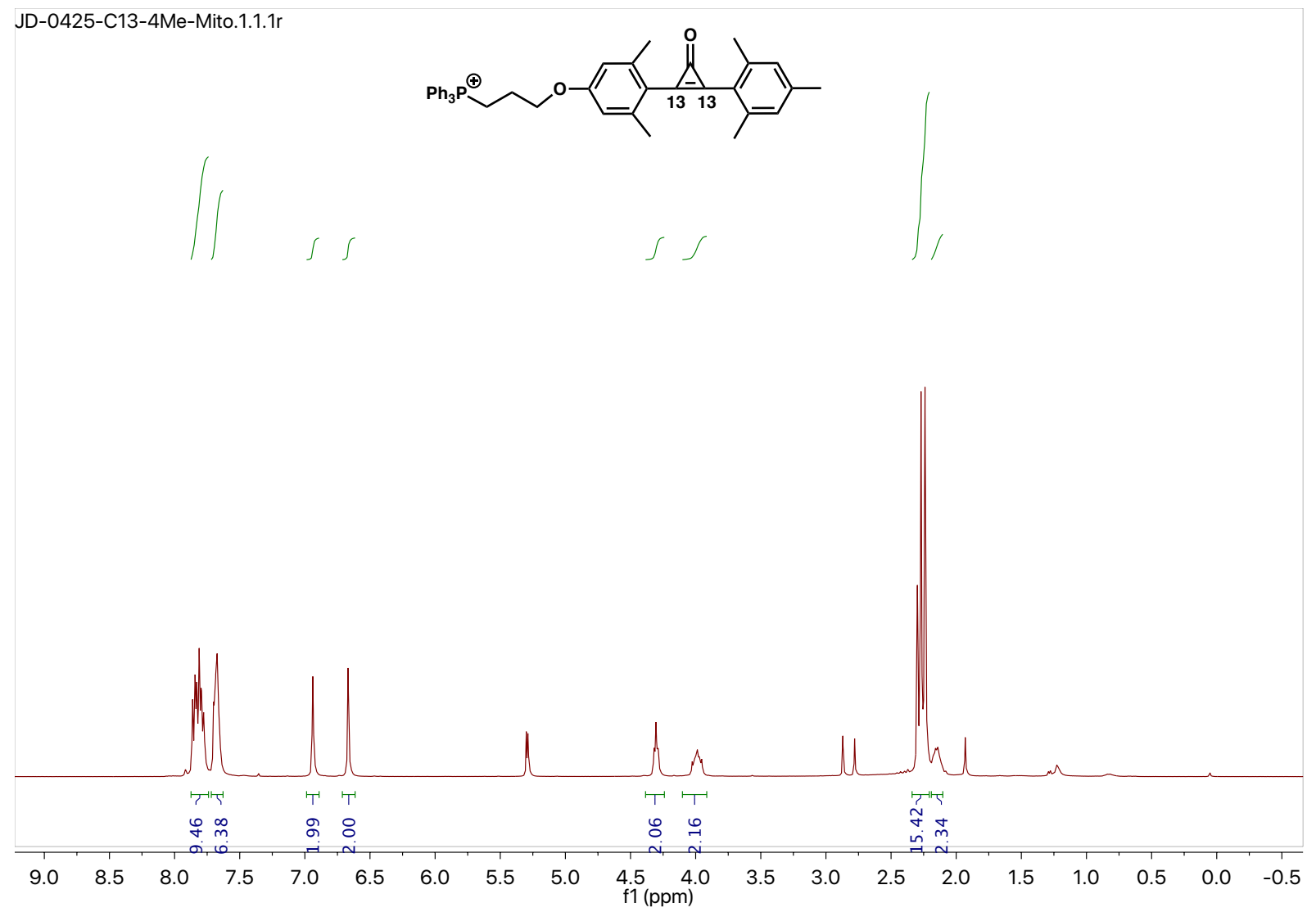




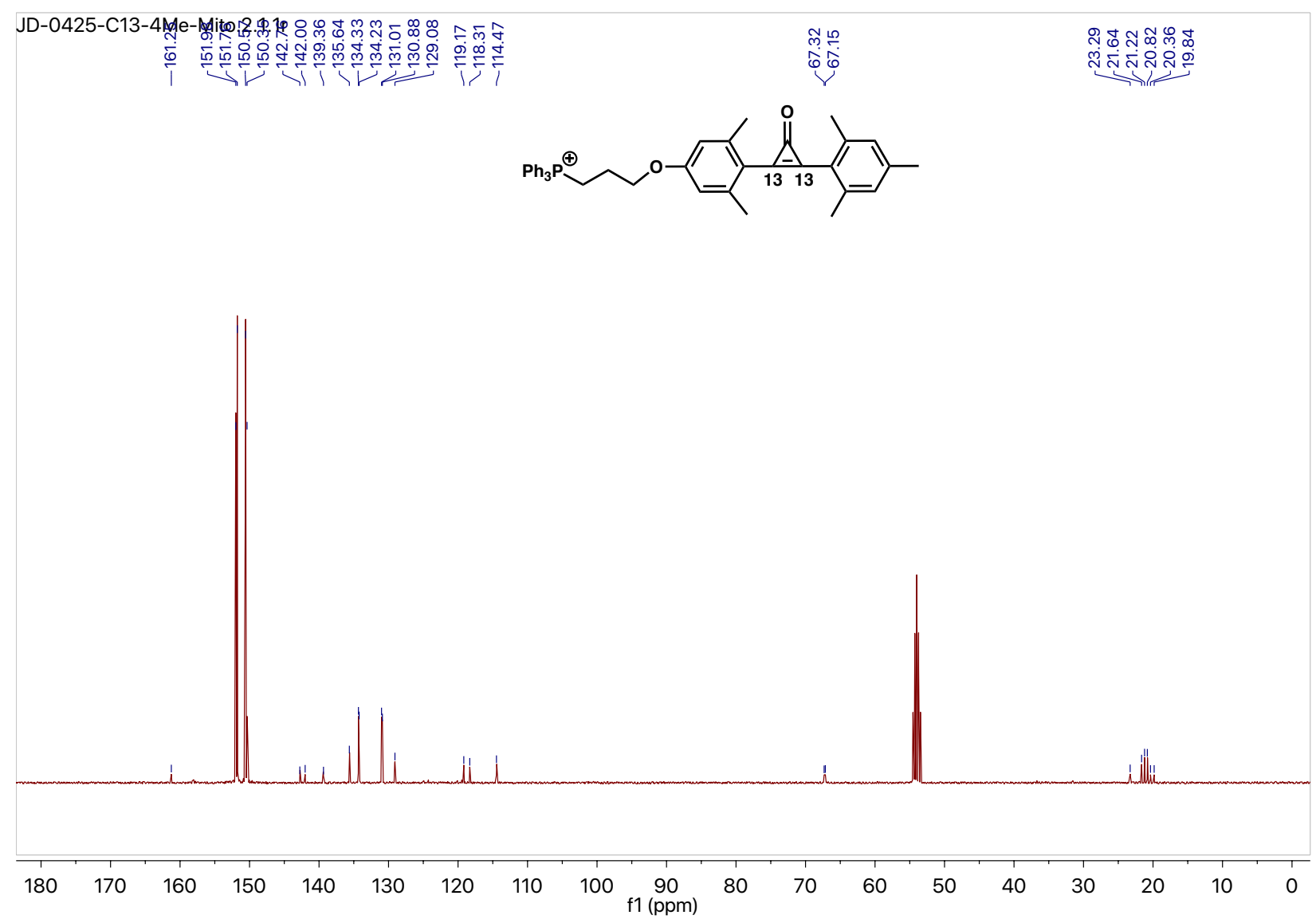

Figure A13. HRMS, ${ }^{1} \mathrm{H} \mathrm{NMR}\left(400 \mathrm{MHz}, \mathrm{CD}_{2} \mathrm{Cl}_{2}\right)$ and ${ }^{13} \mathrm{C} \mathrm{NMR}\left(400 \mathrm{MHz}, \mathrm{CD}_{2} \mathrm{Cl}_{2}\right)$ spectra of Me-Mito- ${ }^{13} \mathrm{C}$ (16). 